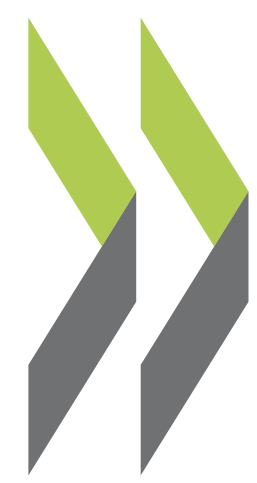

OECD Economics Department Working Papers No. 1629

Boosting productivity in the United Kingdom's service sectors

\section{Annabelle Mourougane,}

Eun Jung Kim 


\section{ECONOMICS DEPARTMENT}

\section{BOOSTING PRODUCTIVITY IN THE UNITED KINGDOM'S SERVICE SECTORS}

\section{ECONOMICS DEPARTMENT WORKING PAPERS No.1629}

By Annabelle Mourougane and Eun Jung Kim

OECD Working Papers should not be reported as representing the official views of the OECD or of its member countries. The opinions expressed and arguments employed are those of the authors.

Authorised for publication by Isabell Koske, Deputy Director, Country Studies Branch, Economics Department.

All Economics Department Working Papers are available at ww.oecd.org/eco/workingpapers.

JT03468632 
OECD Working Papers should not be reported as representing the official views of the OECD or of its member countries. The opinions expressed and arguments employed are those of the author(s).

Working Papers describe preliminary results or research in progress by the author(s) and are published to stimulate discussion on a broad range of issues on which the OECD works.

Comments on Working Papers are welcomed, and may be sent to the Economics Department, OECD, 2 rue André-Pascal, 75775 Paris Cedex 16, France, or by e-mail to econ.contact@oecd.org.

All Economics Department Working Papers are available at www.oecd.org/eco/workingpapers.

This document and any map included herein are without prejudice to the status of or sovereignty over any territory, to the delimitation of international frontiers and boundaries and to the name of any territory, city or area.

The statistical data for Israel are supplied by and under the responsibility of the relevant Israeli authorities. The use of such data by the OECD is without prejudice to the status of the Golan Heights, East Jerusalem and Israeli settlements in the West Bank under the terms of international law.

Note by Turkey

The information in this document with reference to "Cyprus" relates to the southern part of the Island. There is no single authority representing both Turkish and Greek Cypriot people on the Island. Turkey recognises the Turkish Republic of Northern Cyprus (TRNC). Until a lasting and equitable solution is found within the context of the United Nations, Turkey shall preserve its position concerning the "Cyprus issue".

Note by all the European Union Member States of the OECD and the European Union

The Republic of Cyprus is recognised by all members of the United Nations with the exception of Turkey. The information in this document relates to the area under the effective control of the Government of the Republic of Cyprus.

(c) OECD (2020)

You can copy, download or print OECD content for your own use, and you can include excerpts from OECD publications, databases and multimedia products in your own documents, presentations, blogs, websites and teaching materials, provided that suitable acknowledgment of OECD as source and copyright owner is given. All requests for commercial use and translation rights should be submitted to rights@oecd.org 


\section{Abstract/Résumé \\ Boosting productivity in the United Kingdom's service sectors}

The United Kingdom has been among the most affected OECD economies by the COVID-19 crisis, reflecting the high share of services in output and its integration in the world economy. Productivity growth in the United Kingdom has consistently underperformed relative to expectations and was more disappointing than in most other OECD economies since at least the global financial crisis. Sluggish productivity growth in the service sectors was the main factor behind this weak performance. Raising productivity will help to sustain employment and wages but will require a broad range of policies. Keeping low barriers to trade and competition in the UK service sectors will create a supportive environment for strong productivity performance. Prioritising digital infrastructure in the allocation of the planned increase in public investment is expected to bring large productivity dividends. Reviewing the system of support to small firms in the light of the COVID-19 crisis will help to re-prioritise resources towards young innovative firms. Further increasing public spending on training to develop the digital skills of low-qualified workers, which have been particularly affected by the COVID-19 crisis, will be a double-dividend policy, boosting productivity and lowering inequality.

This Working Paper relates to the 2020 OECD Economic Survey of the United Kingdom (http://www.oecd.org/economy/united-kingdom-economic-snapshot/)

Keywords: productivity, United Kingdom, digitalisation, barriers to trade and investment.

JEL Classification: C23, D24, F13

\section{Stimuler la productivité dans les secteurs des services du Royaume-Uni}

Le Royaume-Uni a été parmi les économies de I'OCDE les plus touchées par la crise du COVID-19, reflétant la part élevée des services dans la production et son intégration dans l'économie mondiale. La croissance de la productivité au Royaume-Uni a constamment déçu par rapport aux attentes et a été plus faible que dans la plupart des autres économies de l'OCDE depuis au moins la crise financière mondiale. La croissance limitée de la productivité dans les secteurs des services a été le principal facteur à l'origine de cette faible performance. Augmenter la productivité contribuera à maintenir l'emploi et les salaires, mais exigera un large éventail de politiques. Le maintien de faibles barrières au commerce et à la concurrence dans les secteurs des services britanniques créera un environnement propice à de solides performances de productivité. Donner la priorité aux infrastructures numériques dans l'allocation de l'augmentation prévue des investissements publics devrait apporter d'importants gains de productivité. La révision du système de soutien aux petites entreprises à la lumière de la crise du COVID-19 aidera à redéfinir la priorité des ressources vers les jeunes entreprises innovantes. L'augmentation supplémentaire des dépenses publiques de formation pour développer les compétences numériques des travailleurs peu qualifiés, qui ont été particulièrement touchés par la crise du COVID-19, constituera une politique à double dividende, stimulant la productivité et réduisant les inégalités.

Ce Document de travail a trait à l'Étude économique de l'OCDE du Royaume Uni 2020 (http://www.oecd.org/fr/economie/royaume-uni-en-un-coup-d-oeil/)

Mots Clefs: productivité, Royaume-Uni, digitalisation, barrières au commerce et à l'investissement.

Classification JEL : C23, D24, F13 


\section{Table of contents}

Boosting productivity in the United Kingdom's service sectors $\quad 6$

Introduction $\quad 6$

A rebound in productivity in the service sectors is key to supporting a sustainable recovery 6

$\begin{array}{lr}\text { Productivity performance has been poor since the financial crisis } & 7\end{array}$

$\begin{array}{lr}\text { Productivity has been lacklustre in the service sectors } & 10\end{array}$

Productivity in the service sector needs to accelerate markedly 17

Low investment and innovation rates and a lack of knowledge diffusion across firms are the main factors behind the poor productivity performance

A large part of the post-crisis productivity shortfall reflects low investment and slower innovation

A large tail of less productive firms accounts for much of the productivity shortfall in services 19

How to encourage firms to adopt new technologies $\quad 21$

Some firms are not engaging in the most advanced technologies 22

\begin{tabular}{ll} 
Facilitating access to digital infrastructure & 25 \\
\hline
\end{tabular}

Improving Research and Development support $\quad 26$

Easing access to finance of new and young firms $\quad 28$

Maintaining low barriers to trade and competition 32

Ensuring basic skills in a modern workplace after the COVID-19 crisis 38

Retraining low-skilled workers is a double dividend policy following COVID-19 38

Upgrading management skills will improve the capability of firms to benefit from digitalisation 43

Improving efficiency in the public sector $\quad 45$

Productivity growth in the public sector has improved since the beginning of the decade $\quad 45$

$\begin{array}{ll}\text { Further developing digital government } & 46\end{array}$

$\begin{array}{ll}\text { Bibliography } & 50\end{array}$

\section{Tables}

Table 1. Productivity gaps between UK exporting and non-exporting firms 32

Table 2. Long-run determinants of productivity growth 33

Table 3. Moving from EU to non-EU in restrictions to service trade would reduce long-term productivity in the service sectors

\section{Figures}

Figure 1. Transport and tourism were hit severely by the COVID-19 crisis $\quad 7$

Figure 2. Productivity growth was weaker after the financial crisis than in earlier recoveries 8

Figure 3. Productivity has fallen short in OECD countries since the financial crisis 9

Figure 4. The productivity gap with the United States is large 9

Figure 5. The service sector accounts for $80 \%$ of the UK economy 10

Figure 6. Service sectors represent a large share of exports and investment 11

Figure 7. Digital services constitute a large share of service exports 11 
Figure 8. Productivity levels are higher in manufacturing than in services 12

Figure 9. Service sectors account for a large share of the productivity shortfall $\quad 13$

Figure 10. The service sector is heterogeneous $\quad 14$

Figure 11. Productivity has been weak in both financial and non-financial sectors $\quad 15$

Figure 12. Illustrative scenarios on productivity developments in the United Kingdom 17

$\begin{array}{lr}\text { Figure 13. Investment rates in the service sectors are low } & 18\end{array}$

Figure 14. Firm dynamism is relatively high $\quad 20$

Figure 15. The United Kingdom displays a long tail of low-productivity firms 21

Figure 16. The productivity gap between leader and laggard firms is higher in the United Kingdom 21

Figure 17. Adoption of new technology lags the best performers 22

Figure 18. A range of policies can support productivity through digital adoption in the United Kingdom 24

Figure 19. The share of firms with high-speed broadband is lower than in peer countries 25

Figure 20. Most major investment projects are in transport, energy and utilities 26

Figure 21. Spending on research and development is lower than the OECD average 27

Figure 22. Small firms only receive a limited share of support $\quad 28$

Figure 23. Reliance on venture capital is relatively low $\quad 29$

Figure 24. The pensions market is large $\quad 30$

Figure 25. Equity capital is a small portion of SME finance in the United Kingdom 31

Figure 26. Restrictions on trade in service sectors will rise when the United Kingdom leaves the EU Single
Market

Figure 27. Restrictions to trade in digital services are currently low in the United Kingdom 35

Figure 28. Basic skills are lacking amongst applicants to new position $\quad 39$

Figure 29. The share of jobs at risk is lower in the United Kingdom than in most countries but sizeable $\quad 39$

$\begin{array}{ll}\text { Figure 30. Participation in lifelong learning has declined } & 41\end{array}$

Figure 31. Low-skilled workers receive less firm-based training $\quad 41$

Figure 32. Own-account workers participate less in training $\quad 42$

$\begin{array}{ll}\text { Figure 33. Management skills can be upgraded further } & 44\end{array}$

Figure 34. Managerial quality tends to be lower in family-owned firms $\quad 45$

Figure 35. Health services contributed the most to productivity growth in the public sector in recent years 46

$\begin{array}{ll}\text { Figure 36. The uptake of digital government services is average } & 47\end{array}$

\section{Boxes}

Box 1. The United Kingdom is a service-based economy $\quad 10$

Box 2. Measuring productivity in the service sectors $\quad 16$

Box 3. Does engaging in new technologies boost productivity? 23

Box 4. Explaining productivity developments: insights from sectoral and firm-level data 33

Box 5. Main recommendations of the Digital Competition Expert Panel 37

Box 6. Adult learning for displaced individuals and those with low skills 43 


\title{
Boosting productivity in the United Kingdom's service sectors
}

\author{
By Annabelle Mourougane and Eun Jung Kim ${ }^{1}$
}

\section{Introduction}

The United Kingdom has been among the most affected OECD economies by the COVID-19 crisis, reflecting the high share of services in output and its integration in the world economy. Lockdowns have had a disproportionate impact on service sectors, especially those where teleworking is less prevalent and face-to-face interactions are needed. Those sectors are also likely to recover only slowly from the easing of containment measures, as their activity will be constrained by distancing and measures to limit the spread of the virus. Firms will also need to adapt to the new trade relationships with the European Union. Growth is likely to be subdued for some time, with potential reallocation across sectors, even with policies in place to reignite growth and support a sustainable recovery.

Raising productivity will help sustain employment and wages. Looking back, productivity performance in the United Kingdom has been disappointing, despite a favourable business environment and flexible labour markets. Productivity growth did not recover after the 2008 financial crisis and the productivity gap with leading OECD countries is large. Sluggish productivity in the service sector has contributed prominently to the lacklustre economy-wide productivity performance and needs to pick up to reinvigorate UK productivity growth. Against this background, raising productivity has been one of the United Kingdom's key priorities and is at the centre of its Industrial Strategy, which has made progress since 2017. Further steps have been taken toward raising productivity in the March 2020 Budget and the Plan for Jobs as part of the response to the COVID-19 crisis.

After putting the recent productivity performance in the United Kingdom into historical and international perspective, this paper identifies areas where potential payoffs from reforms could be large and where policy changes are required to adapt to a new post COVID-19 environment and the fast digitalisation of the economy. It first examines policies to encourage firms to adopt new technologies, by securing funding for projects that facilitate access to digital infrastructure, improving support to R\&D, easing access to finance and keeping low barriers to trade and investment in the service sectors. It then discusses how to ensure basic skills in a modern workplace, before suggesting ways to raise efficiency in the public sector.

\section{A rebound in productivity in the service sectors is key to supporting a sustainable recovery}

Service sectors have been hit severely by the outbreak of the coronavirus and the health measures that were introduced to contain the pandemic. In particular, sectors such as hospitality, retail, tourism, cultural activities and travel, which are less amenable to teleworking, were largely shut down by the containment measures and, in the case of air transport, by the widespread restrictions to international passenger travel (Figure 1). Recognising this, policies have been put in place to cushion the downturn, including targeted measures such as a temporary tax cut on some services and "Eat Out to Help" scheme (OECD, 2020a).

\footnotetext{
${ }^{1}$ The authors work at the OECD Trade and Agriculture Directorate and the Economics Department. The authors are grateful to Mark Baker, Sebastian Barnes, Laurence Boone, Isabell Koske, Patrick Lenain, Alvaro Pereira, Dirk Pilat, Valentine Millot, Stéphane Sorbe and colleagues from the OECD and HMT for useful comments and discussions and to Michelle Ortiz for excellent technical assistance.
} 
The health crisis could linger for months or years and any activity that involves person-to-person engagement is likely to be depressed for a long period of time. It may also be long in air transport, depending on how long passenger travel will be restricted.

\section{Figure 1. Transport and tourism were hit severely by the COVID-19 crisis}

Index 1 January $2019=100$

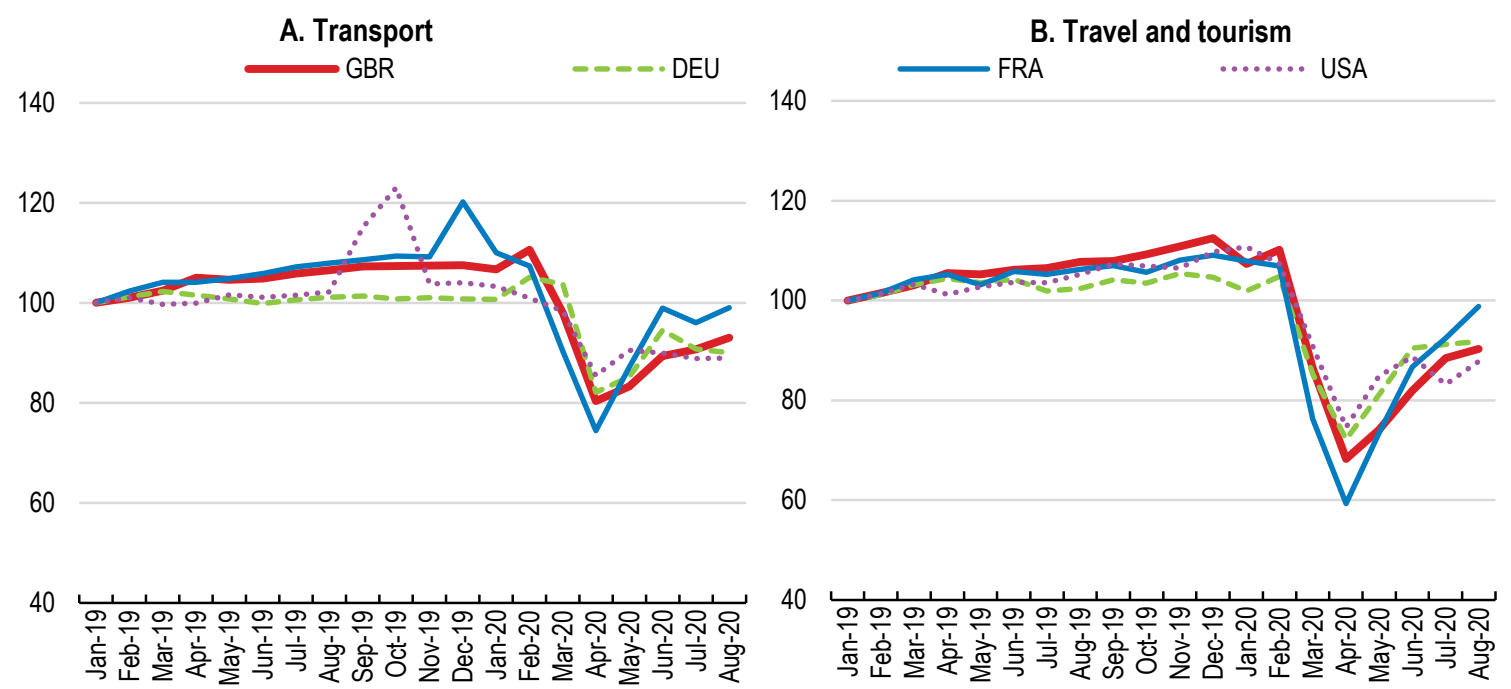

Note: Indicators have been computed using selected categories of Google trends search data.

Source: Gonzales F., A. Jaax and A. Mourougane, "Nowcasting Services Trade", forthcoming.

StatLink त्ञाज https://stat.link/08ur9v

\section{Productivity performance has been poor since the financial crisis}

\section{The post-2008 productivity cycle was unusual}

Productivity growth in the United Kingdom consistently underperformed relative to expectations since at least the global financial crisis. Output per hour stagnated in the post-financial crisis recovery (Figure 2). Poor productivity in the recovery reflected a combination of poor GDP growth on average and sustained employment growth. In the first few years following the financial crisis, the UK economy had reduced working time rather than shedding jobs (Barnett et al., 2014a, OECD, 2019a). Subsequently, labour markets proved quite resilient, with employment growing rapidly and the unemployment rate reaching a record low. However, most additional net jobs created since the crisis were in below-average productivity and wage activities (OECD, 2019a). At the same time, corporate insolvencies were low in the recession that followed the financial crisis (Bryson and Forth, 2015; Riley, Rosazza Bondibene and Young, 2014). This may have entailed inefficient resource allocation and hindered creative destruction, thereby contributing to keep productivity down. But these effects were temporary and firm dynamism, as measured by firm creation and death, recovered after 2012 (OECD, 2019b). Besides those factors, the UK economy has suffered from weak investment and low multi-factor productivity growth, whose slowdown pre-dated the financial crisis (see below). Looking forward, the COVID-19 crisis may have very different implications across sectors and business models with potentially lasting effects through unemployment, firm failures, sectoral reallocation and productivity, although it is too early to provide evidence on the magnitude and the duration of these changes. 
Figure 2. Productivity growth was weaker after the financial crisis than in earlier recoveries

Real output per hour, change from start of recession

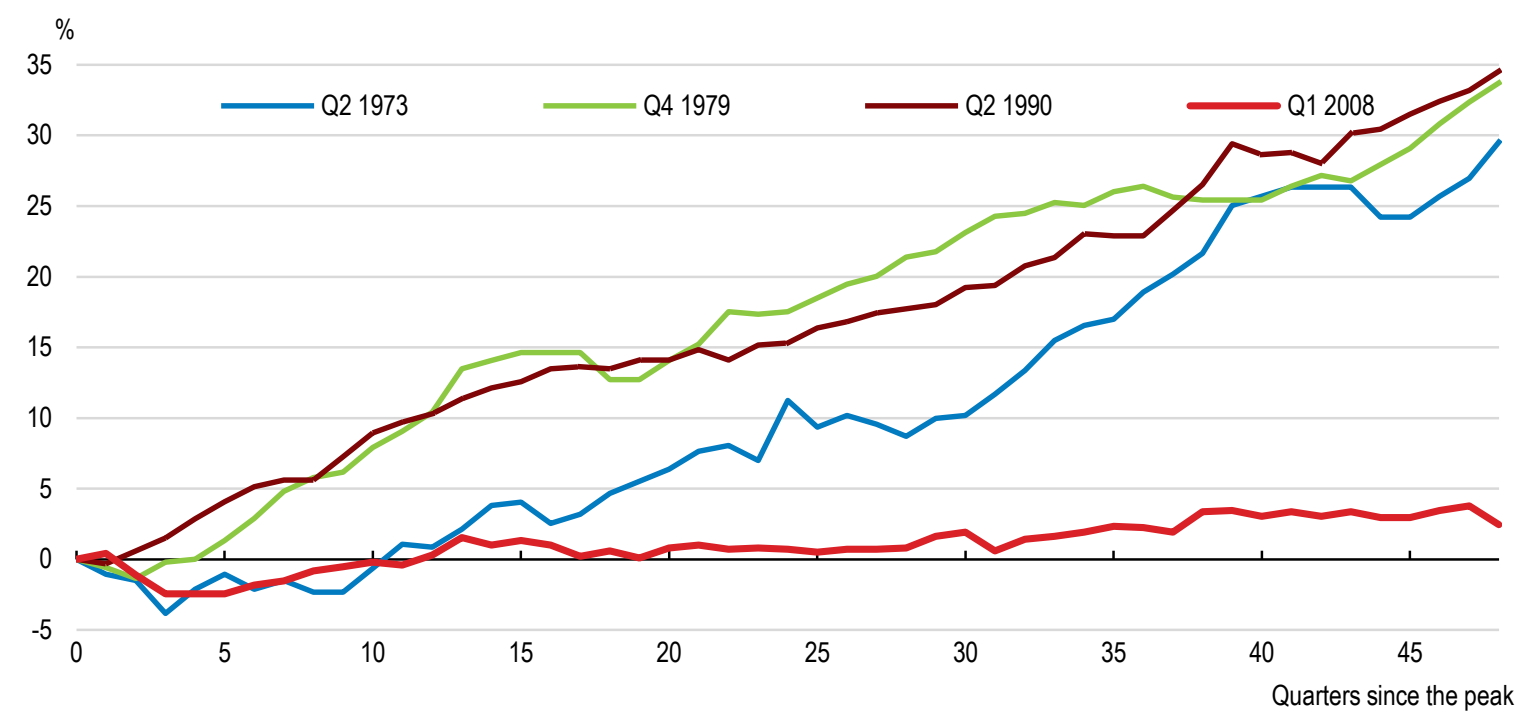

Note: Output refers to real gross value added.

Source: OECD calculations based on ONS (2020), Labour productivity database, July.

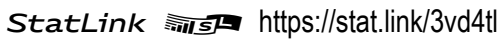

\section{The shortfall in productivity is larger in the United Kingdom than in most OECD countries}

Productivity growth performance in the United Kingdom was more disappointing than in most other OECD economies since the financial crisis, while labour productivity in the United Kingdom grew faster than in most countries from the mid-1990s up to 2008. Productivity growth has been weak in many OECD countries, with the slowdown in productivity often pre-dating the financial crisis (OECD, 2015; 2019a), but there is evidence that the weakness has been more marked in the United Kingdom than in peer countries.

Since the financial crisis, there has been a productivity shortfall between actual productivity levels and the level productivity would have reached had it improved at pre-financial crisis rates in most OECD countries. This shortfall is estimated to be around $10 \%$ on average across OECD countries, but it amounted to $20 \%$ in the United Kingdom in 2019 (Figure 3).

As a result, the UK productivity gap compared to the United States - the productivity leader among large advanced economies - is still large (Figure 4). Historically, comparisons of productivity across countries have shown substantial gaps, even between similar-sized economies at a same stage of development. However, Ward et al. (2018) found that at least a part of these gaps disappears once differences in how countries measure labour input are adjusted for. In the case of the United Kingdom, the gap in labour productivity levels with the United States is around 6.3 percentage points smaller than was previously thought - but nevertheless remains large at around $17.8 \%$. 
Figure 3. Productivity has fallen short in OECD countries since the financial crisis

Deviation of the level of productivity from the pre-crisis trend path, 2019 or latest year

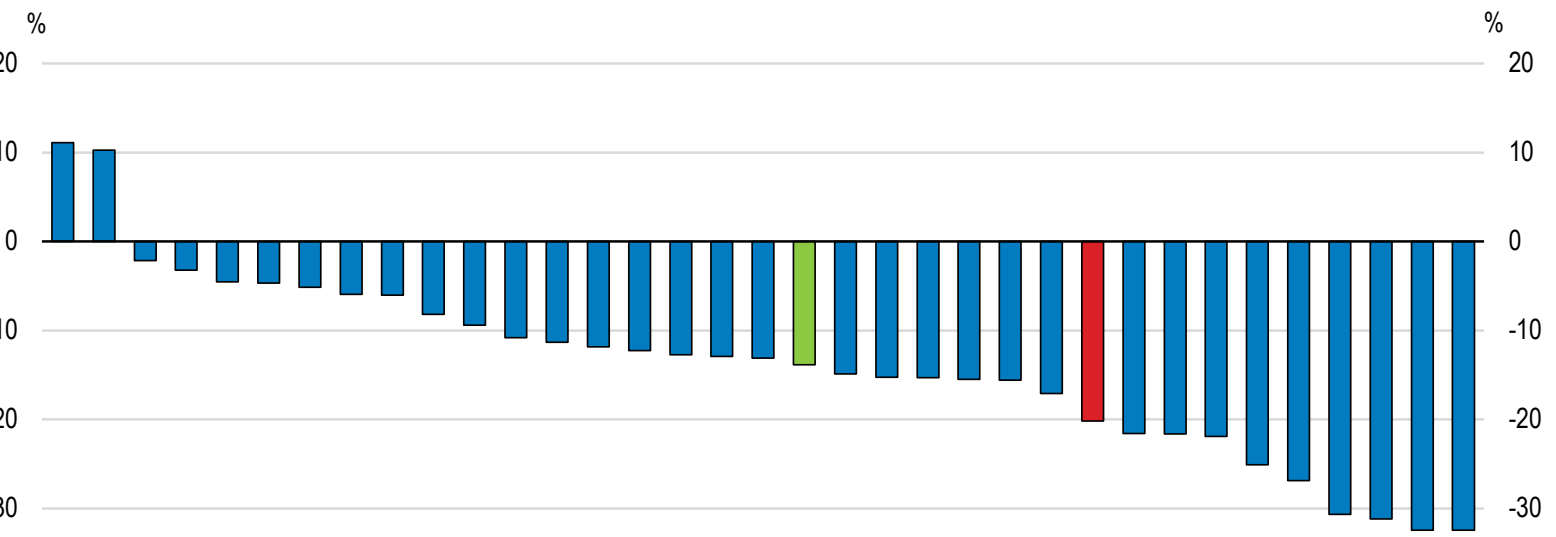

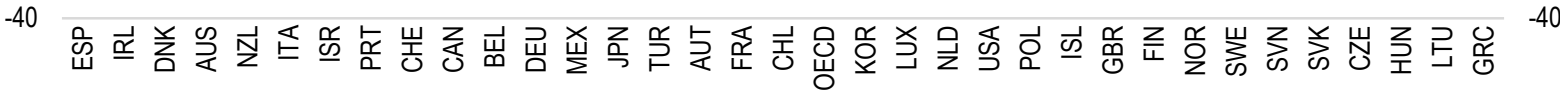

Note: Labour productivity is defined as real gross domestic product (GDP) per hour worked. Pre-crisis trend growth is calculated between 1997 and 2007. The OECD aggregate is calculated as an unweighted average.

Source: OECD calculations based on OECD (2020), OECD Productivity Statistics (database).

StatLink त्ञाIs https://stat.link/k5rzy8

Figure 4. The productivity gap with the United States is large

Gaps in GDP per hour worked, 2016

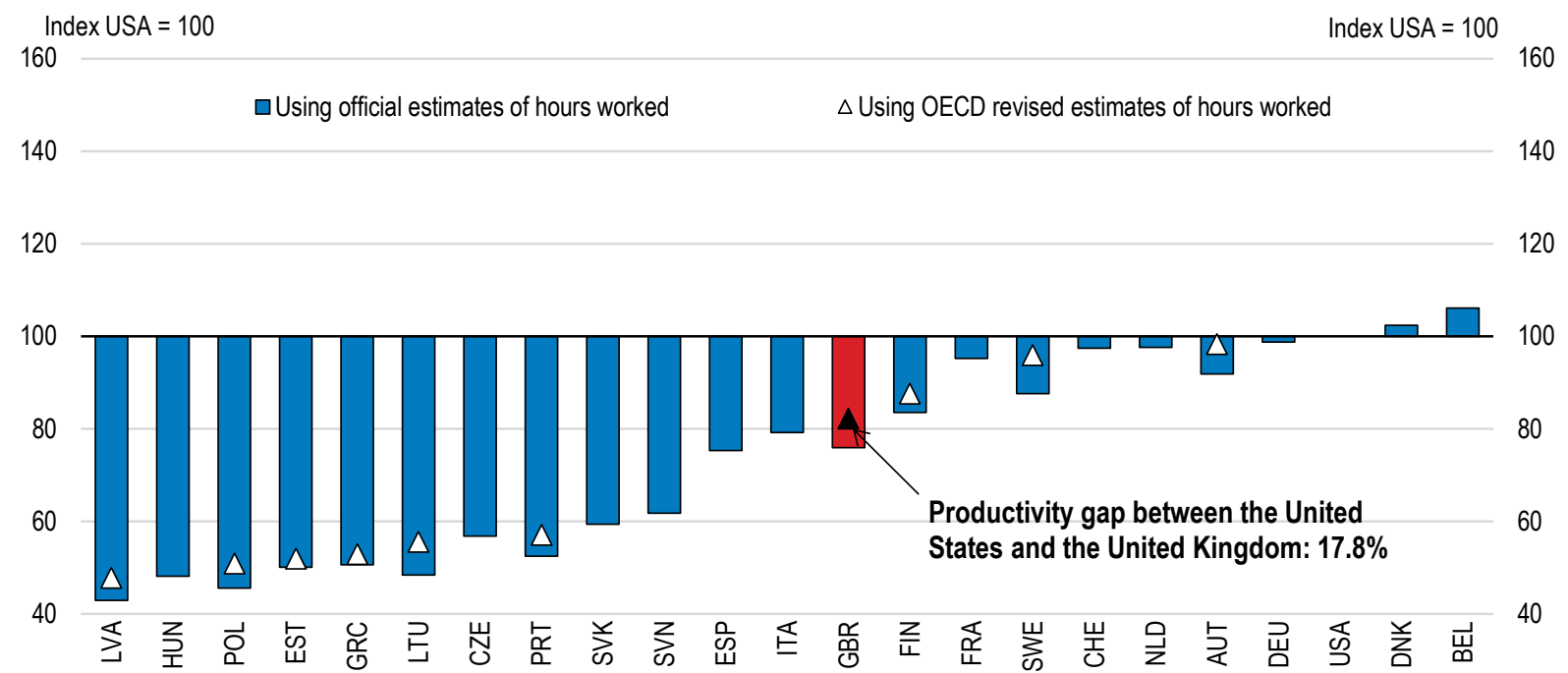

Note: Hours worked are measured using average hours worked from official national accounts and from the OECD labour force survey based simplified component method.

Source: Ward et al. (2018), International productivity gaps: Are labour input measures comparable?, OECD Statistics Working Papers, No. 2018/12. 


\section{Productivity has been lacklustre in the service sectors}

The United Kingdom is overwhelmingly a service-based economy (Box 1). The service sector accounts for a high share of output and employment, close to $80 \%$. This share has stabilised since the financial crisis, reflecting some downsizing in the financial sector. Although those trends are also visible in other OECD countries, the share of the service sector in the United Kingdom remains one of the highest in the OECD countries.

\section{Box 1. The United Kingdom is a service-based economy}

The share of the service sector grew after the financial crisis (Figure 5). It represents about $80 \%$ of the economy both in terms of output and of employment (as compared to around $70 \%$ for employment and production on average in the OECD). Within the service sector, the share of financial services has been trending down to under $10 \%$ in terms of value-added and $4 \%$ in terms of employment. The service sector also plays a significant role in terms of investment, accounting for $64 \%$ of business investment in 2018 (Figure 6). Services represent $45 \%$ of total exports, of which about a third is of financial services. Digital trade has developed fast. At $42.5 \%$, the share of services trade that can be delivered digitally is one of the highest amongst OECD countries (Figure 7). The share of digital exports of financial services is particularly high.

\section{Figure 5. The service sector accounts for $80 \%$ of the UK economy}
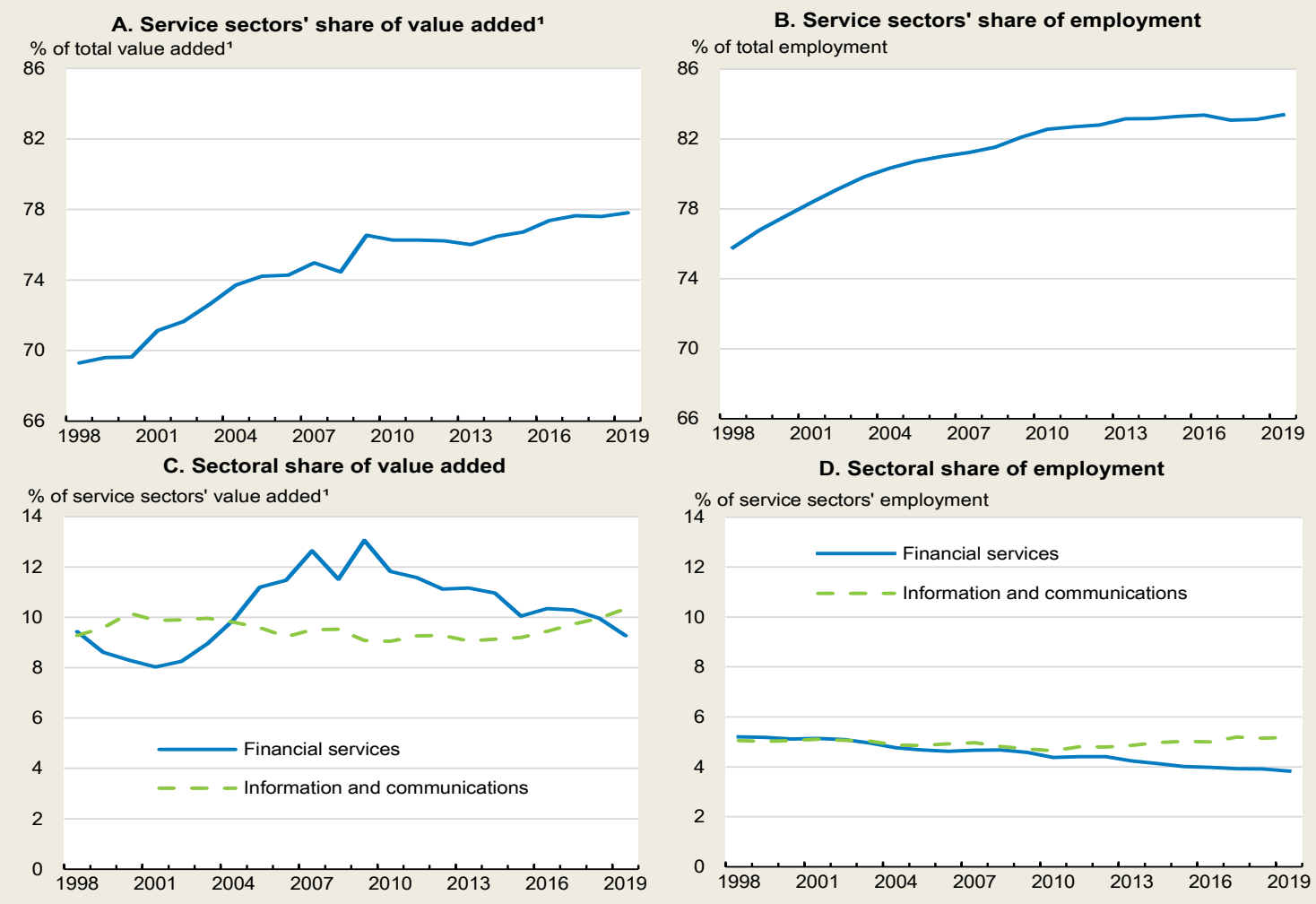

1. Excludes imputed rents. Data refer to nominal gross value added.

Source: ONS (2020), "Quarterly National Accounts: Oct to Dec 2019", and "Productivity jobs, productivity hours, market sector workers, market sector hours", April.

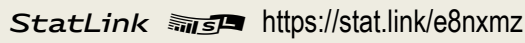


Figure 6. Service sectors represent a large share of exports and investment

\section{A. Share of goods and services in total exports} 2018

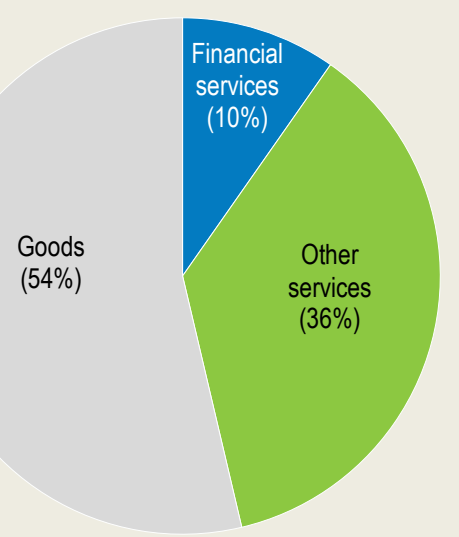

B. Share of business investment by industry ${ }^{1}$ 2018

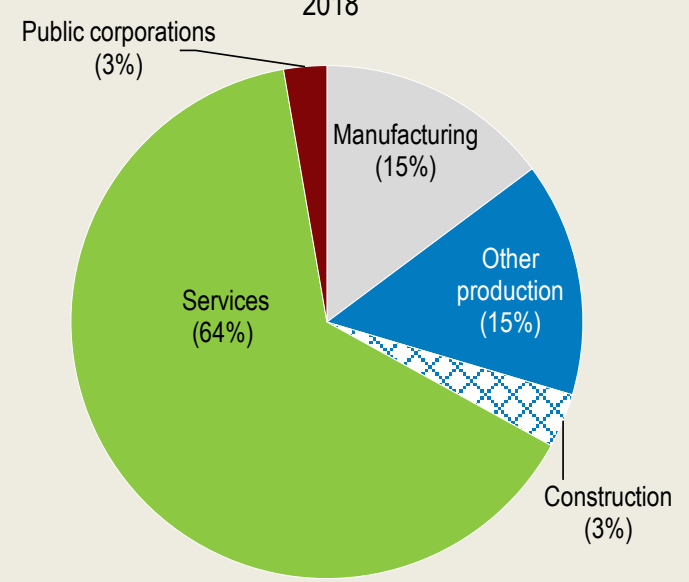

1. Based on nominal gross fixed capital formation.

Source: ONS (2019), "UK Balance of Payments, The Pink Book: 2019" and "Business investment by industry and asset", March.

StatLink त्ञाजा https://stat.link/puyr20

Figure 7. Digital services constitute a large share of service exports

Exports in predominantly digital services, \% of total service exports, 2017

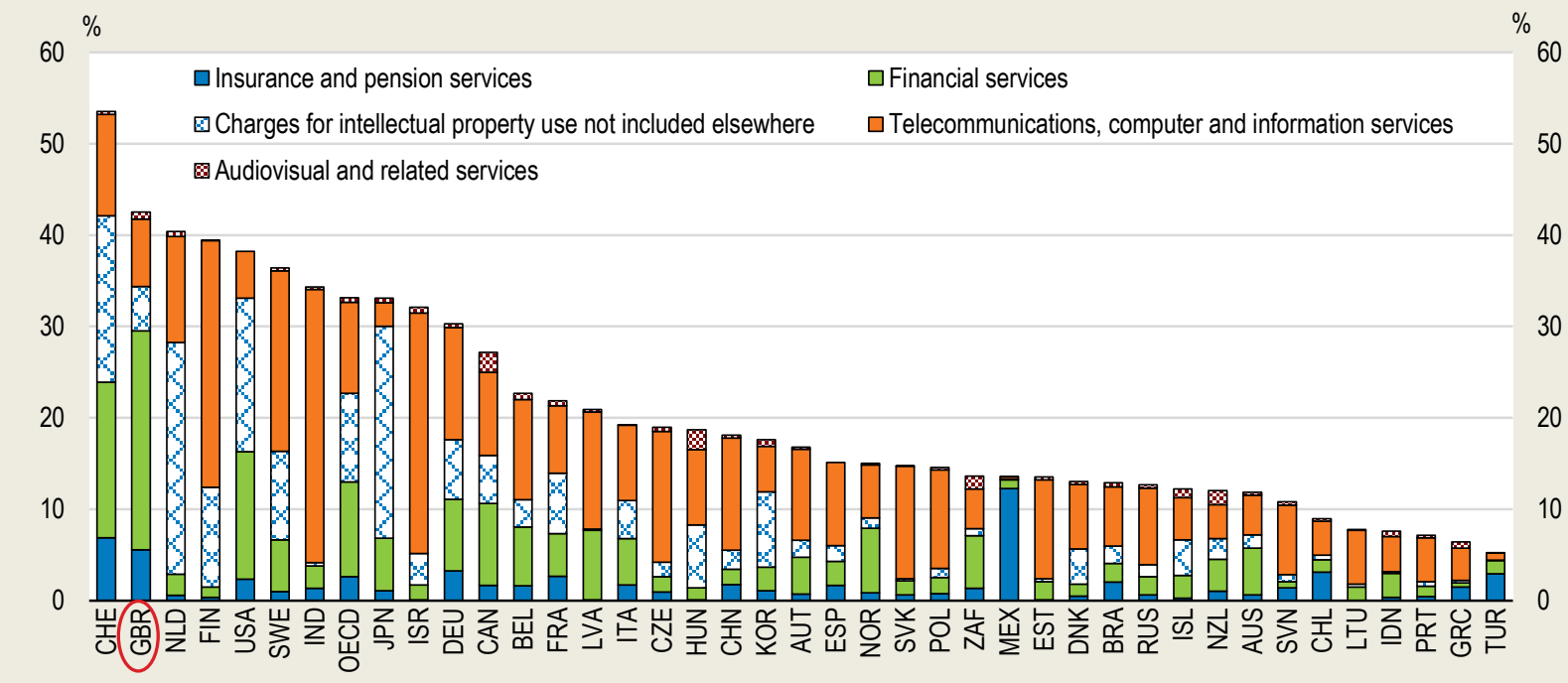

Note: The service sector classification is based on the Extended Balance of Payments Services Classification (EBOPS). For Chile, Mexico, New Zealand, and Switzerland, audiovisual and related services include other personal, cultural, and recreational services.

Source: OECD (2019), Going Digital: Shaping Policies, Improving Lives.

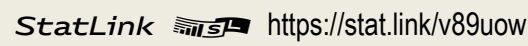


The shift towards service activities explains little of the poor aggregate productivity trends

The sectoral composition of output has implications for productivity, as productivity levels are higher in manufacturing than in services (Figure 8). Levels of productivity in the United Kingdom were $21 \%$ lower in services than in manufacturing in 2019. Indeed services tend to be less standardised than goods and some of them have to be delivered in person, hindering economies of scale and automation. Regulations are also usually more stringent in the service sectors, which can reduce trade in services and erect entry barriers (OECD, 2020b). Smaller productivity level differentials between services and manufacturing were observed in France, Germany and Italy.

\section{Figure 8. Productivity levels are higher in manufacturing than in services}

Real value added per hour worked in GBP

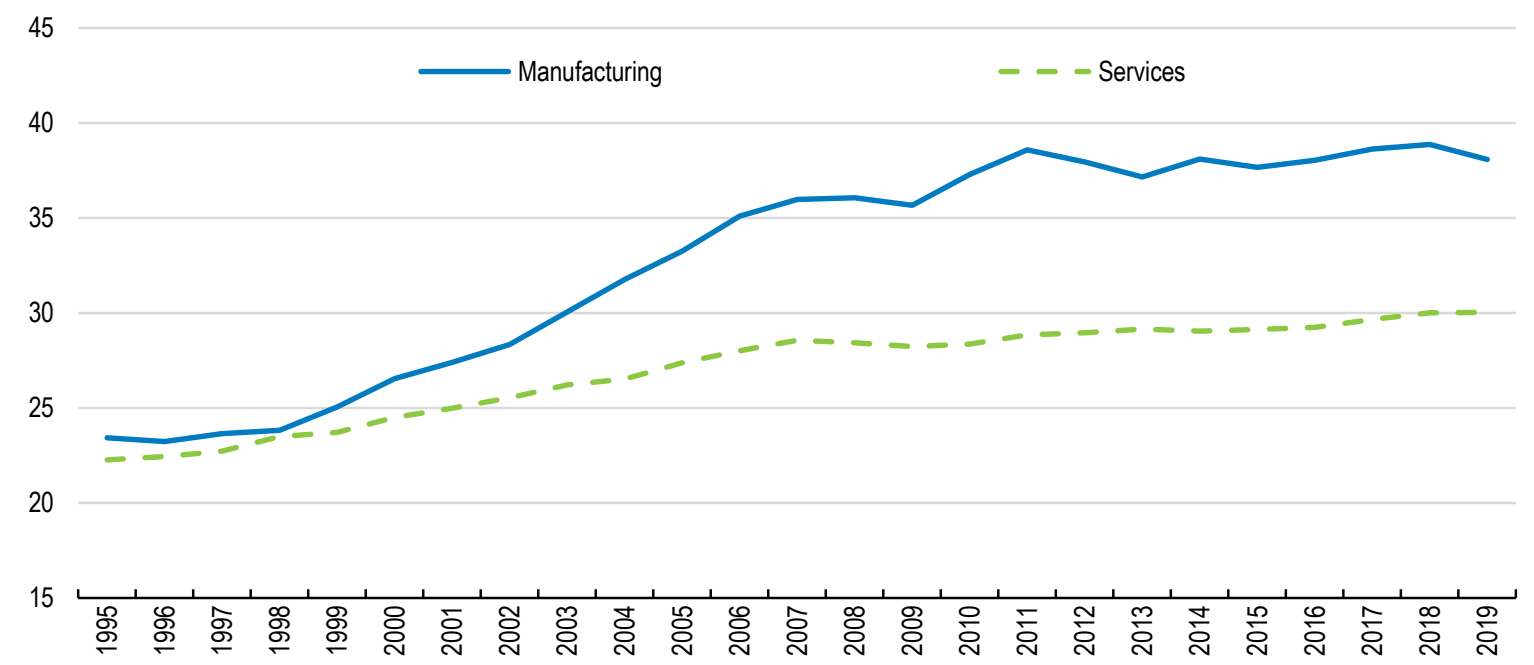

Note: Service sectors' real value added excludes imputed rents. It may be different to official aggregate data due to chain-linking methodology. Source: OECD calculations based on ONS (2020), "GDP output approach - low-level aggregates", May, and "Productivity jobs, productivity hours, market sector workers, market sector hours", April.

StatLink त्राजा https://stat.link/mrpvxe

The sectoral shift to services from manufacturing accounts for a small part of the weakness in productivity in the United Kingdom after the financial crisis: it would explain around 1 percentage point in the productivity shortfall. This is consistent with Barnett et al. (2014b), Haldane (2017), Kierzenkowski et al. (2018), Riley, Rincon-Aznar and Samek (2018) and Sorbe, Gal and Millot (2018). It is comparable to what has been observed in other economies: the reallocation of resources from sectors where productivity growth has been relatively poor would amount to around 1 percentage point of the productivity shortfall after the financial crisis on average across OECD countries.

\section{Weak productivity growth in the service sector has been the main factor behind the poor aggregate performance}

Weak productivity performance in the service sector was the main factor behind weak aggregate productivity growth. The contribution of the service sectors to the productivity shortfall since the financial crisis has been more pronounced in the United Kingdom than in many other OECD countries (Figure 9). Weak service productivity is estimated to account for $59 \%$ of the productivity shortfall since the crisis, as opposed to $24 \%$ on average in OECD countries, reflecting essentially the high weight of the service sector in the UK economy. Productivity is estimated to have grown by $0.6 \%$ on average per year in the United 
Kingdom since 2010 in the services sectors and $1 \%$ in the manufacturing sector. The productivity slowdown in the manufacturing sector contributed less in the United Kingdom than in other OECD countries.

\section{Figure 9. Service sectors account for a large share of the productivity shortfall}
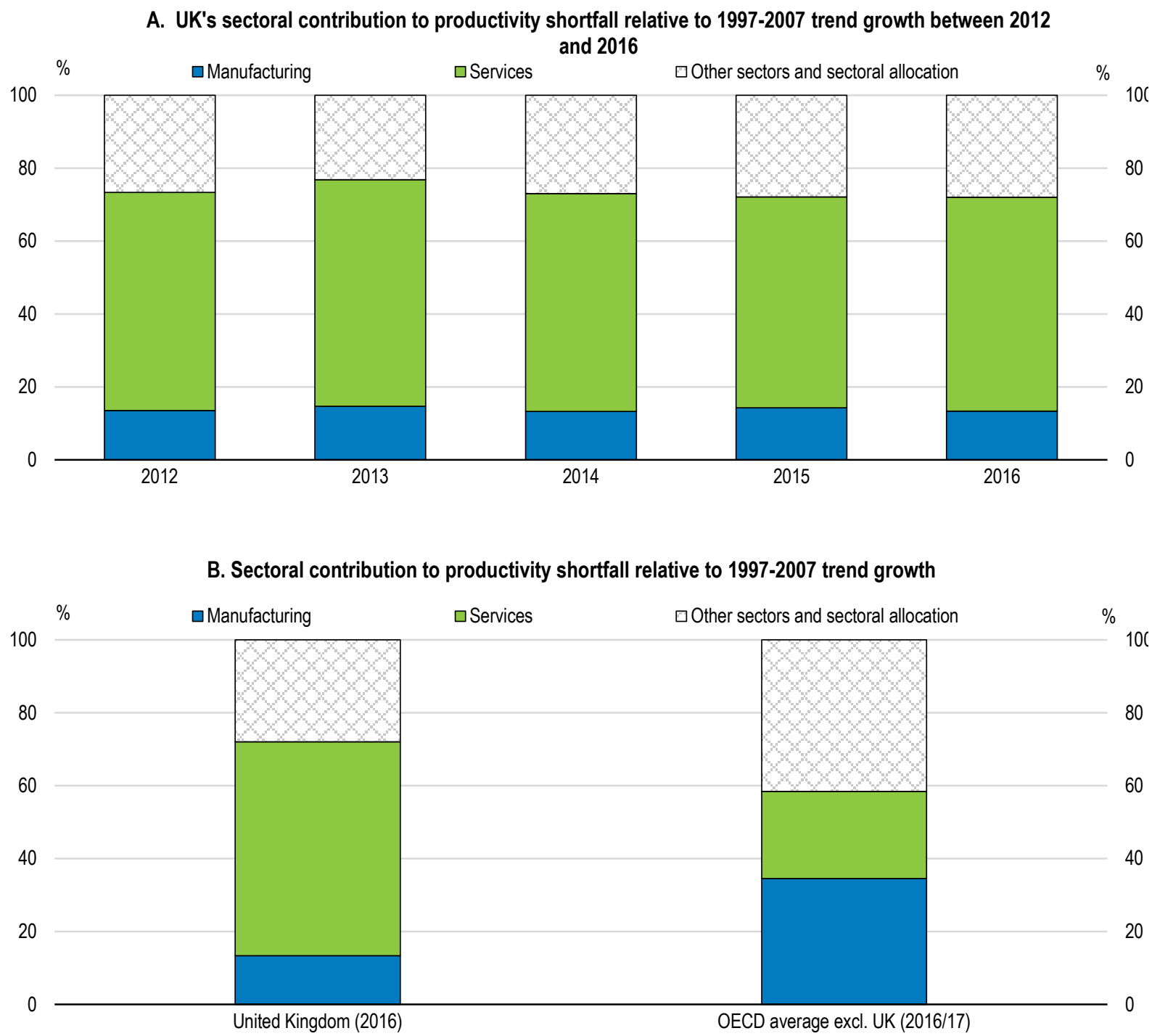

Note: Based on the decomposition formula of shift-share analysis. For the OECD aggregate, unweighted average of 19 countries excluding the United Kingdom.

Source: OECD calculations based on OECD (2019), OECD National Accounts Statistics (database) and OECD Structural Analysis Database (STAN).

StatLink ज्ञाIs https://stat.link/voreuy

\section{All service sectors experienced poor productivity growth}

The service sector is very heterogeneous and categories within the sector display different productivity levels (Figure 10). Some low-productivity categories such as retail sales involve a higher share of routine tasks, which are currently far from automated and generally performed by low- or middle-skilled workers. By contrast, knowledge-intensive services such as financial services and information and technology experience higher productivity levels, as they employ high-skilled workers and can more easily benefit from 
economies of scale, capital deepening and knowledge spillovers (Sorbe et al., 2019). The lowerproductivity activities are more likely to have been impacted negatively by the COVID-19 crisis as they are more reliant on face-to-face operations and less able to use technology to continue producing.

\section{Figure 10. The service sector is heterogeneous}

Real value added per hour worked in GBP, 2019

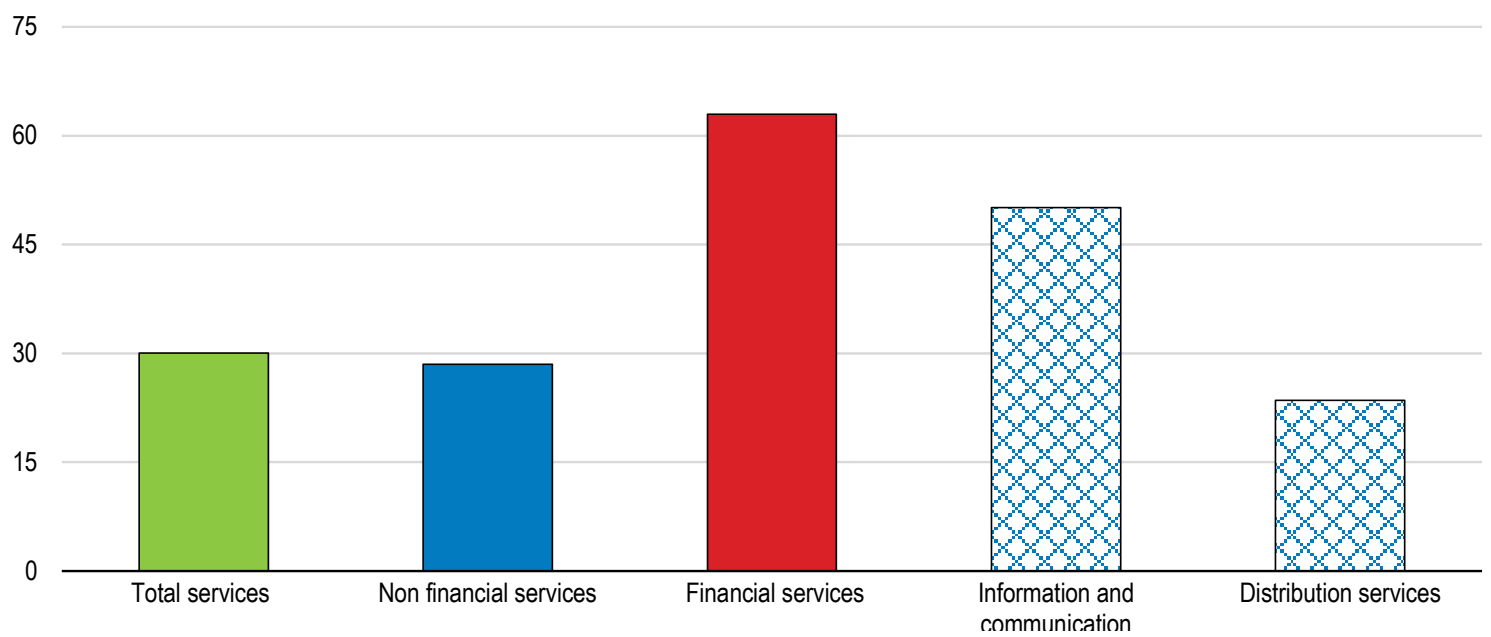

Note: Overall service sectors' real value added is computed by aggregating individual service sectors. It excludes imputed rents. Source: OECD calculations based on ONS (2020), "GDP output approach - low-level aggregates", May, and "Productivity jobs, productivity hours, market sector workers, market sector hours", April.

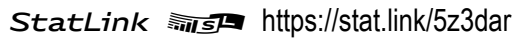

In the period since the financial crisis, most service sectors experienced weak productivity growth, distribution being an exception (Figure 11). Sectors which experienced a more pronounced slowdown in productivity, such as the financial and information and technology sectors, are also those where productivity is hardest to measure (Box 2). Failure to account for intangible capital or the difficulty to price rapid quality improvements, in particular for digital products, have often been put forward as a source of underestimation of productivity growth. Mismeasurements are, however, unlikely to be the main explanation of poor productivity performance in most sectors (Byrne, Fernald and Reinsdorf, 2016; Syverson, 2017; Ahmad, Ribarsky and Reinsdorf, 2017).

Both financial and non-financial sectors were major contributors to the productivity shortfall (relative to precrisis trend productivity growth). The main drag to productivity in the United Kingdom was the financial and the ICT sectors. In these two sectors, the contribution to the productivity shortfall was much more pronounced than in the average of OECD countries (Figure 11).

Despite the rapid pace of technological advancements in recent years, productivity in the ICT sector, which accounted for $8.1 \%$ of total value-added (excluding imputed rent) in 2019 , is estimated to have grown more slowly in the decade since the financial crisis than in any other period since World War Two. This coincided with a gradual decline in investment rates in the ICT sectors. Eurostat data point to a decline in the investment rate in that sector from $22 \%$ of GDP in 2000 to only $12 \%$ in 2018 , part of it reflecting price effects. Investment as a share of value added in intangible assets also markedly declined in the ICT sector (ONS, 2018a).

Productivity growth in the financial services sector slowed markedly after the financial crisis from $7.8 \%$ on average per year during the period $1998-2008$ to $2.9 \%$ from 2009 to 2017 . The apparent slowdown in productivity growth partly reflects an unusually high measured productivity growth prior to the crisis, driven 
by higher leverage and risk-taking within financial firms. The scaling back of these activities since the crisis is a welcome development in terms of stability but may have stifled measured productivity, a development that may have been entrenched by the move to international standard agreed in Basel III through increasing lending rates and dampening investment activity (Brooke et al., 2015). Despite these trends, financial services productivity is twice as high as overall productivity across the United Kingdom (Bardalai, 2019).

Figure 11. Productivity has been weak in both financial and non-financial sectors

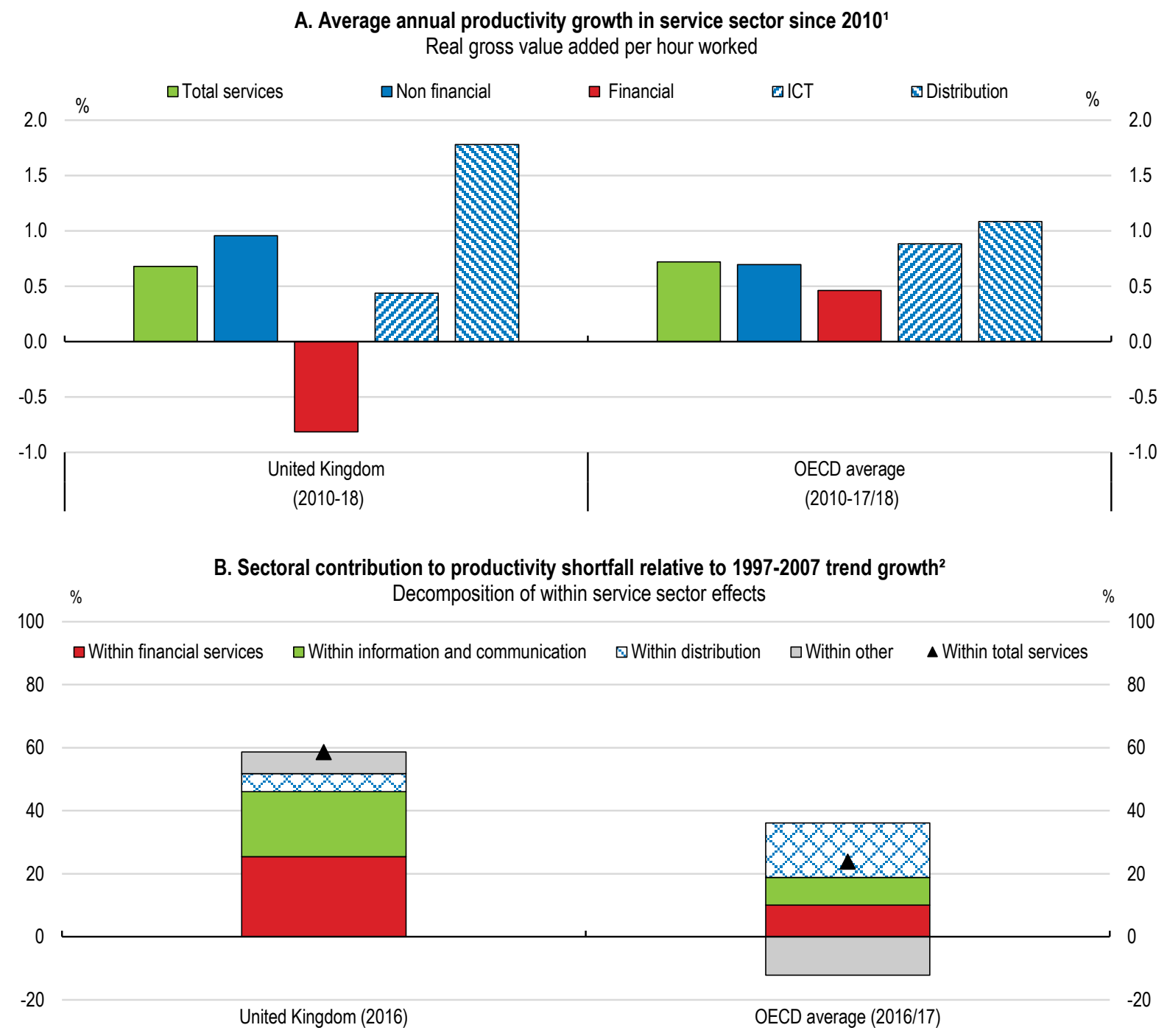

1. Service sectors' value added excludes imputed rents.

2. Based on the decomposition formula of shift-share analysis. The OECD aggregate is the unweighted average of 19 countries excluding the United Kingdom.

Source: OECD calculations based on ONS (2019), "GDP output approach - low-level aggregates", May and "Productivity jobs, productivity hours, market sector workers, market sector hours", April; OECD (2019), OECD National Accounts Statistics (database) and OECD Structural Analysis Database (STAN).

StatLink त्गाs https://stat.link/wqzk4t

Productivity in real estate has also performed poorly since the financial crisis, with productivity growth being more negative in the real estate sector before than after the crisis. This holds whether imputed 
housing rents are included or not in gross value added in the United Kingdom. However, because such a correction cannot be easily undertaken on a cross-country basis, it is difficult to compare productivity developments in the real estate sector in the United Kingdom with those in other countries.

Productivity growth in the UK retail sector appears to have outperformed other OECD countries in the years after the financial crisis. Compared to other key sectors, the retail sector had the lowest average level of labour productivity since 2009 , but the highest average labour productivity growth rate. The faster labour productivity growth rate from 2009-14 may reflect firms making use of opportunities for increased automation in supply chain management and logistics as well as in customer-facing roles (Institute for Employment Studies, 2016). It could also be related to higher ICT use.

\section{Box 2. Measuring productivity in the service sectors}

\section{Productivity measurement is more challenging in services than in other sectors}

Productivity is notoriously difficult to measure. Difficulties are compounded by the development of the digital economy, which has given rise to new products and rapid quality improvements, potentially resulting in overestimated inflation and, in turn, underestimated real output.

Measurement issues are more challenging in the service sector. The intangible nature of much of service output, which often involves human interactions between providers and consumers, implies that transactions can be heterogeneous and their exact nature ambiguous, creating difficulties to disentangle quality from quantity and to effectively price units of service output (Griliches, 1992; Triplett and Bosworth, 2003; Wölfl, 2005; Grassano and Savona, 2014). To address this issue, statistical agencies use various pricing methods of market services (direct use of prices of repeated services, unit value method, component pricing method, percentage fees, model pricing, pricing based on working time).

\section{Measurement is even more challenging for services where there is no market price...}

Due to the lack of data, the value of real output in some public services is assumed in many countries to be equal to the value of inputs, resulting in zero productivity growth.

ONS publishes alternative measures of productivity for the public services following the framework set out in the Atkinson Review (2005). These estimates use a basket of activities measuring the quantity and in turn the value of 'output' directly rather than through a sum of costs approach. Baskets vary by service area. For example, for healthcare it may include number of operations, number of patients, number of GP appointments, number of dental check-ups, and so on (Center for Health Economics, 2019). Where possible, these outputs are quality-adjusted to reflect the changing quality of the output being provided (e.g. number of successful operations, out of total operations).

\section{... and for the financial sector}

In financial services, output (Financial Intermediation Services Indirectly Measured, FISIM) is calculated as the difference between the effective rates of interest payable and receivable, and a "reference" rate of interest. In the banking sector, for instance, it is based on the observation that depositors are usually paid an interest rate that is below the risk-free reference rate. The difference represents the value of depositor services produced by banks, in the form of safekeeping, bookkeeping and payment services. On the other hand, borrowers almost always pay an interest flow above the risk-free reference rate. In this case, the difference represents the value of borrower services provided by banks in the form of credit-rating and monitoring.

Source: Sorbe et al. (2019), Mersch (2008), OECD (2013), ONS website. 
Productivity growth in the construction and in the transport sectors disappointed across the board both in the United Kingdom and in the average of OECD countries. The contributions to the productivity shortfall in those sectors in the United Kingdom appear to be close to the average contribution observed in OECD countries.

\section{Productivity in the service sector needs to accelerate markedly}

Looking forward, illustrative simulations underline that improving aggregate productivity performance will require a marked rebound in services sector productivity growth (Figure 12). Achieving such a rebound will be extremely challenging, particularly following the COVID-19 crisis.

\section{Figure 12. Illustrative scenarios on productivity developments in the United Kingdom}

Labour productivity growth in the medium term

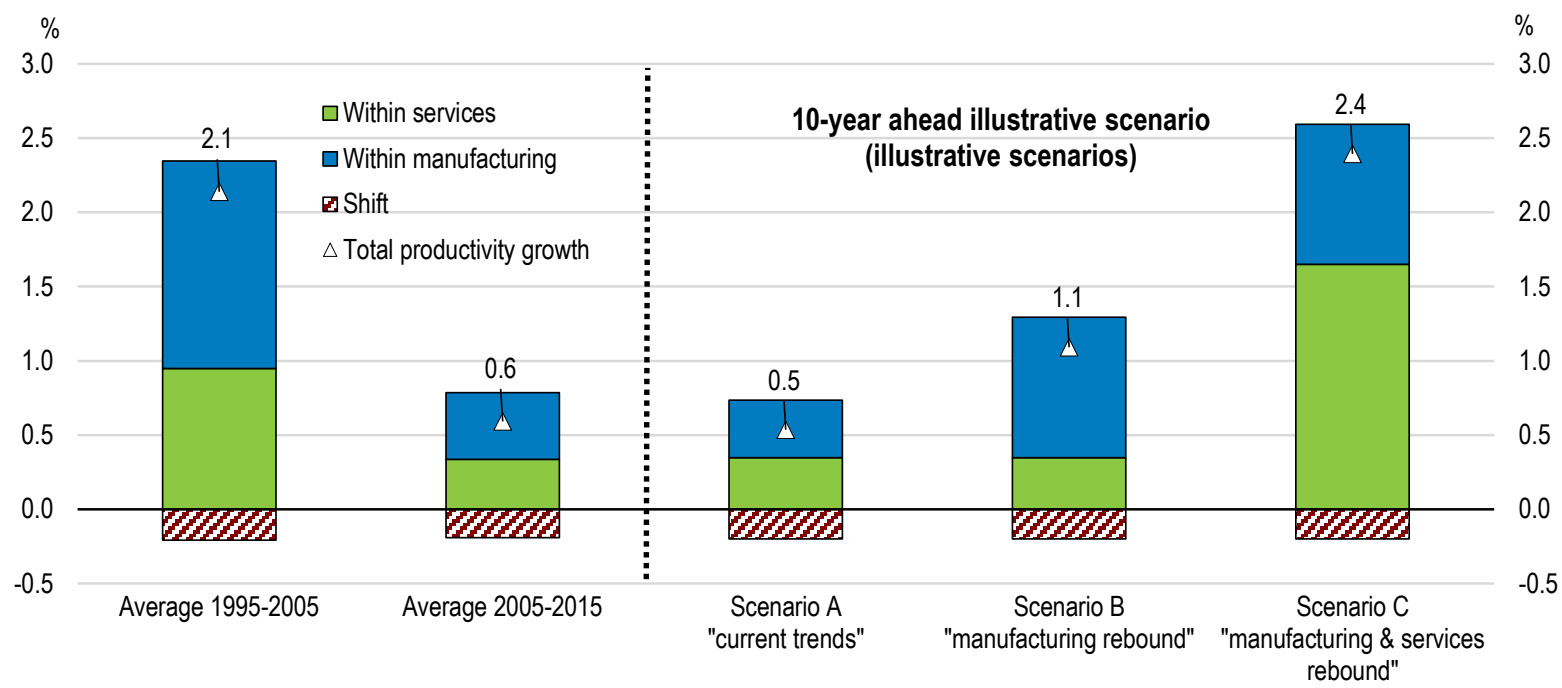

Note: The scenarios presented here solely aim at underscoring the key role play by the services sectors. They do present predictions nor seek to quantify the magnitude of the rebound that will be needed to recover from the COVID-19 crisis. Scenario A assumes that productivity growth over the medium term will be similar to what was observed during the 2005-15 period. Scenario B assumes that productivity will grow at rates similar to what was observed during the 2005-15 period in the service sector but will rebound in manufacturing to rates observed in 1995-2005. Scenario C assumes that productivity growth in the service sector will rebound to $2 \%$ and to the 1995-2005 average in manufacturing. Source: Calculations using Sorbe, Gal and Millot (2018).

StatLink त्ञाज https://stat.link/trblp3

If, once the COVID-19 crisis has passed, productivity growth were to return in all sectors to the rates observed after the financial crisis, economy-wide productivity would grow around $0.5 \%$ a year. A rebound in the manufacturing sector only, with its productivity growth returning to its 1995-2005 average, would only lead to a limited pick up in aggregate productivity. By contrast, productivity growth in the service sector needs to reach $2 \%$ - double the rate currently observed - in addition to the manufacturing rebound for aggregate productivity to grow at rates similar to what was observed over 1995-2005. This represents the direct contribution of the service sectors to productivity and does not account for the indirect input it can provide in raising the quality of products in other sectors (Sorbe, Gal and Millot, 2018). 


\section{Low investment and innovation rates and a lack of knowledge diffusion across firms are the main factors behind the poor productivity performance}

\section{A large part of the post-crisis productivity shortfall reflects low investment and slower innovation}

A simple way to examine the productivity growth slowdown is to use a standard growth accounting framework and split productivity growth into the efficiency with which both capital and labour are used to produce output - 'multi-factor productivity' and the amount of capital available per hour worked - 'capital deepening'.

Figure 13. Investment rates in the service sectors are low

Investment in the service sectors as \% of GDP

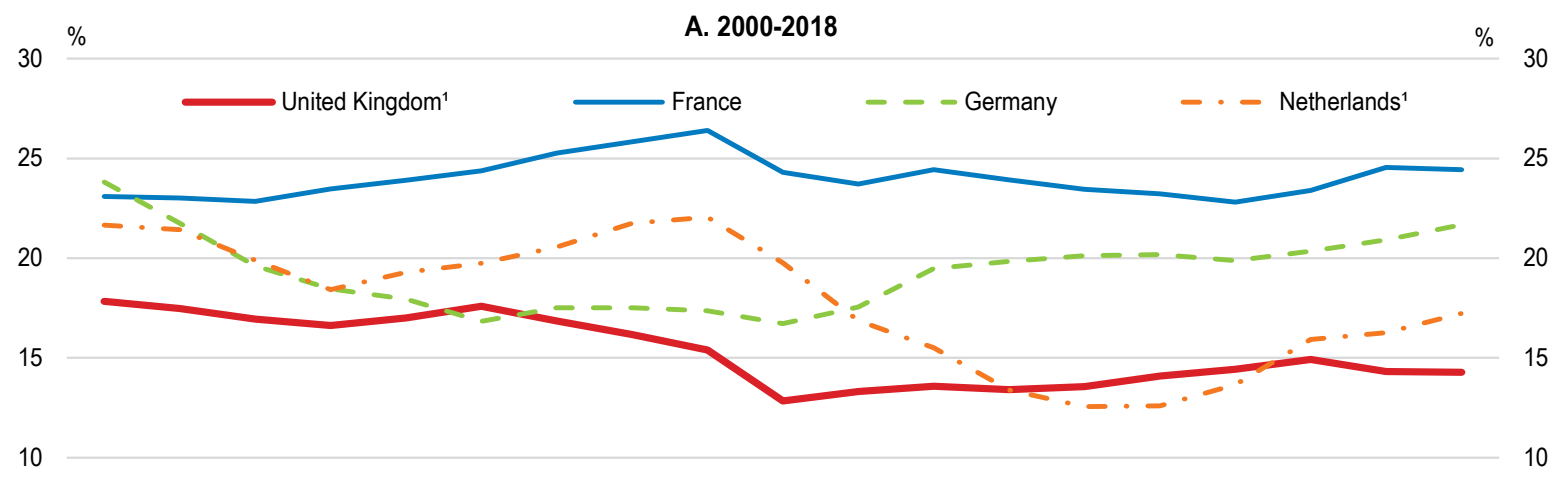

5 \begin{tabular}{lllllllllllllllllllllll}
5 & \\
\hline 2000 & 2001 & 2002 & 2003 & 2004 & 2005 & 2006 & 2007 & 2008 & 2009 & 2010 & 2011 & 2012 & 2013 & 2014 & 2015 & 2016 & 2017 & 2018 & 5
\end{tabular} $35 \%$

B. 2018 or latest year $\% 35$

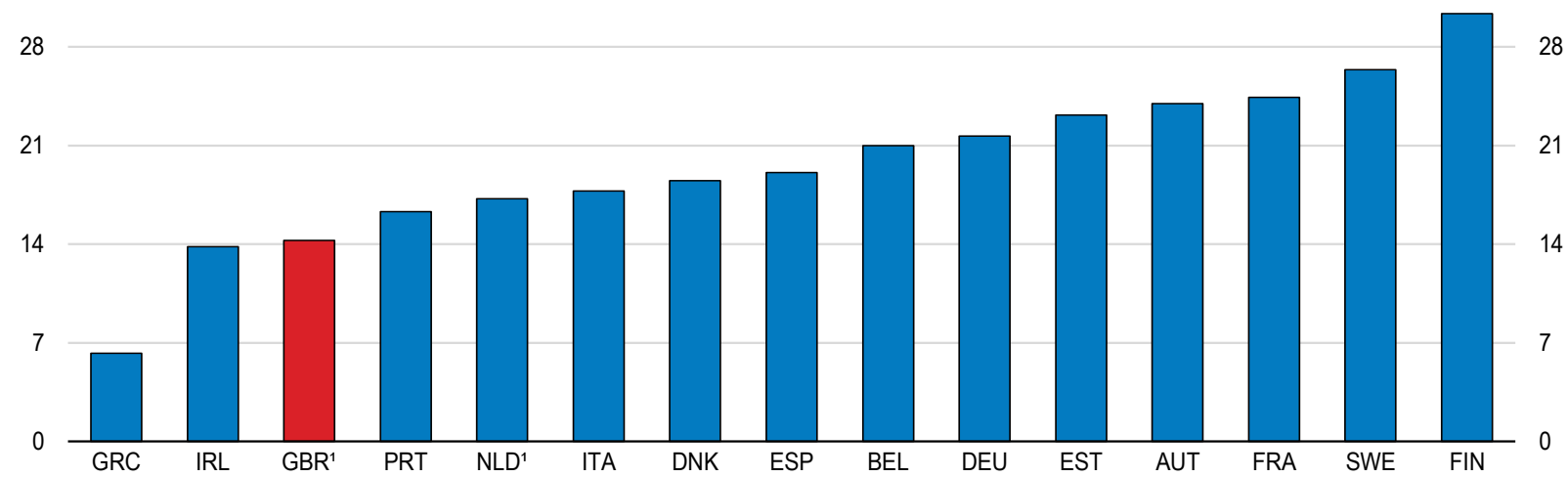

Note: Nominal gross fixed capital formation. Service sectors comprise information and communication (J), finance and insurance activities (K), real estate activities $(L)$ and professional, scientific and technical activities (M). Only some intangible assets (R\&D, software and databases, entertainment literary and artistic originals, and mineral exploration rights) are included in the national-account definition of investment. 1. For the United Kingdom, data on service sector output in 2017 and 2018 are computed using the output growth for the whole economy. For the Netherlands, investment data on professional, scientific and technical activities in 2017 is used for missing investment data in 2018. Source: Eurostat (2020), National accounts aggregates by industry (database) and Gross capital formation by industry (database). 
Multi-factor productivity (MFP) growth started weakening before the 2008 financial crisis in some sectors, such as the ICT sector. The UK Innovation Survey conducted by the ONS indicates a marked decline in the rate of both product and process innovation in UK firms. Still, the fall in the number of product innovators is estimated to account for less than one-tenth of the productivity shortfall relative to the pre-crisis trend between 2008 and 2012 (Barnett et al., 2014b).

Slower capital deepening can represent a significant part of the weakness in productivity growth even before the financial crisis. Investment in fixed capital in the service sectors has been low as a share of GDP in the United Kingdom (Figure 13). Both private and public investment have been sluggish (OECD, 2020a). Business investment collapsed after the financial crisis. It subsequently recovered but markedly slowed after the 2016 Referendum. There is increasing evidence that the sluggishness in investment reflects to a large extent Brexit-related uncertainties (Meloninna, Miller and Tatomir, 2018; Bloom et al., 2019).

Evidence also points to a strong correlation between intangible assets and productivity (Haskel and Westerlake, 2017). While investment in intangible assets is now, in terms of GDP, larger than investment in tangible assets in the United Kingdom, investment rates of intangible assets have also markedly declined in a few service sectors such as ICT, professional and scientific activities, administrative services and accommodation and food services (ONS, 2018a).

\section{A large tail of less productive firms accounts for much of the productivity shortfall in services}

Weak firm-level productivity, whether due to low multi-factor productivity or a low capital-to-labour ratio, seems a widespread phenomenon across sectors, firm size and firm age. Although small, young firms, in the hotel and restaurant and distribution sector, located in Wales and North East are over-represented in the bottom $10 \%$ of the productivity distribution, the worst-performing firms can be found in all regions, industries and size groups (ONS, 2017). These firms are likely to have weaker cashflows and are more likely to be impacted by the COVID-19 crisis relative to similar firms and the concentration in hotels, restaurants and distributions points to their exposure. Similarly, the most productive firms are found in a broad range of industries, in all firm sizes and regions.

The presence of zombie firms was found to have had only a small impact on aggregate productivity in the United Kingdom since 2008 (LSE Growth Commission, 2017; Adalet McGowan et al., 2017). Since the financial crisis, pressure for corporate restructuring may have been lower in the United Kingdom than in the previous recession and business liquidations have been low compared to the size of the output shock and relative to the previous recession of the early 1990s. This has been attributed to an extended period of low interest rates and the reluctance of banks to write off loans for poorly performing companies, granting them interest payment holidays instead (a phenomenon known as "forbearance"). This may raise difficult choices about how far firms with weaker performance can be supported following the COVID-19 crisis. Firm dynamism is generally relatively high in the United Kingdom (Figure 14). After a fall in the aftermath of the financial crisis, firm creation has started to recover and deaths fell as of 2012 (Anyadike-Danes and Hart, 2017). By 2014, births, deaths and the stock of continuing firms had recovered to pre-crisis values. Ensuring that conditions remain favourable to the creation of new and dynamic firms will be important in the coming years as the economy recovers. Strong business dynamism implies labour adjustment and reallocation to new positions, which require skills that are not necessarily similar to positions that have been destroyed. It will be also important to make sure that workers have the right skills to work in a new environment and that adequate training is available (see below).

One specificity of the UK economy is a larger share of low-productivity firms than in other advanced economics such as France or Germany (Figure 15). At the other end of the spectrum UK top-productivity firms perform relatively well by international standards (ONS, 2017). The productivity gap between the national top and bottom-performing $25 \%$ of companies in the service sectors appears to be larger in the 
United Kingdom than in some other advanced economies (Figure 16). This productivity gap has also widened since the financial crisis, in the UK service sectors, while it has been stable or even declined in some other economies. ONS data suggest that productivity increased from 2003 to 2015 for both the bottom $10 \%$ and the top $10 \%$ firms, but the latter experienced stronger growth.

One reason for the large gap is that knowledge diffusion from leaders to less innovative firms may have been weaker after the financial crisis (Andrews, Criscuolo and Gal., 2016; Haldane, 2018). According to Cornell University, INSEAD and WIPO (2019), the United Kingdom ranks only $12^{\text {th }}$ globally for knowledge diffusion and $27^{\text {th }}$ for knowledge absorption, although it ranks $5^{\text {th }}$ in the global index. This ranking is based on a variety of indicators including intellectual properties receipts, high-tech and ICT services exports, and FDI outflows. Accelerating knowledge diffusion and absorption would narrow the productivity gap between leader and laggard firms.

\section{Figure 14. Firm dynamism is relatively high}

Birth and death of firms, Information and communication technology (ICT) services, 2017 or latest year
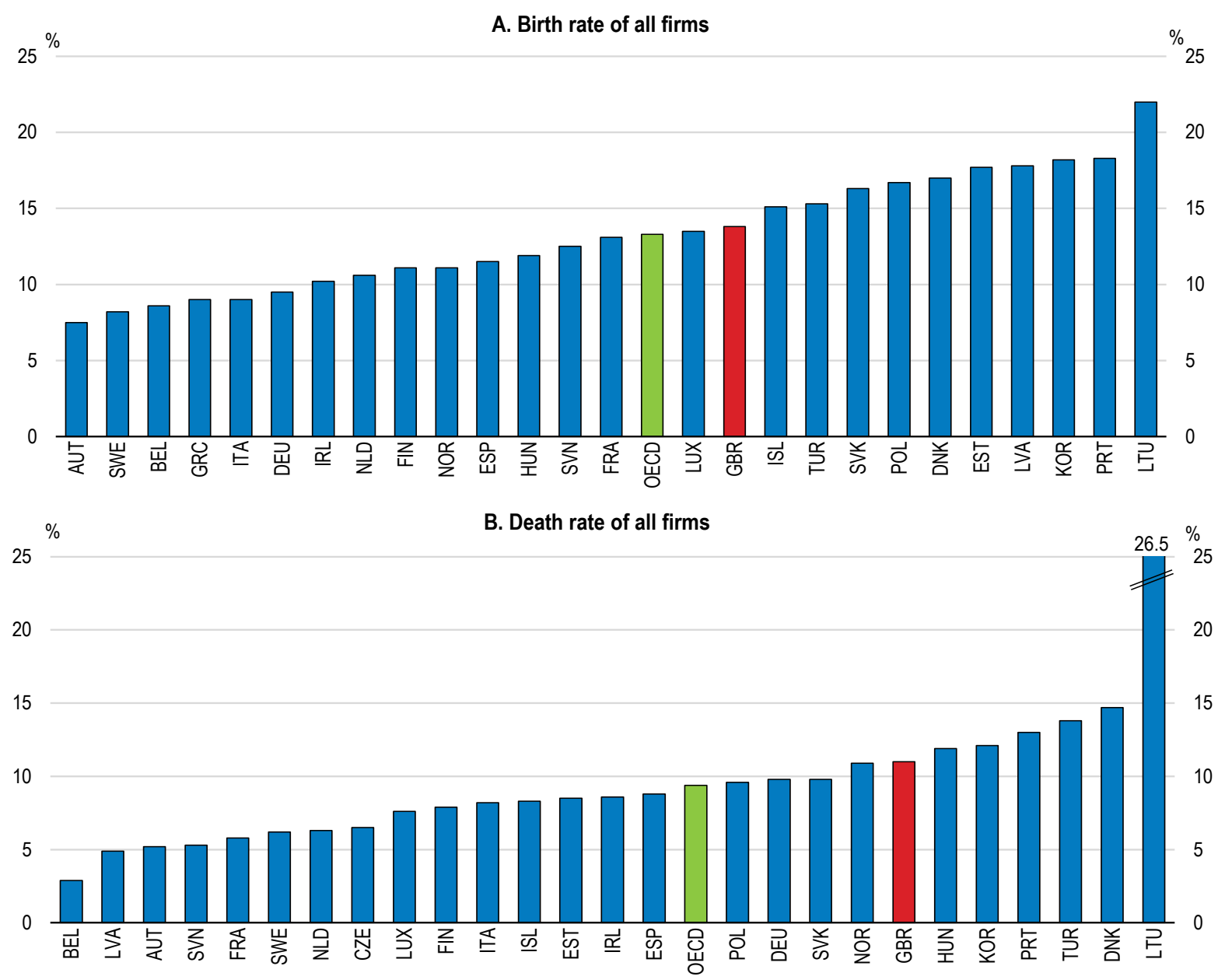

Note: Data refers to the private sector economy. ICT services are defined as the aggregate of the following activities (ISIC rev. 4): ICT trade industries, Software publishing, Telecommunications, Computer programming, consultancy and related activities, and Repair of computers and communication equipment. Unweighted average for the OECD aggregate.

Source: OECD (2020), OECD Structural and Demographic Business Statistics (database). 
Figure 15. The United Kingdom displays a long tail of low-productivity firms

Distributional estimates of multi-factor productivity (MFP), 2016

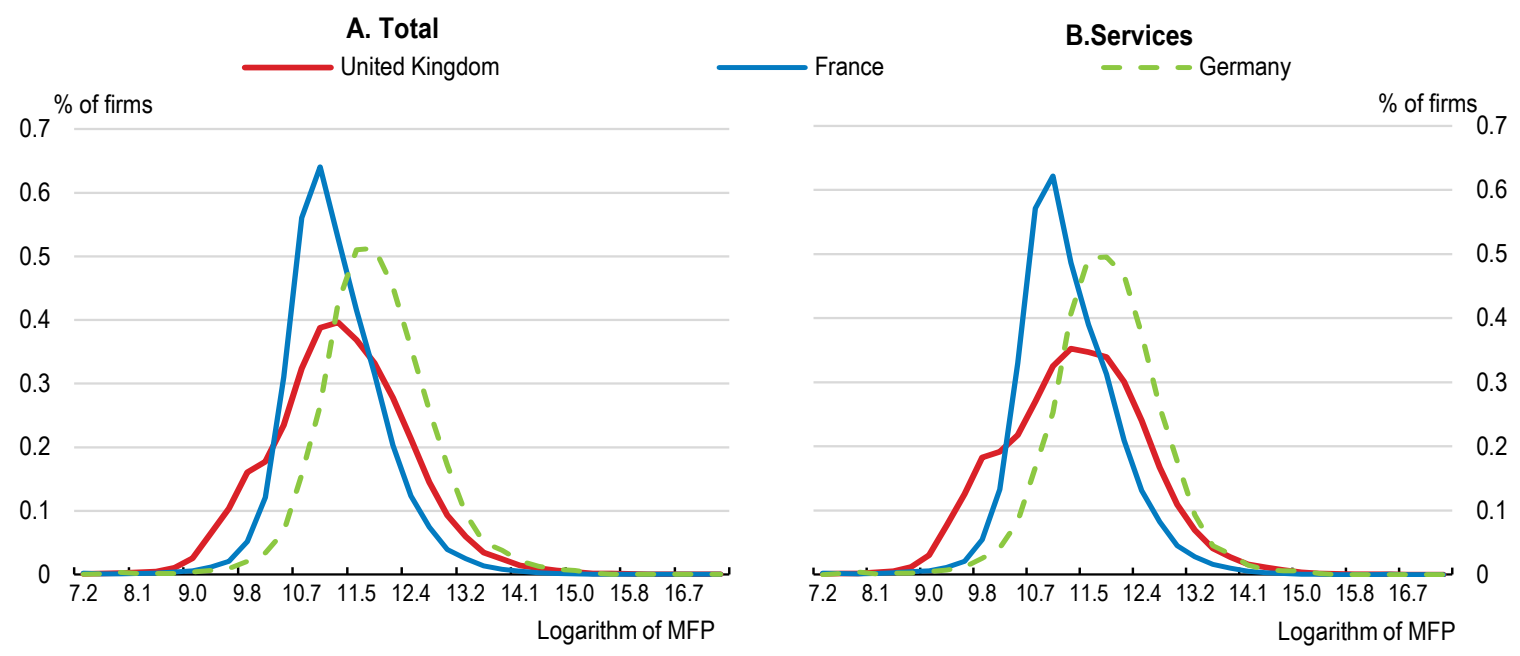

Note: Multi-factor productivity is computed using the Wooldridge method. The business service sector excludes the financial sector. The sample includes firms with at least 20 employees on average over their observed lifespan. Data for Germany may suffer from selection bias. Because of the cleaning of the dataset, well-performing firms are not represented in this chart.

Source: OECD calculations based on ORBIS data.

StatLink त्ञाs https://stat.link/umf01n

Figure 16. The productivity gap between leader and laggard firms is higher in the United Kingdom

Ratio of $10 \%$ of firms with highest multi-factor productivity to $25 \%$ of firms with lowest productivity

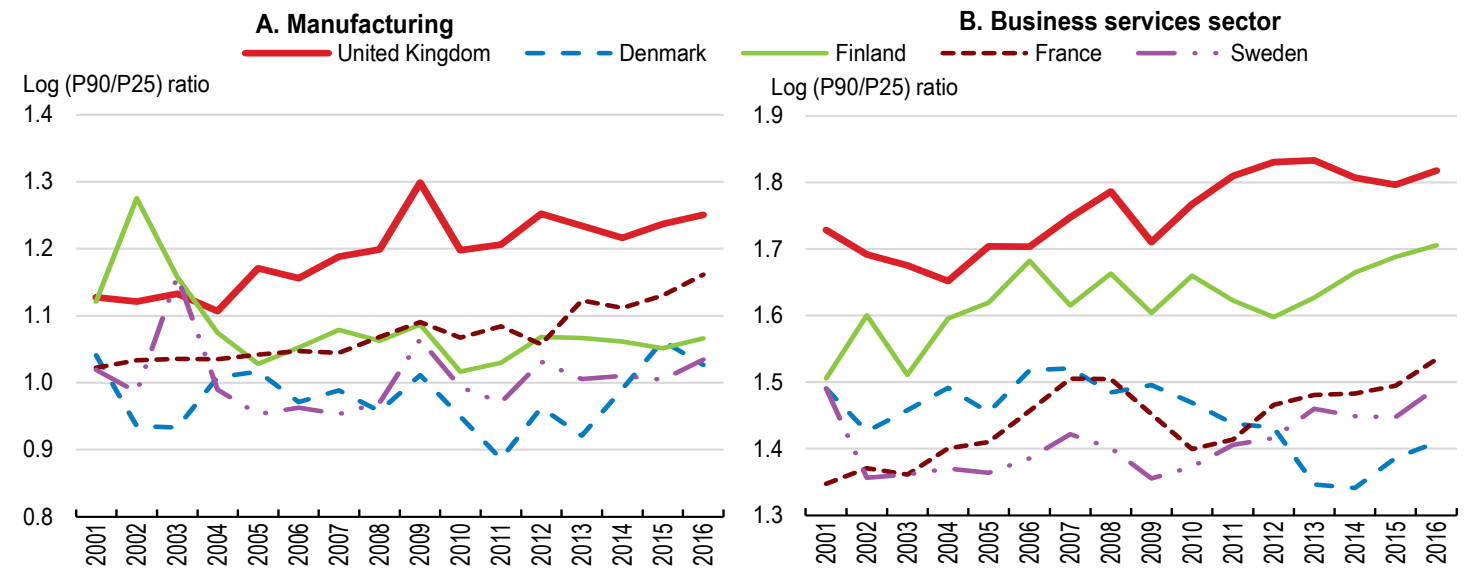

Note: Multi-factor productivity is computed using the Wooldridge method. The business service sector excludes the financial sector. The sample includes firms with at least 20 employees on average over their observed lifespan.

Source: OECD calculations based on ORBIS data.

StatLink הत्ञाs https://stat.link/Opakqt

\section{How to encourage firms to adopt new technologies}

Digitalisation is likely to have contributed to the divergence between leader and laggard firms since this trend is in most OECD countries more pronounced in digital-intensive industries (Gal et al., 2019). Moving to a digital economy will also be key to support the recovery in a context where firms and households will have to adapt their behaviour to distancing rules and other measures to limit the spread of the virus until a 
vaccine or a treatment are readily available. The following sections review policies which could help foster productivity, by improving investment, innovation or knowledge diffusion across firms.

\section{Some firms are not engaging in the most advanced technologies}

The United Kingdom fares relatively well in terms of adoption rates in basic technologies but less so in terms of more advanced technologies (Figure 17).

Figure 17. Adoption of new technology lags the best performers
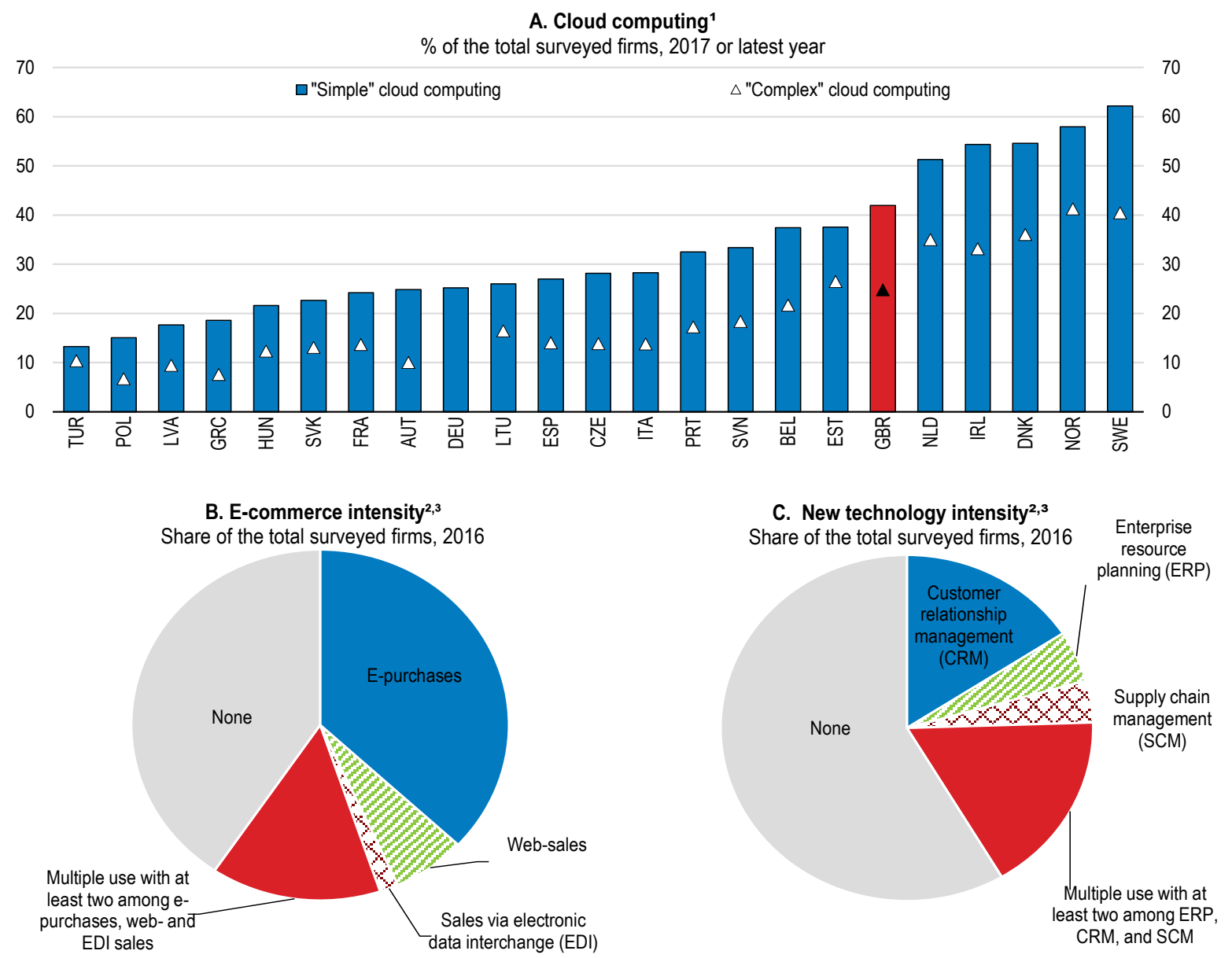

1. Adoption rate of "simple" (e.g. e-mail services) and "complex" (e.g. online renting of data or computing capacities) cloud computing services among firms with at least 10 employees. The figure presents the average adoption rate across industries in each country, using the industry structure of the United States as a benchmark to weigh industries in order to avoid that differences in industry structure affect the results.

2. Based on the E-commerce survey. Firms with at least 10 employees.

3. Firms' use of electronic platforms and software to manage their business processes.

Source: ONS (2019), "Information and communication technology intensity and productivity" and Sorbe et al. (2019), "Digital dividend: policies to harness the productivity potential of digital technologies", OECD Economic Policy Papers, No. 26.

StatLink הत्ञाs https://stat.link/naxhg2

Access to basic ICT technologies, such as the use of computers, having internet access, fixed broadband and a website have become mainstream. Still, there appears to be a tail of companies (representing around $10 \%$ of companies, predominantly small) which have adopted only some of these technologies. According to the ONS Annual Business Survey dataset, a notable share of firms has no ICT activity in relation to business organisation $(24 \%)$ and e-commerce (17\%). Adoption rates of advanced forms of new technologies are also lower than in leading countries. Low adoption rates of more advanced technologies 
are a potential factor explaining the poor productivity performance. OECD and ONS work suggest that firms engaging in new technologies get a significant productivity premium, especially when they combine a number of new technologies, but that the benefits are not evenly spread across firms (Box 3 ).

\section{Box 3. Does engaging in new technologies boost productivity?}

This box reviews evidence on the impact of new technology adoption on productivity, drawing on Sorbe et al. (2019) and ONS (2018b).

\section{Digital technologies support productivity...}

Focusing on European countries and some forms of digital technologies, OECD work suggests that productivity gains from digital adoption can be substantial. This can reflect both productivity increases by the firm adopting these new technologies (including the benefits of concomitant investments in human and organisational capital) and positive spillovers to other firms in the same industry, such as suppliers benefitting from more fluid interactions or competitors induced to increase their productivity.

Looking at UK data, ONS (2018b) finds a significant productivity premium for engaging in new technologies. The premium is around $10 \%$ for firms using e-purchases. The use of any combination of enterprise resource planning, customer relationship management and supply chain management technologies is associated with a productivity premium of around $25 \%$. Direct employment, outsourcing and providing ICT training to employees appear to be associated with a productivity premium, but businesses in the service industries only experience a premium when using a combination of these methods.

\section{... but not uniformly across firms}

Although evidence shows that, on average, the take up of technologies will enhance productivity, their impact may differ across types of firms (Bailin Rivares et al., 2019). Productivity gains from digital adoption depend crucially on firms' organisational capital and management skills, as well as on their ability to deploy complementary investments and innovations to improve business processes and automate certain routine tasks. In addition, productivity gains can take time to materialise.

The productivity benefits from digital adoption appear less in services than in manufacturing, and more generally tend to be higher in industries that are intensive in routine tasks. This confirms that streamlining or automating routine tasks is one of the channels through which digital adoption increases productivity. In the case of the retail sector, for example, the consequences of online retailing for labour productivity may vary between different segments of the retail sector. Selling retail services online can have low marginal costs and offer major benefits from potentially unlimited capacity. Some online retailers can achieve much higher labour productivity from consumer self-service, where product research and self-administered purchasing transactions can replace human services (Pike, 2015). Elsewhere, online businesses invest in a virtual 'chat' service for more complicated products. New online firms often emerge outside the traditional retail footprint in areas such as financial services and travel firms, and the retail sector more widely could learn from them. In contrast, supermarkets, which account for around $40 \%$ of consumer retail spending in the United Kingdom, may experience static or reduced labour productivity. This is because providing an online sales channel for low-value items such as groceries is very labour intensive for retailers.

Source: Sorbe et al. (2019) and ONS (2018b). 


\section{4 | ECO/WKP(2020)37}

As in other economies, the use of technology to support teleworking has been a key element of maintaining activity during the COVID-19 crisis. The effect of this change in working arrangements on productivity are still uncertain. To maximise the productivity gains from the use of more widespread teleworking, governments should promote investments in the physical and managerial capacity of firms and workers to telework and address potential concerns for worker well-being and longer-term innovation related in particular to the excessive downscaling of workspace (OECD, 2020c).

The most productive firms are usually characterised by good management and digital skills and more prone to reorganise production processes, explaining why they are more likely to adopt new technologies and to benefit more from adoption (Gal et al., 2019). The contrast between upper-tail companies which are fast adopters of new technologies and slow technology-adopter firms is even more marked than for basic technologies (Haldane, 2018). A lack of awareness or trust, as well as the difficulty to quantify the benefits of those technologies could explain those low take-ups.

\section{Figure 18. A range of policies can support productivity through digital adoption in the United} Kingdom

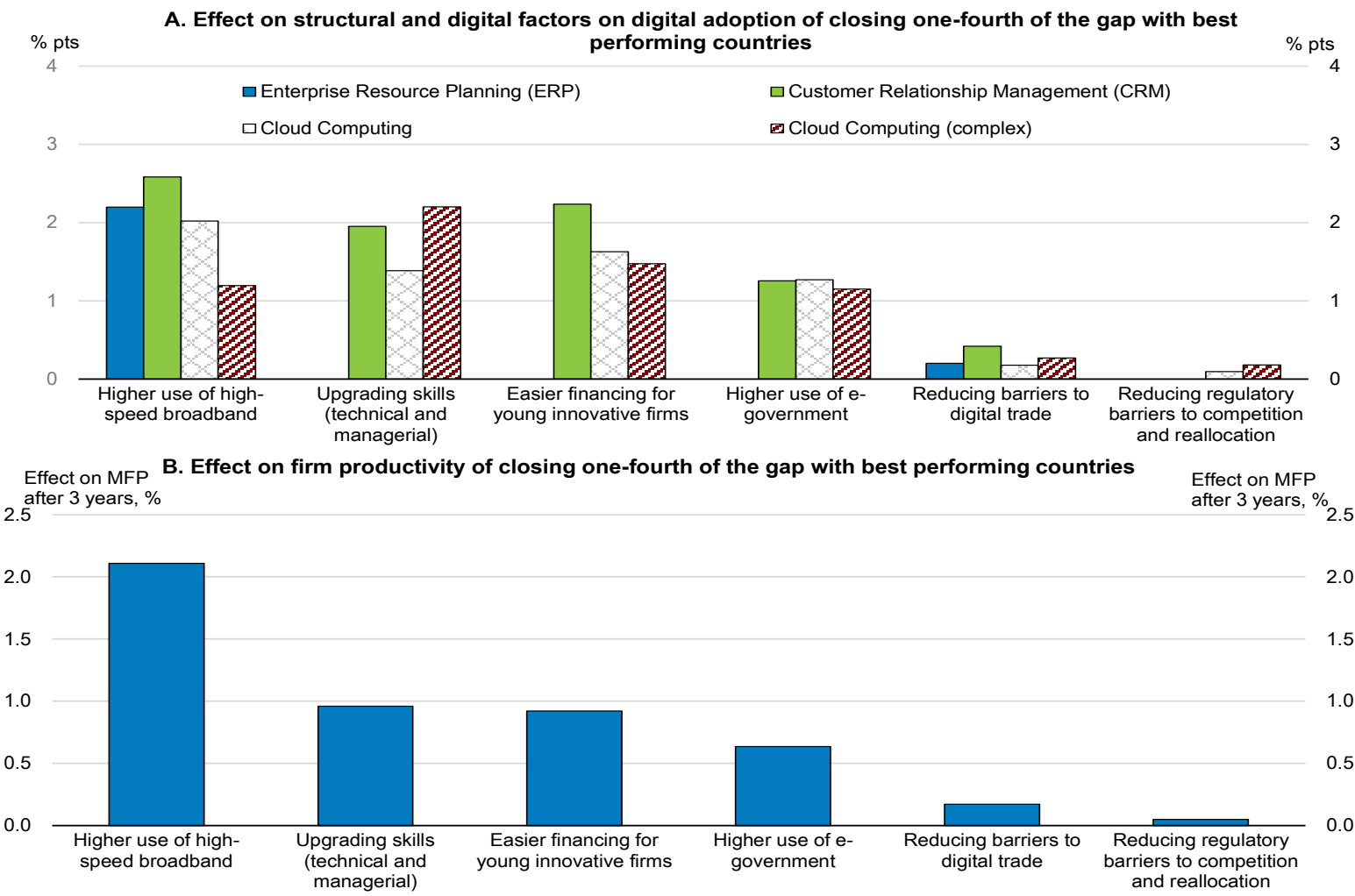

Notes: Estimated effect on the multi-factor productivity (MFP) of the average firm of a range of policy and structural factors which are found to support the adoption of new technologies: The effect of "Higher use of high-speed broadband" on productivity combines the direct and indirect effects presented in Figure 6 in Sorbe et al. (2019). "Upgrading skills" covers participation in training, quality of management schools and adoption of High Performance Work Practices. "Reducing regulatory barriers to competition and reallocation" includes lowering administrative barriers to start-ups, relaxing labour protection on regular contracts and enhancing insolvency regimes. "Easier financing for young innovative firms" covers the development of venture capital markets and the generosity of R\&D tax subsidies. It is assumed that policy factors in each group are largely independent from each other.

Source: Sorbe et al. (2019), "Digital dividend: policies to harness the productivity potential of digital technologies", OECD Economic Policy Papers, No. 26. 
Illustrative scenarios from Sorbe et al. (2019) suggest that policy reforms to facilitate the take-up of digital technologies could bring significant productivity dividends. Such estimates should be treated with caution, as they do not, for instance, assess causality. Although the magnitude of the estimated impact is uncertain, those simulations are useful to identify priorities. For instance, filling some of the gap in adoption rates of enterprise resource planning, customer relationship management and cloud computing compared to the best-performing countries could bring large productivity dividends in the medium term in the United Kingdom (Figure 18). This could be done by developing high-speed broadband infrastructure, upgrading skills, easing financing conditions of young and innovative firms and making higher use of e-government. The United Kingdom would benefit from keeping low digital-trade barriers to trade and investment.

\section{Facilitating access to digital infrastructure}

Improving the use of digital infrastructure is expected to bring large productivity dividends in the United Kingdom. Although it has improved, the share of firms accessing high-speed broadband remains below that of many other European countries (Figure 19).

\section{Figure 19. The share of firms with high-speed broadband is lower than in peer countries}

Broadband connections, by speed, \% of the total surveyed firms, 2019 or latest year

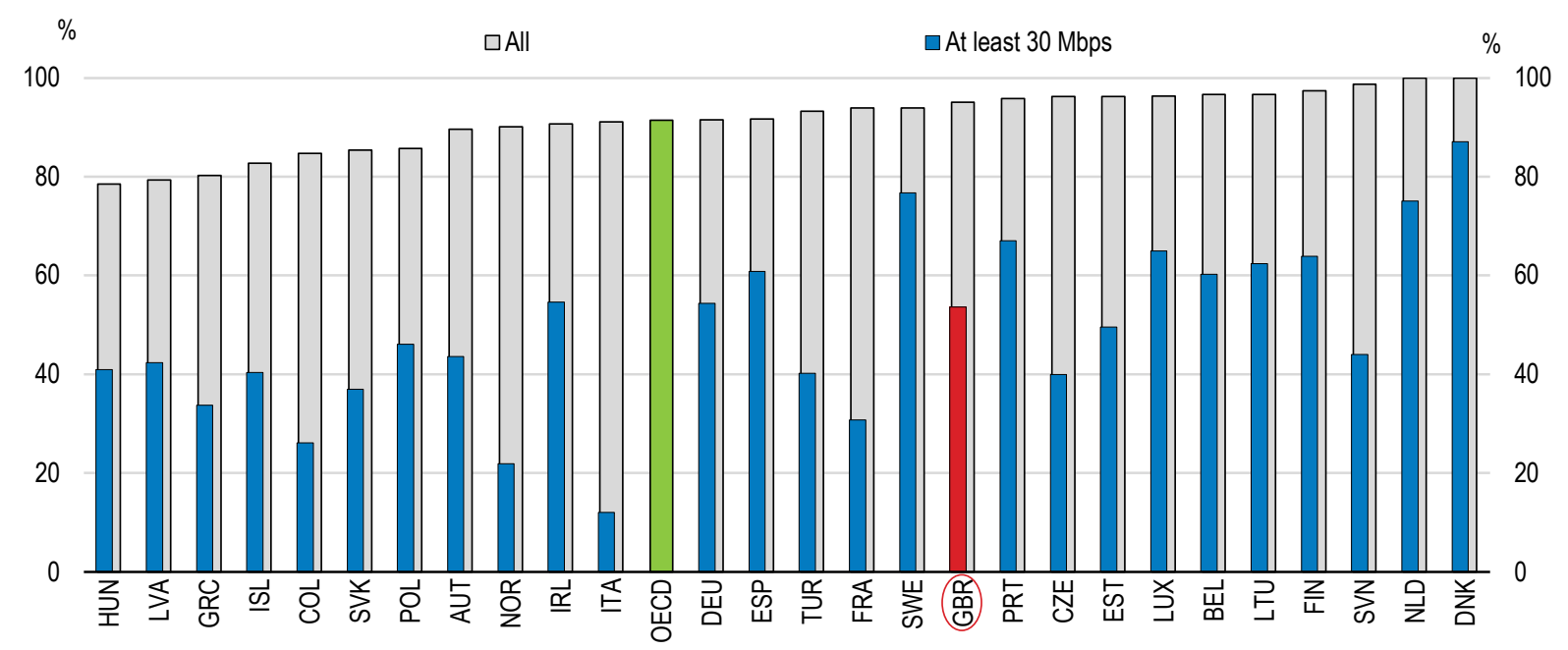

Note: High-speed broadband refers to at least $30 \mathrm{Mbit} / \mathrm{sec}$ data transfer speed. Only firms with at least 10 employees. Average across industries in each country, using the industry structure of the United States as a benchmark to weigh industries in order to avoid that differences in industry structure affect the results.

Source: OECD (2020), ICT Access and Usage by Businesses (database).

StatLink הत्ञाs https://stat.link/5npadc

In addition to fostering productivity, increasing investment in digital infrastructure will also help to bridge the digital divide. Access to high-speed broadband is particularly difficult in rural areas whose coverage lags behind that of urban areas, like in many other OECD countries. Although the access gap has declined since 2010 , the low quality of broadband connections in rural areas, in terms of connection speed, time taken to transfer data between users or devices and errors in data transfer needs to be addressed. Mobile broadband prices are estimated to be below the OECD average, according to the OECD telecommunication price baskets measures.

Building world-class digital infrastructure is one of the stated priorities of the UK Digital Strategy, published in 2017, and the Digital Economy Act 2017 addresses key issues relating to electronic communications 
services. The Government's ambition is to have nationwide gigabit-capable broadband as soon as possible, with an ambition to deliver by 2025. The United Kingdom has also committed to extend geographic coverage to $95 \%$ by 2025 . Through the Future Telecoms Infrastructure Review, it has set out a regulatory model to promote network competition and private sector investment in digital infrastructure. The publication of the National Infrastructure Strategy was delayed, but the Government committed in the March 2020 Budget to GBP 5 billion (0.2\% of GDP) investment in gigabit broadband rollout in the hardestto-reach areas by 2025 and to fund the GBP 1 billion shared rural network for mobile coverage by GBP 500 million, with the remaining matched by industry. Despite these efforts, planned investment for 202021 in digital infrastructure is small compared to investment in transport and utilities (Figure 20).

The Government set out plans for the public sector to investment GBP 640 billion over the next five years (on average $5.8 \%$ of GDP per year). This can help address the challenges brought by the management of the COVID-19 crisis and facilitate the adjustment of firms to the new business environment. It will be important to communicate rapidly on the timing and the allocations of those investments to shape firms' expectations and encourage private investment. Investment in digital infrastructure should be prioritised. Such investment has been found to bring large productivity gains and to be a prerequisite to the adoption of digital technologies (OECD, 2019c). The Government may invest directly in high-speed fixed networks or incentivise private investment, including by competitive tendering, tax exemptions, low-interest loans or lower spectrum fees (OECD, 2018a).

Figure 20. Most major investment projects are in transport, energy and utilities

Decomposition of investment, by sector

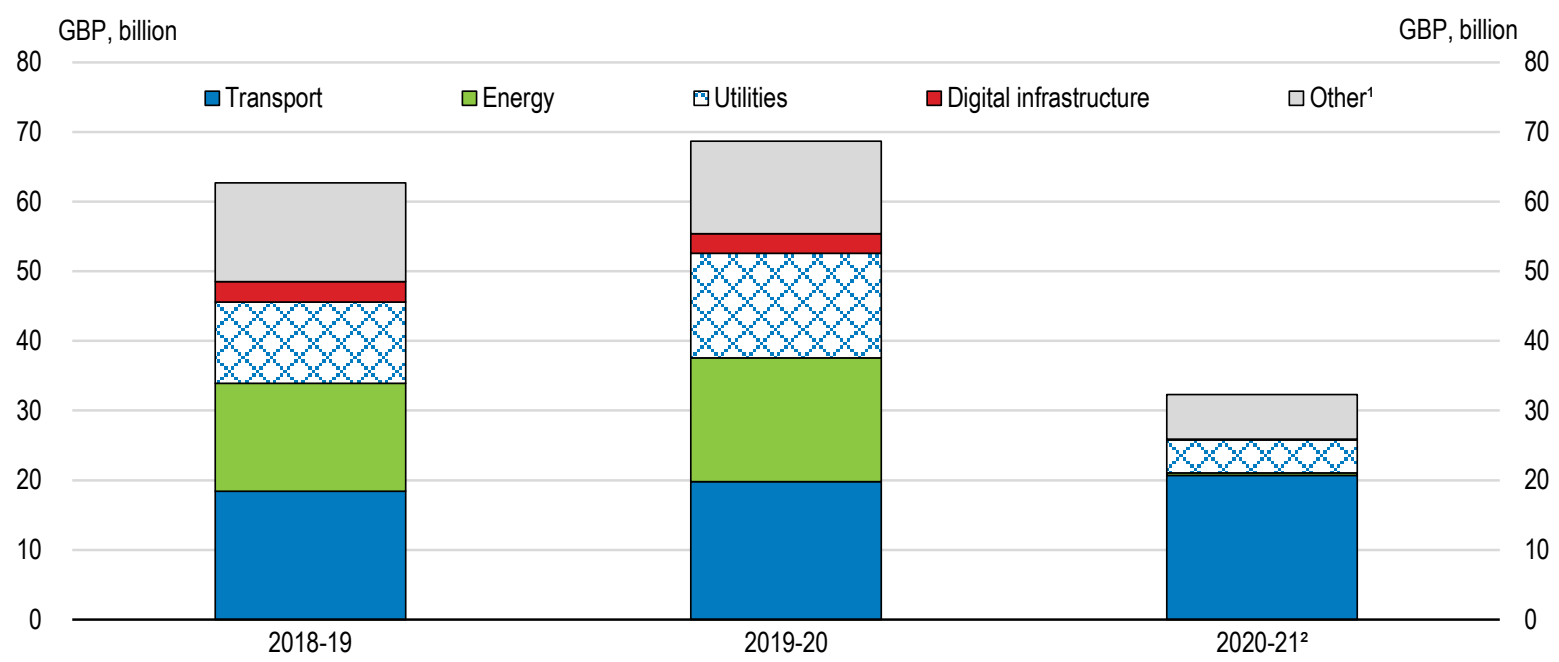

1. Includes other programmes such as science and research, flood and coastal erosion, and social infrastructure.

2. Based on "National infrastructure and construction procurement pipeline 2020/21, June 2020. Estimated maximum contract value.

Source: Infrastructure and Projects Authority, "Analysis of the national infrastructure and construction pipeline", Policy paper, November 2018 and "National infrastructure and construction procurement pipeline 2020/21", June 2020.

StatLink : הils https://stat.link/7ih6dq

\section{Improving Research and Development support}

Spending on Research and Development (R\&D) is a key driver of innovation and hence productivity growth. It has increased in the United Kingdom as a share of GDP over the past decade. However, at $1.7 \%$ of GDP in 2018, R\&D spending is still low compared to peer countries (Figure 21). The United Kingdom 
has invested less in R\&D than France as a share of GDP since 1986 and less than Germany since 1980. In addition, three-quarters of its private R\&D spending is concentrated in only 400 companies. Among smaller firms, the United Kingdom ranks low compared to European countries in terms of in-house innovation and the introduction of new products and processes (Haldane, 2017).

The Government has committed in its Industrial Strategy to increase overall UK investment in R\&D from $1.7 \%$ to $2.4 \%$ of GDP by 2027 . This is welcome. This would bring the United Kingdom close to the current OECD average, but Germany is aiming to invest 3.5\% of GDP in R\&D by 2025 . A few countries such as Austria, Sweden or Finland already invest around 3\% of GDP in R\&D, with Israel and Korea investing larger amounts of around $4.5 \%$ of GDP.

\section{Figure 21. Spending on research and development is lower than the OECD average}

Research and development expenditure, 2018 or latest year

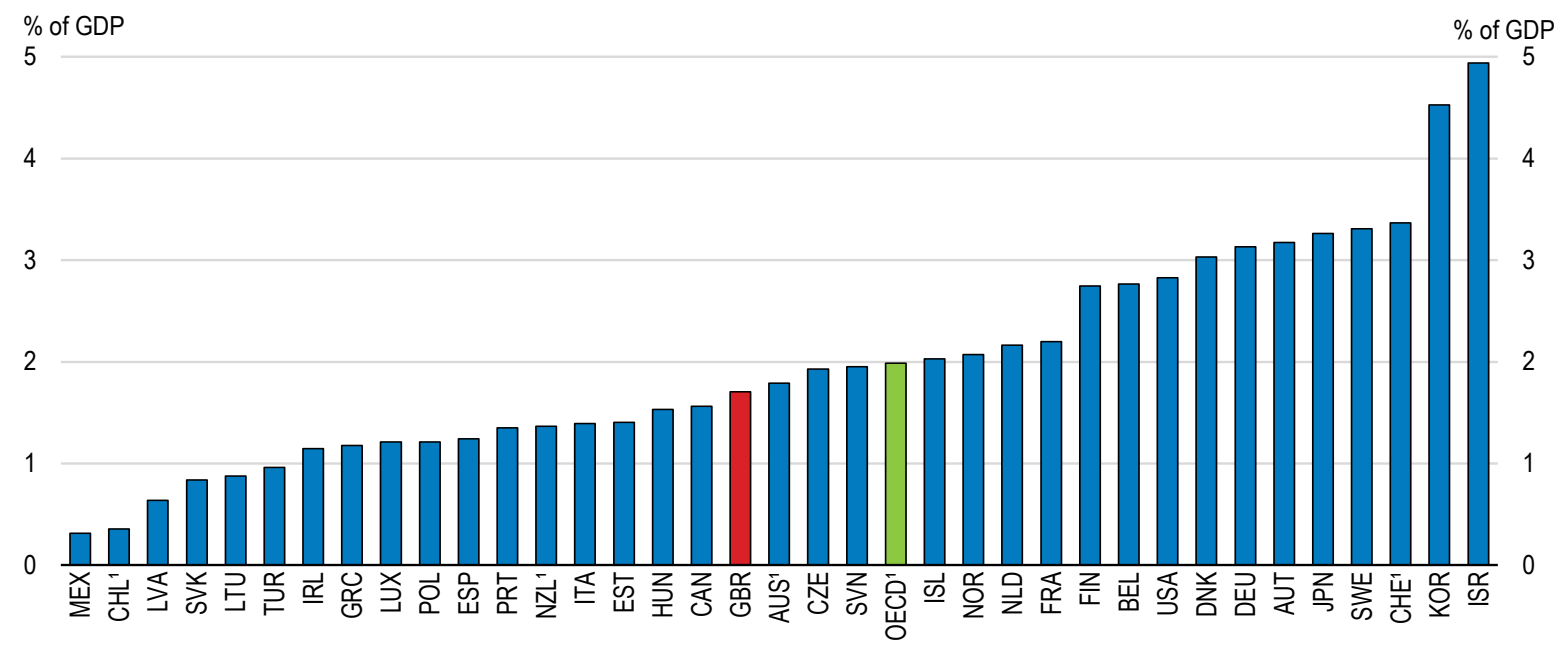

1. Unweighted average for the OECD aggregate. 2017 for Australia, Chile, New Zealand and Switzerland.

Source: OECD (2020), Main Science and Technology Indicators (MSTI database).

StatLink ज्ञाs https://stat.link/yhmpuj

Support to spur R\&D spending in the United Kingdom has increased over the years, faster than in the median of OECD countries. Total support amounted to $0.3 \%$ of GDP in 2017 , up from $0.12 \%$ in 2006 , placing it in the top providers of support amongst OECD countries (OECD, 2019d). Tax credits still account for $60 \%$ of government support but there is evidence that the cost of these measures has been increasing over time (HM Revenue and Customs, 2018). In March 2020, the Government announced an increase in the tax credit and broadened the scope of qualifying expenditure to include data and cloud computing. It also set out plans to increase public R\&D investment to GBP 22 billion (1\% of GDP) per year by 2024-25, taking direct support for R\&D to $0.8 \%$ of GDP and placing the United Kingdom among the top quarter of OECD countries. Direct support is predominantly accessed by large firms, which may explain in part why R\&D spending is concentrated in a few large firms (Figure 22). This differs from a number of other OECD countries, where direct support is often disproportionally channelled towards small and mediumsized enterprises and firms which are not part of larger business groups (OECD, 2019d).

Both types of support present advantages and drawbacks and the optimal balance of R\&D support varies from country to country and can evolve over time (Appelt et al., 2016). Overall, there appears to be broad consensus that tax incentives are more suited in principle to encourage R\&D activities oriented towards the development of applications that have the potential to be brought to the market within a reasonable 
timeframe. In contrast, grants are more suitable for supporting longer-term, high-risk research and for targeting specific areas that generate public goods or that have particularly high potential for spillovers.

It will be important to continue to boost direct funding and ensure balanced support between the two sources of funding to spur productivity and digitalisation as the economy recovers from the COVID-19 crisis. This spending should be prioritised to leverage private sector innovation in potentially "disruptive" technologies. It will also be important to ensure that small innovative firms also benefit from this support. A number of countries, such as Australia, Estonia, Ireland and Luxembourg have introduced direct SMEtargeted funding and could provide good examples to consider (OECD, 2019b).

\section{Figure 22. Small firms only receive a limited share of support}

\% of government support for business R\&D, 2017 or latest year

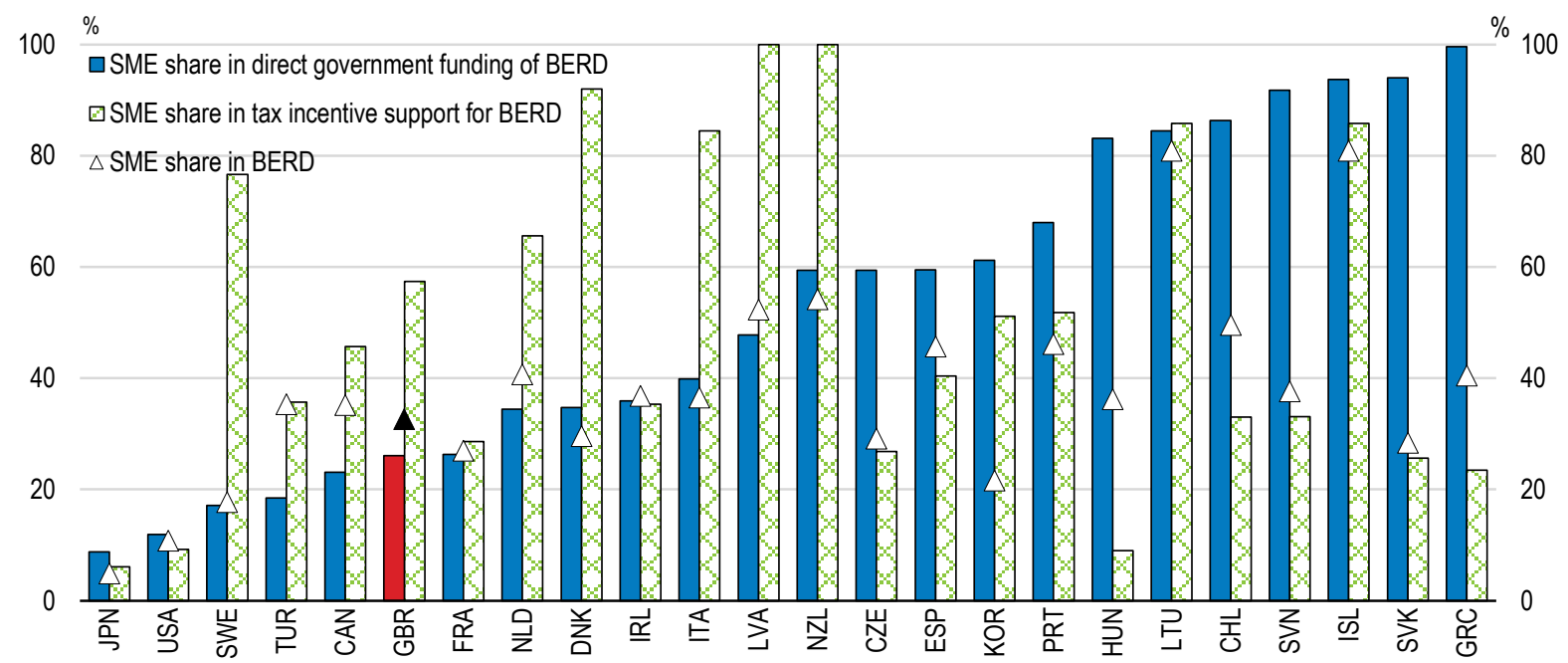

Note: International comparability may be limited, e.g. due to variations in SME definitions for business R\&D vs. R\&D tax relief reporting purposes. For more information on R\&D tax incentives, see http://oe.cd/rdtax. SMEs figures generally refer to enterprises with 1-249 employees.

Source: OECD (2020), OECD R\&D Tax Incentive Indicators, http://oe.cd/rdtax and OECD (2020), Research and Development Statistics (database).

StatLink त्गाs https://stat.link/5evgjy

\section{Easing access to finance of new and young firms}

Firms in the service sectors have suffered from financial pressures as lockdown measures have prevented sales while they continued to bear operating costs. Improving access to finance for new and young innovative firms would bring sizeable productivity gains. New firms represent a fair share of the total number of firms, with the service sector representing $98 \%$ of the newly created enterprises. Beyond the immediate needs, there is evidence of a gap in the supply and use of long-term/patient capital that is holding back firms from growing to scale (HMT, 2017; HMT 2018; IPO and British Business Bank, 2018). Against this background, a 10-year action plan was introduced in 2017 to unlock a total of over GBP 20 billion (1\% of GDP) to finance growth in innovative firms (HMT, 2017; HMT, 2018). Progress in implementation has been made since then and should continue.

\section{Better targeted support to small firms}

Small firms have experienced acute financial stress as a result of COVID-19, especially those operating in the service sectors which faced the most stringent restrictions. Emergency measures have been put in place to alleviate liquidity constraints, including grants to small business ( $0.7 \%$ of GDP) and business rate holidays $(0.5 \%$ of GDP). Those were necessary to prevent massive business failures and support income. 
Moving from an emergency to a recovery phase, it will be essential to restrict support to firms that face a liquidity issue but are viable in the medium term. This will favour the adjustment of businesses to the new environment.

Emergency measures add to the plethora of established government schemes to support the financing of small firms which have been introduced over the years. According to the 2019 OECD Scoreboard on financing SMEs and Entrepreneurs these include: government loan guarantees, direct lending to SMEs, special loans for start-ups, government export guarantee or trade credit, support to venture capital equity funding and business angels SME banks, business advice consultancy, tax exemptions and central bank funding to banks depending on lending rates. There are over 500 publicly funded schemes to support businesses (Page, 2018).

The rationale for specific schemes for long-term growth is sometimes unclear and some of these measures may not succeed in facilitating access to finance of small firms. To maximise the efficiency of support, it would be preferable to review the whole system of support and re-prioritise resources toward measures that respond to a genuine market failure and support production processes that are consistent with the protection of the environment. The focus should be directed to supporting young firms, especially those that are likely to be more innovative and/or operate with a sizeable share of intangible capital. Funding should also be redirected in priority to schemes which have been assessed to be efficient.

\section{Figure 23. Reliance on venture capital is relatively low}

Venture capital investments, 2018 or latest year

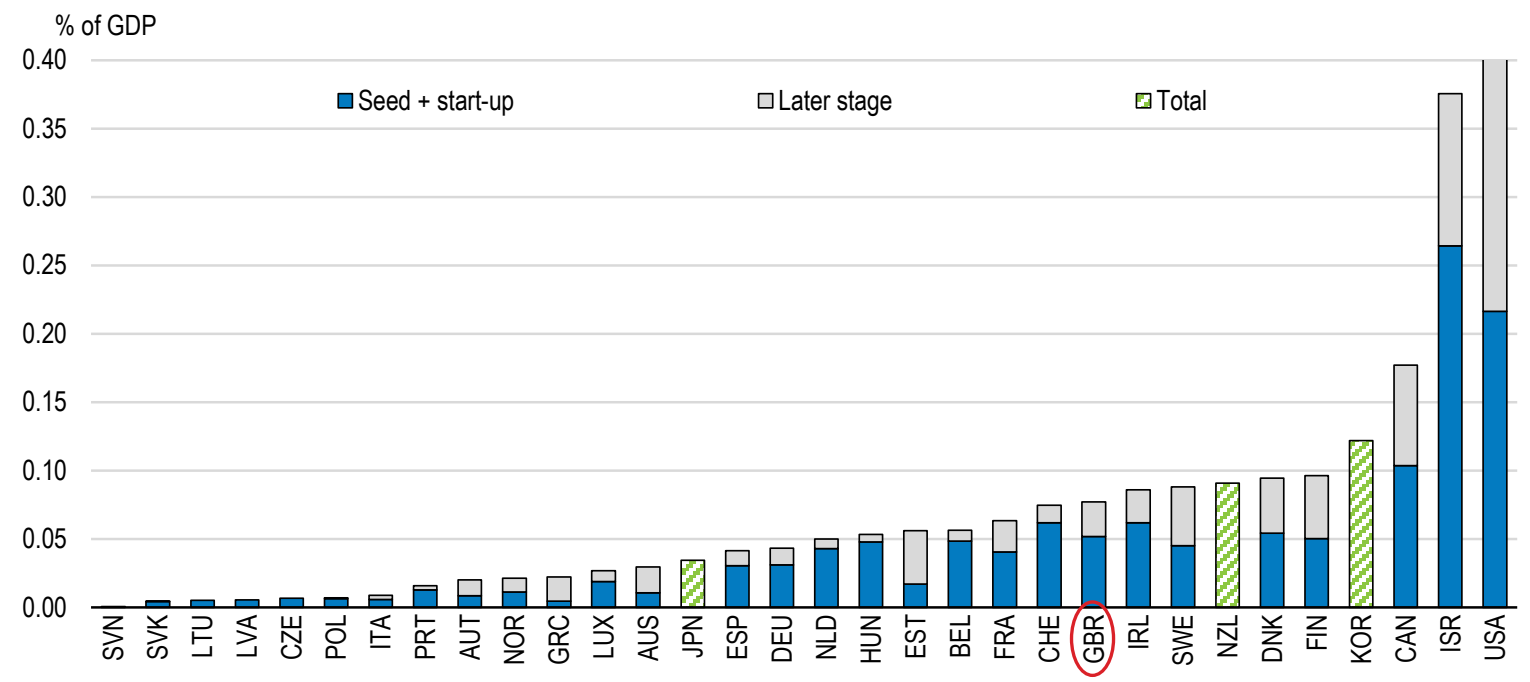

Note: Venture capital is a subset of private equity such as equity capital provided to enterprises not quoted on a stock market, and refers to equity investments made to support the pre-launch, launch and early stage development phases of a business. 2017 for Canada and Japan, and 2014 for Israel.

Source: OECD (2020), OECD Enterprise Statistics (database).

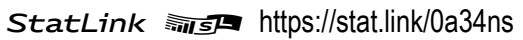

There is uncertainty around some of the public funding of venture capital in the long term. The European Investment Fund has been a major investor in venture capital. The Government has provided the British Business Bank (BBB) to make up to GBP 200 million of additional investment in UK venture capital and growth finance in 2019-20. This will complement support through the BBB's dedicated equity finance business, British Patient Capital, and the establishment of regional funds such as the Northern Powerhouse and Midlands Engine Investment Funds. Market imperfections in this segment and the small 
size of the venture capital market compared to Canada, Israel or the United States could justify government's intervention to develop the market (Figure 23). While the BBB's capacity has been increased this year, it will be important to secure funding on venture capital over a longer term and provide clarity to investors.

\section{Redirecting investment from long-term investors to innovative firms}

The United Kingdom has one of the biggest pensions markets (in terms of total assets) in OECD countries (Figure 24). According to the British Venture Capital Association, UK pension funds contributed $3.7 \%$ to the GBP 33.5 billion invested in venture capital and private equity in the United Kingdom in 2017, compared to $37.5 \%$ from overseas pension schemes. Removing barriers for UK funds to diversify their portfolios in these activities would increase the financing pool available to young innovative firms and help to support investment returns at a time when yields on other assets remain very low.

Since 2018, the Government has taken measures to remove barriers and support occupational definedcontribution (DC) schemes in investing in innovative companies, as part of a balanced portfolio. The approach is welcome to the extent it remains consistent with the original objective and mandate of the pension funds. A prerequisite is to consolidate DC schemes so that they have the critical mass to invest in higher-risk innovative activities.

\section{Figure 24. The pensions market is large}

Pension assets, 2018

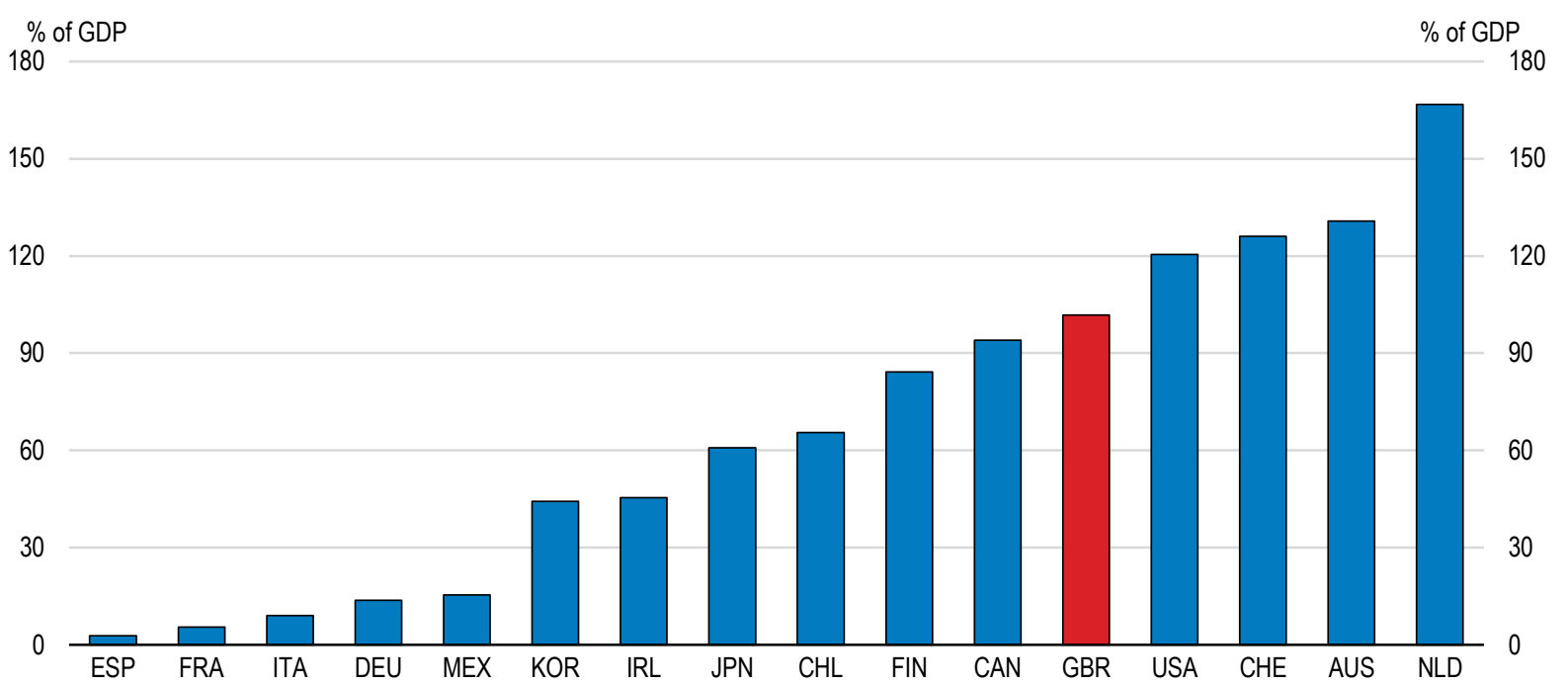

Note: Data for Germany includes pension assets for company pension schemes. For Japan, data does not include the unfunded benefit obligation of corporate pension plans. For Switzerland, data includes autonomous pension funds only and it does not consider insurance companies assets. Data for the United State includes IRAs.

Source: Willis Towers Watson (2019), Global Pension Assets Study 2019, Thinking Ahead Institute research.

StatLink :

\section{Encouraging equity-based financing}

Although equity markets are more developed than in many OECD countries, equity financing accounts for a very small share of total financing of small firms in the United Kingdom and is used by only $16 \%$ of small and medium-sized firms (Figure 25). In 2017, the debt-to-equity ratio of non-financial corporations in the United Kingdom was close to the OECD average. As in other countries, one factor explaining this outcome 
is the tax bias favouring debt rather than equity financing. The effective average tax rate on new equity is estimated to be 7 percentage points higher than on debt in the United Kingdom, a differential close to what was observed in the EU28 (ZEW, 2016). In addition to lowering public revenues, such a bias is often associated with financial instability (Landgedijk et al., 2015) and it would be useful to remove it.

A few countries have put in place various supports to ease access to equity, notably allowances for corporate equity (ACE). Such a scheme has already been applied in Belgium, Latvia and Portugal and is under consideration in Denmark (OECD, 2019e). The idea of the ACE is to maintain deduction of interest expenses and give a tax allowance for equity to achieve tax neutrality across debt and equity. The challenge to implement such a reform is the need to ensure that the ACE only applies to new equity to avoid windfall gains for the investment undertaken before the introduction and to determine an imputed rate of return (the so-called notional interest rate). The ACE can also lead to strategic tax planning by multinationals if not designed adequately and accompanied by specific anti-avoidance measures (Hebous and Ruf, 2017).

Figure 25. Equity capital is a small portion of SME finance in the United Kingdom

2018

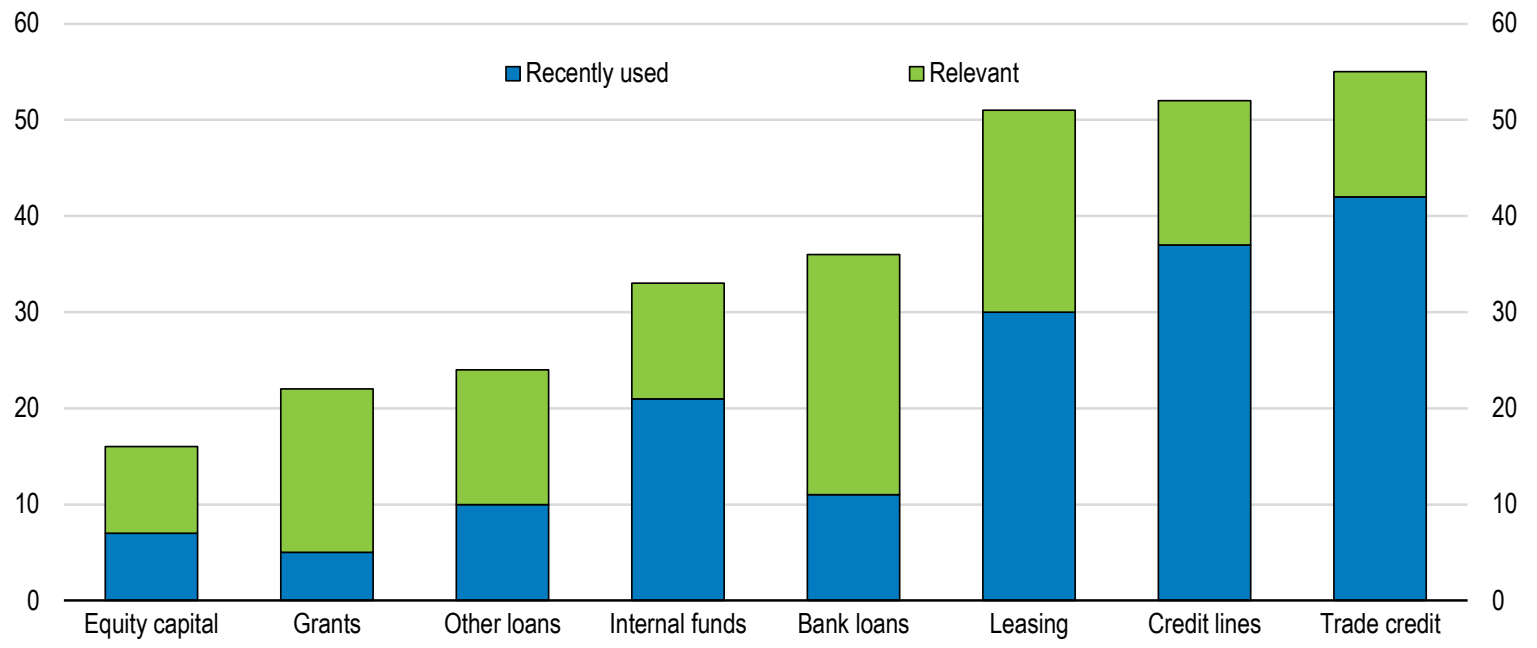

Note: Based on the Survey on the Access to Finance of Enterprises (SAFE), where companies were asked about the situation in the past 6 months (April - September 2018), published in November 2018.

Source: European Commission (2019), "SME access to finance conditions 2018 SAFE results - United Kingdom".

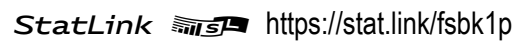

\section{Investigating new sources of financing for digital firms}

Young firms with intangible assets face longstanding difficulties accessing finance (Demmou et al., 2020). In addition to the information asymmetries common in SME finance markets, the value of intangible assets, even when registered, is also often not properly recognised and hard to use as a collateral. Yet, firms with intellectual property (IP) are found to have lower rates of default and loss than those without. IPO and British Business Bank (2018) identified four main barriers to using IP as collateral to secure debt finance: banking regulation, legal enforceability, valuation and liquidity. Solving these market failures would benefit small innovative companies and lenders. Budget 2018 put in place support to encourage more companies to use their IP to access finance, and work with banks to improve their awareness of the opportunities and true credit risk associated with such lending. 
Unlocking intellectual property as a source of collateral for finance and increasing the ability of IP-rich firms to make productivity-enhancing investments could be very positive for the UK economy. A prerequisite would be to encourage SMEs to register their IP if this form of lending is to function effectively. A number of other countries have explored the potential for IP-backed finance, with mixed results. New digital financing solutions, such as peer-to-peer lending and crowdfunding, as well as more recent innovations like initial coin offerings (ICOs), may also help, but require further study to assess overall benefits and risks (OECD, 2018b). As the issue is likely to gain importance with the rapid digital transformation of the economy, it would be useful to examine the relative benefits of these different options in the UK financial and banking environment.

\section{Maintaining low barriers to trade and competition}

The COVID-19 crisis has hit severely trade in services, in which the United Kingdom is highly specialised (OECD, forthcoming).

\section{Low barriers to service trade are key}

Kim, Mourougane and Baker (forthcoming) suggest that high barriers to international trade and investment reduce productivity while freer trade boosts productivity across countries and at the sectoral and firm level in the United Kingdom (Box 4). Entry barriers allow incumbent firms to gain market power and delay innovation, while frustrating the development of more innovative entrants. Global value chains increase those costs, which percolate down the supply chain. The costs of a policy environment that reduces competition from new entrants, including foreign firms, is ultimately borne by consumers and downstream business firms, which pay higher prices and enjoy less choice than they would in more open markets. There is also evidence that competition drives up the real wage and can force the least productive nontrading firms to exit, thus increasing average productivity (Ghironi and Melitz, 2005; Bloom, Draca and van Reenen, 2016). Low barriers to trade and competition will be particularly important to facilitate the adaptation of the country to a post-COVID-19 environment, with new working, production and consumption patterns.

Foreign-owned firms and exporting firms in the United Kingdom are on average more productive than domestically-oriented firms, reflecting in part inherent characteristics of those firms. On average productivity of foreign-owned firms is twice the productivity of domestically-oriented firms, and the gap is particularly large in the service sector (Haldane, 2017). Firms that export are on average 15\% more productive than domestically-oriented firms. This gap has been increasing over time, especially in the service sectors (Table 1).

\section{Table 1. Productivity gaps between UK exporting and non-exporting firms}

Per cent

\begin{tabular}{l|c|c|c|c|c}
\hline & \multicolumn{3}{|c|}{ Average productivity growth } & \multicolumn{3}{c}{ Gap between exporting-non exporting firms } \\
\hline & $2008-2016$ & $2000-2008$ & 2016 & 2008 & 2000 \\
\hline Exporting & 0.8 & 3.0 & 14.9 & 9.0 & 7.0 \\
\hline Non-exporting & 0.1 & 2.8 & & & 6.4 \\
\hline Services, exporting & 0.2 & 3.1 & 14.9 & 8.2 & \\
\hline Services, non-exporting & -0.5 & 2.8 & & & \\
\hline
\end{tabular}

Source: Calculations using ORBIS.

Keeping low barriers to trade and competition in the UK service sectors, will create a more supportive environment for strong productivity performance than in other countries (Figure 26). In 2019, the United Kingdom was among the top ten countries with the most open markets for service trade (excluding 
movement of natural persons). Barriers are especially low vis-à-vis European countries which continue to have access to the EU Single Market. This advantage is large when sectors are not covered by multilateral trading system (air transport), only partially covered (maritime transport), or in regulation-intensive sectors such as legal services, engineering or architecture.

The sectoral cross-country estimates reported in Box 4 suggest that an increase in the stringency of barriers to trade and competition from the current low levels for intra-EU trade to the higher levels currently faced by non-EU countries could depress sectoral hourly labour productivity by $2 \%$ to $5 \%$ in the long term in most service sectors (Table 2). The impact would vary across sectors, with transport and storage, professional scientific and technical activities and finance and insurance being the most affected. The magnitude of the impact depends both on the increase in trade barriers this implies for each sector, the current difference between intra-EEA and extra-EEA barriers, and on the pre-existing openness of each sector.

\section{Box 4. Explaining productivity developments: insights from sectoral and firm-level data}

Kim, Mourougane and Baker (forthcoming) draw on international and UK cross-sectoral and firm-level estimates and investigates the policy levers that could help to boost productivity in the United Kingdom.

Productivity growth is modelled as a function of policies and regulations and controls. The relation is estimated for both real labour productivity and multifactor productivity using dynamic OLS (DOLS) on a panel of 17 sectors over the period 1998-2017 for the sectoral estimates. Estimates are computed for the United Kingdom only and for a sample of 12 European countries. Firm-level analyses are undertaken for the United Kingdom over a sample of around 250000 firms. Results appear to be robust to a wide range of tests (Kim, Mourougane and Baker, forthcoming).

The main findings are:

- Barriers to trade and investment appear to be a determinant of productivity growth in the long term (Table 2). This is consistent with Égert and Gal (2017), which is based on aggregate productivity across a wider set of OECD countries.

- Spending on R\&D and human capital also play an important role, though their effects depend on the way those variables are measured.

- The magnitude of the impact is estimated to differ across sectors, depending on the degree of openness and the job intensity.

\section{Table 2. Long-run determinants of productivity growth}

\begin{tabular}{|c|c|c|c|c|c|}
\hline & \multicolumn{2}{|c|}{$\begin{array}{c}\text { UK - Firm-level data } \\
\text { (ORBIS) }\end{array}$} & \multicolumn{2}{|c|}{$\begin{array}{c}\text { UK - Sectoral level } \\
\text { (ONS) }\end{array}$} & \multirow{2}{*}{$\begin{array}{l}\text { OECD Sectoral level } \\
\text { (STAN) } \\
\text { Labour productivity }\end{array}$} \\
\hline & Labour productivity & MFP & Labour productivity & MFP & \\
\hline Barriers to trade and investment & $-0.766^{* *}$ & $-0.557^{* * *}$ & $-0.137^{* *}$ & $-0.165^{\star *}$ & $-0.146^{* *}$ \\
\hline R\&D spending & $0.032^{\star * \star *}$ & $0.029^{* \star *}$ &. &. & $0.098^{* *}$ \\
\hline Human capital & .. & .. & $0.265^{\star *}$ & $0.298^{* *}$ & $0.218^{\star *}$ \\
\hline
\end{tabular}

Note: MFP stands for multi-factor productivity. Estimates at the firm and sectoral levels are not comparable.* ${ }^{* *}$ represents significance at the $95^{\text {th }}$ percentile, ${ }^{* * *}$ represents significance at the $99^{\text {th }}$ percentile. In almost all cases, the captured effect is indirect (via an interaction term). Source: Kim, Mourougane and Baker (forthcoming).

Maintaining low barriers to trade vis-à-vis EU and other trade partners will also be key for market openness in the digital area as services play a crucial role in enabling digital trade transactions. Trade in digital 
services represents a high share of total exports in the United Kingdom, well above the OECD average. This reflects to some extent the relatively low level of barriers to digital trade and investment in the United Kingdom (Figure 27). Looking at specific measures, restrictions related to infrastructure and connectivity are in line with those of the best performing countries. The United Kingdom appears to be very open in terms of payment system and intellectual property rights. Local presence is required in order to provide cross-border services in the United Kingdom. Such a restriction exists in Australia, but not in Norway, which are best performers in this area. Regarding electronic transactions, the national contract rule for crossborder transaction deviates from internationally standardised rules. Most countries follow a similar approach.

Figure 26. Restrictions on trade in service sectors will rise when the United Kingdom leaves the EU Single Market

Services Trade Restrictiveness Index, scale from 0 to 1 (most restrictive), 2019

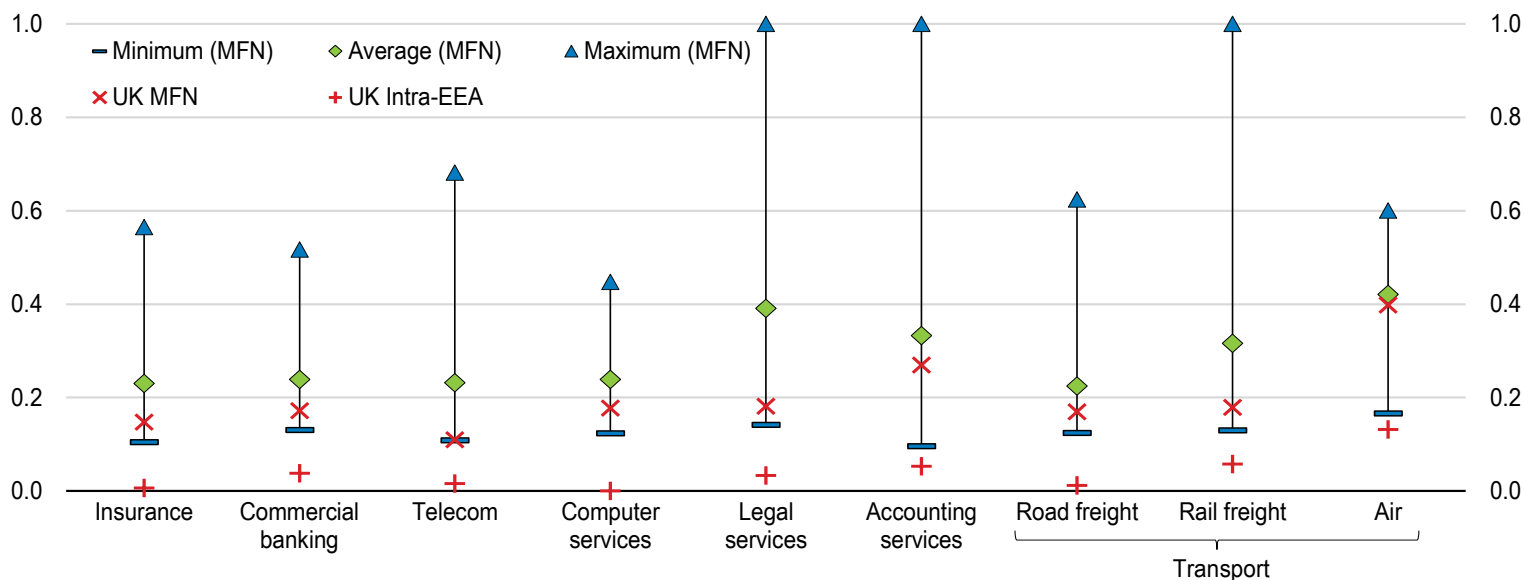

Note: STRI are calculated on the basis of the STRI regulatory database which contains information on regulation for the 37 OECD Members, Brazil, China, Costa Rica India, Indonesia, Malaysia, Russia, Thailand and South Africa. The Intra European Economic Area STRI covers 25 countries and 22 sectors. For more methodological information, refer to Benz, S. and F. Gonzales (2019) "Intra-EEA STRI Database: Methodology and Results", OECD Trade Policy Papers, No. 223.

Source: OECD (2020), "Service Trade Restrictions Index by services sector" and "Intra-EEA Services Trade Restrictiveness Index" in OECD Industry and Services Statistics (database).

StatLink त्ञाs https://stat.link/wdqjeo

Against this background, the United Kingdom should seek to maintain open service trade with the European Union. The Political Declaration states that the objective will be that of a liberalisation of service trade "well beyond WTO" building on recent EU free trade agreements. The objective is to ensure that services providers and investors are treated in a non-discriminatory manner, including with regard to establishment. There is also a willingness to achieve voluntary regulatory cooperation and "good regulatory practices", as well as "appropriate arrangements" for mutual recognition of professional qualifications and temporary entry and stay of natural persons for business purposes (European Union and UK Government, 2019). In the transport sectors, both parties agree to aim for a comprehensive air transport agreement, comparable market access in both markets for road transport operators and bilateral arrangements for cross-border rail services. Connectivity in the maritime transport sector is planned to be based on international law. In the financial services, the United Kingdom would get a third country treatment, based on equivalences. 
Table 3. Moving from EU to non-EU in restrictions to service trade would reduce long-term productivity in the service sectors

Difference to baseline, per cent

\begin{tabular}{l|c|c|c|c|c}
\hline & $\begin{array}{c}\text { Wholesale \& } \\
\text { retail; trade, motor } \\
\text { trade, motor } \\
\text { vehicle repair }\end{array}$ & $\begin{array}{c}\text { Transport \& } \\
\text { storage }\end{array}$ & $\begin{array}{c}\text { Information \& } \\
\text { communication }\end{array}$ & $\begin{array}{c}\text { Finance \& } \\
\text { insurance }\end{array}$ & $\begin{array}{c}\text { Professional } \\
\text { scientific and } \\
\text { technical } \\
\text { activities }\end{array}$ \\
\hline Increase in barriers & 0.1 & 0.2 & 0.2 & 0.1 & 0.2 \\
\hline Effect on productivity & \multicolumn{1}{|c|}{} & & & \\
\hline UK sectoral & {$[-0.4 ;-1.3]$} & {$[-0.8 ;-2.7]$} & {$[-0.5 ;-1.7]$} & {$[-0.8 ;-2.6]$} & {$[-1.1 ;-3.5]$} \\
\hline Cross-country sectoral & {$[-1.1 ;-2.1]$} & {$[-2.3 ;-4.4]$} & {$[-1.2 ;-2.3]$} & {$[-1.6 ;-3.1]$} & {$[-2.6 ;-4.9]$} \\
\hline
\end{tabular}

Note: In the simulation, restrictions to service trade raise from the intra-EU level to the most-favoured nations (MFN) level. The industrial classification is based on the UK Standard Industry Classification (SIC). UK specific elasticities have been estimated on a relatively small sample of observations and should thus be treated with care.

Source: Calculations using Kim, Mourougane and Baker (forthcoming).

Figure 27. Restrictions to trade in digital services are currently low in the United Kingdom

Digital Services Trade Restrictiveness Index, scale from 0 to 1 (most restrictive), 2019

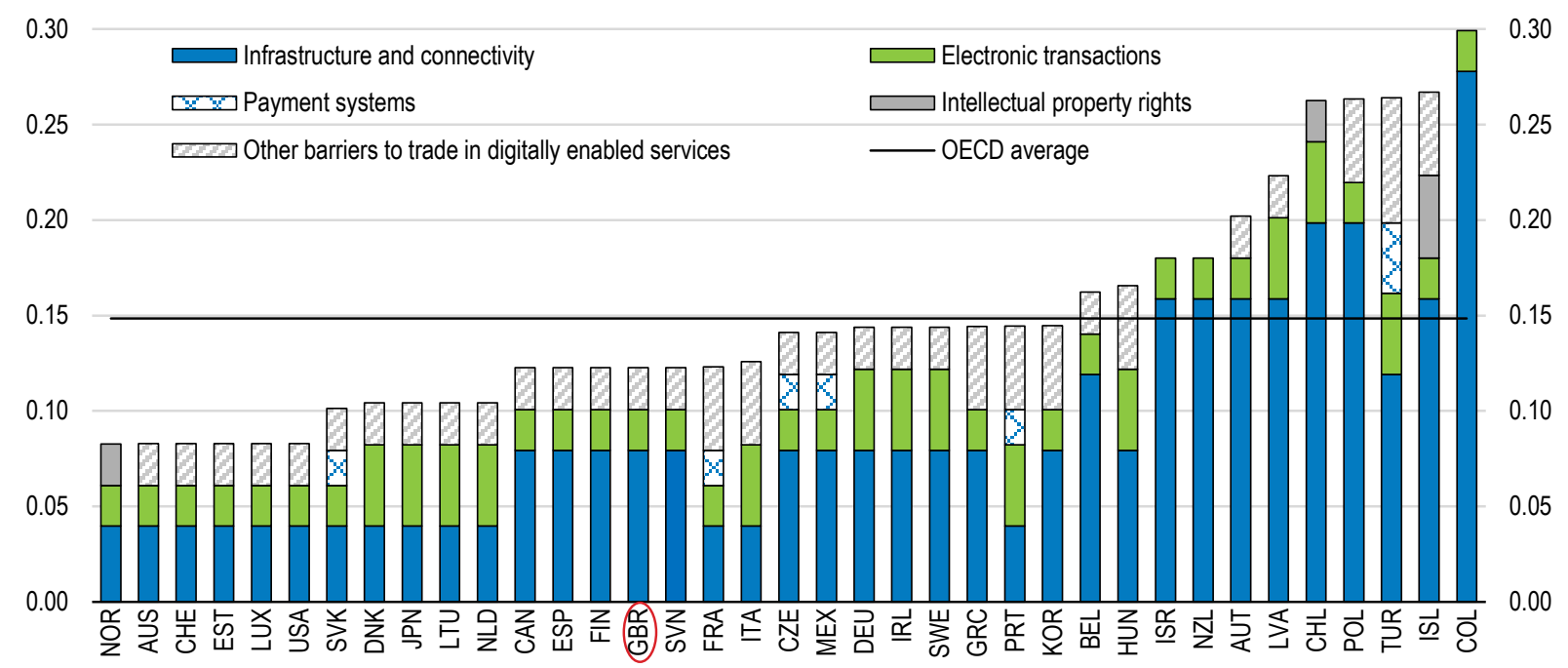

Source: OECD (2020), OECD Services Trade Restrictiveness Index (database).

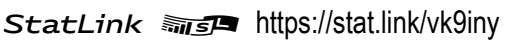

Reaching an agreement with the European Union will be essential. A no-deal exit could have damaging effects both in the short and in the long term, that will compound with employment losses from the COVID19 crisis (OECD, 2020a). Alongside negotiations to get a comprehensive deal with the European Union, the United Kingdom could seek to reinvigorate the plurilateral Trade in Services Agreement (TiSA) to ease services market access, although success in this area will also depend on the willingness of other countries to restart the process. 


\section{Refining business regulations and the competition framework to adapt the digital} transformation

Past experience has shown that the same principles of competition apply during times of recession as during times of economic expansion. The United Kingdom is estimated to have the least restrictive regulatory barriers to competition. Like many OECD countries, however, the country is experiencing deep structural changes which may require refinements to the competition framework. The UK competition authority has adopted a flexible approach to cope with the COVID-19 crisis and adjusted its working conditions as the situation develops (CMA, 2020).

Following the 2008 financial crisis, there have been mounting signs of increasing mark-ups and declining firm entry and exit rates in many OECD countries (Calligaris, Criscuolo and Marcolin, 2018; Calvino and Criscuolo, 2019). Studies also point to an increase in industry concentration in Europe, but less pronounced than in the United States, as well as an increasing rate of mergers and acquisitions (Bajgar et al., 2019). Focusing on the United Kingdom, the Resolution Foundation (2018) shows that there have been different phases since the early 2000s. Concentration in the United Kingdom rose by a small amount in the 2000s, increased sharply during the financial crisis and fell back more recently. To a large extent, the rise in concentration reflects a global trend, which is particularly marked in digital intensive sectors (Calvino and Criscuolo, 2019; De Loecker et al., 2018). The combined features of economies of scale and scope, killer takeovers (whereby a large incumbent absorbs a potential competitor), strong network effects, and restrictions to consumer switching and multi-homing mean that many digital platform markets have tended towards high levels of concentration.

A high degree of competition in digital markets can have benefits and limits. A small number of dominant firms may be more efficient, on average, to deliver better and more innovative products to consumers, as they benefit from network effects. But, this can raise effective prices for consumers, reduce choice, or impact quality. It can also be harder for new companies to enter or scale up. The most productive firms may become more difficult to challenge, especially in a digital environment where intangible firm-specific assets (such as tacit knowledge, data and algorithms) are an increasingly central source of value. This risks undermining business dynamism and could ultimately affect productivity. It could also impede innovation via lower contestability as larger companies have less to fear from new entrants. Finally, it can create monopsony positions and lead to a reduction in the labour share with an associated increase in inequality (OECD, 2019f). Another concern is related to the potential harm to firms that are reliant on digital platform markets to deliver services and could be particularly vulnerable to exploitation by dominant tech firms. Overall, benefits and downsides of competition can create a trade-off where the potential dynamic costs of a lack of competition in digital markets outweigh the static benefits from having a few large players with scale and network effects.

The United Kingdom has been leader in initiating a reflection on these issues and an independent expert panel on digital competition has put forward recommendations to ensure markets remain competitive as the economy becomes more digital (Digital Competition Expert Panel, 2019). One of the main recommendations is to enable greater personal data mobility and systems with open standards so that consumers can change service providers as they see fit (Box 5).

The potential barriers to entry in established digital platform markets mean that they cannot generally be considered freely contestable: the largest incumbents can exert significant market power over their users and may not be required to deliver the same level of positive outcomes as they would if facing normal competitive market conditions. OECD work shows that a broader set of considerations than current competition are needed to account for the specificities of digital markets (OECD, 2018c). Benato et al. (2019) also suggest that ex-post evaluation of the innovation impact of mergers is a feasible and worthwhile task (conditional on data availability). 
According to the Digital Competition Expert Panel report, merger assessments should be made more forward-looking and adopt a broader approach to merger assessment, including an 'balance of harm' evaluation of the overall economic impact of mergers - taking into account the magnitude as well as likelihood of impacts. The Government has announced that changes to merger policy will be subject to consultation. Given the novelty of the process, it will be important that the new approach is widely understood and offers a high level of predictability. In addition, existing antitrust law in digital markets has been used very infrequently and cases have moved too slowly. The antitrust enforcement regime should be updated to enable greater use of interim measures to prevent harm to competition during a pending antitrust investigation. The UK Competition Authorities (CMA) welcomed the conclusions of the expert panel report and responded by launching a Digital Markets Strategy in June 2019, setting out how it will continue to protect consumers in rapidly developing digital markets, while fostering innovation (CMA, 2019). It has now concluded a market study into online platforms, with recommendations in line with those of the expert panel report.

\section{Box 5. Main recommendations of the Digital Competition Expert Panel}

On 13 March 2019, a panel of independent experts, led by Professor Jason Furman, formulated recommendations to the UK Government. This box reports the main strategic conclusions of the panel.

\section{Establishment of a "digital markets unit" (DMU)}

The panel calls for the establishment of a DMU, which would be an independent body and would be given the remit of using tools and frameworks that will support greater competition and consumer choice in digital markets.

\section{Changes to UK merger control law and policy}

These include updating the merger assessment framework to provide more opportunities to intervene and to focus attention on technological developments and the possible loss of "potential competitors" as well as actual competitors; designating certain companies with "strategic market status" and requiring them to notify the competition authority (CMA) of "all intended acquisitions"; and a "balance of harm" merger test allowing the CMA to be able to weigh up (i) the magnitude and likelihood of harm from losing a rival and (ii) the magnitude and likelihood of potential benefits to consumers from efficiencies.

\section{Greater use of interim measures and revising applicable appeal standards}

The report suggests that the CMA should prioritise consumer enforcement work in digital markets, and should complement this with sufficient information gathering powers applicable to the digital economy.

In particular, it recommends that the antitrust enforcement regime should be updated to enable greater use of interim measures to prevent harm to competition during a pending antitrust investigation. In addition, appeal standards should be more closely aligned with the standards for judicial review and the ability to adduce new evidence in the course of an appeal should be removed.

\section{A global approach to digital enforcement}

The report concludes by calling for a more integrated global approach to the digital economy, including ensuring the effectiveness of remedies.

In June 2019, a long-term strategy on adapting the regulatory framework to technological innovation was published (HM Government, 2019). It proposed to introduce a new Regulatory Horizon Council to advise 
on rules and regulations that may need to change to keep pace with technology; a digital Regulation Navigator to help businesses find their way through the regulatory landscape and bring their ideas to market; a review of the Regulators' Pioneer Fund, which backs projects that are testing new technology in partnership with the regulators in a safe but innovative environment; and a partnership with the World Economic Forum to shape global rules on innovative products and services. In particular, the United Kingdom has developed a regulatory sandbox for fintech firms, Project Innovate, which provides a structured and controlled environment for firms to test innovative propositions in the market. This can encourage experimentation and new business models by promoting the flexible approach to regulation (OECD, 2019c). Overall, these proposals reach a good balance between the need to reform the regulatory landscape while preserving some flexibility given the uncertainty around the nature of emerging products and firms. Its focus on evaluation is particularly welcome.

\section{Easing land-use regulations}

Land-use regulation in the United Kingdom has long restricted the availability of land for urban uses, including land for retail. Regulations of retail development in England have been restrictive since 1947 and tightened decisively in 1996 with the introduction of 'Town Centre First' (TCF) policies which restrain the ability of retailers to choose locations and sites. Haskel and Sadun (2012) also suggest that planning policies led to a loss of $0.4 \%$ a year in firms' productivity from 1997 to 2003.

In the past two years, a revised National Planning Policy Framework (NPPF) was published and further liberalising reforms to the planning regime were introduced. In particular, the "shops" use class will be amended to ensure it captures current and future retail models and introduce a new permitted development right to allow shops. In addition, the existing right that allows the temporary change of use of buildings from two to three years will be extended to give businesses sufficient time to test the market with innovative business ideas. Further relaxing regulatory constraints will help to support the recovery through a better allocation of resources, improve matching of supply to consumers' preferences and support productivity growth. A consultation process on the "The Planning for the Future" aims at discussing reforms of the planning system to streamline and modernise the planning process.

\section{Ensuring basic skills in a modern workplace after the COVID-19 crisis}

\section{Retraining low-skilled workers is a double dividend policy following COVID-19}

With the COVID-19 crisis, unemployment is expected to rise markedly in the next two years (OECD, 2020a). Many service workers face unemployment and uncertain prospects. The Government has shifted to a second phase of support, from a blanket protection of employment to measures favouring a shift to activities with greater growth prospects. Upskilling, re-skilling and lifelong training will play a key role to facilitate this transition and help these workers, together with those facing longer-standing challenges due to risk of automation and digital advances. Upskilling and training provisions for many service sector jobs need to focus on improving basic skills that would generally be useful across most jobs. Indeed, basic reading comprehension and numerical skills, as well as people and personal skills, were highlighted as areas where employers saw the most growth in terms of skill needs (Figure 28).

From an international perspective, the share of jobs at risk of automation is relatively low in the United Kingdom, in part reflecting the smaller share of manufacturing-related positions in the overall economy (Figure 29). While automation may be good to boost aggregate productivity, it can have a differentiated impact across sectors. Occupations that are most at risk are those where required skill levels are low and jobs held by individuals with higher levels of education are considerably less at risk (ONS, 2019). Specific segments of these sectors may however be hard to automate, while some high-skilled jobs can be more easily displaced by technology. The COVID-19 crisis has underscored the difference in the capacity of services sectors to adapt to new working arrangements. $53 \%$ of employees in the information and 
communication industry reported having ever worked from home in 2019 , as opposed to only $10 \%$ of employees within the accommodation and food services industry (ONS, 2020).

\section{Figure 28. Basic skills are lacking amongst applicants to new position}

Difference between 2017 and 2015

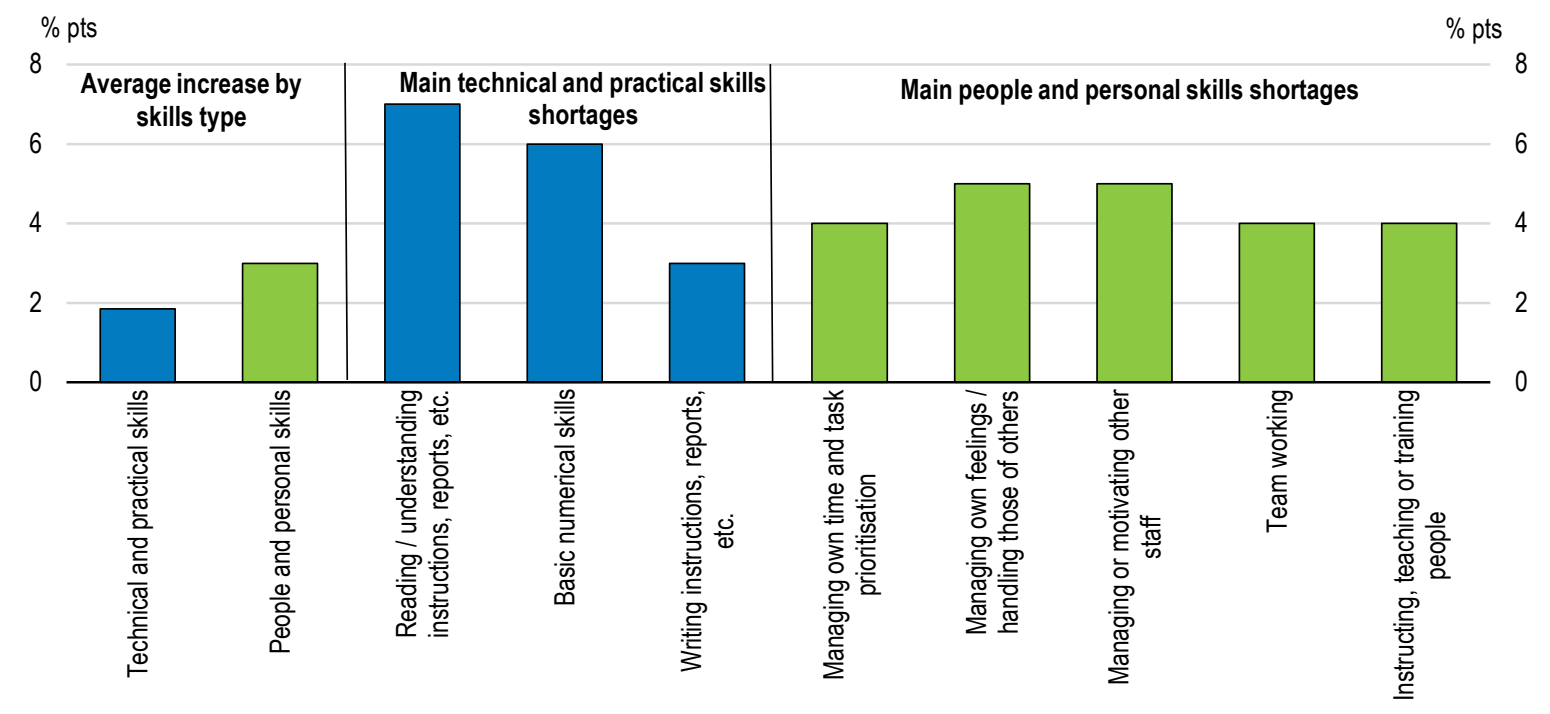

Note: Based on the UK Employer Skills Survey (ESS). Technical and practical skills are defined as skills required to perform the specific functions of a job role. People and personal skills are defined as skills required to manage oneself and interact with others in the workplace. The average numbers consist of 13 categories of specific skills for technical and practical skills and 10 categories for people and personal skills.

Source: IFF Research (2018), Employer skills survey 2017, Research report, August.

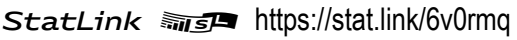

Figure 29. The share of jobs at risk is lower in the United Kingdom than in most countries but sizeable

The share of jobs at high risk of automation and significant change

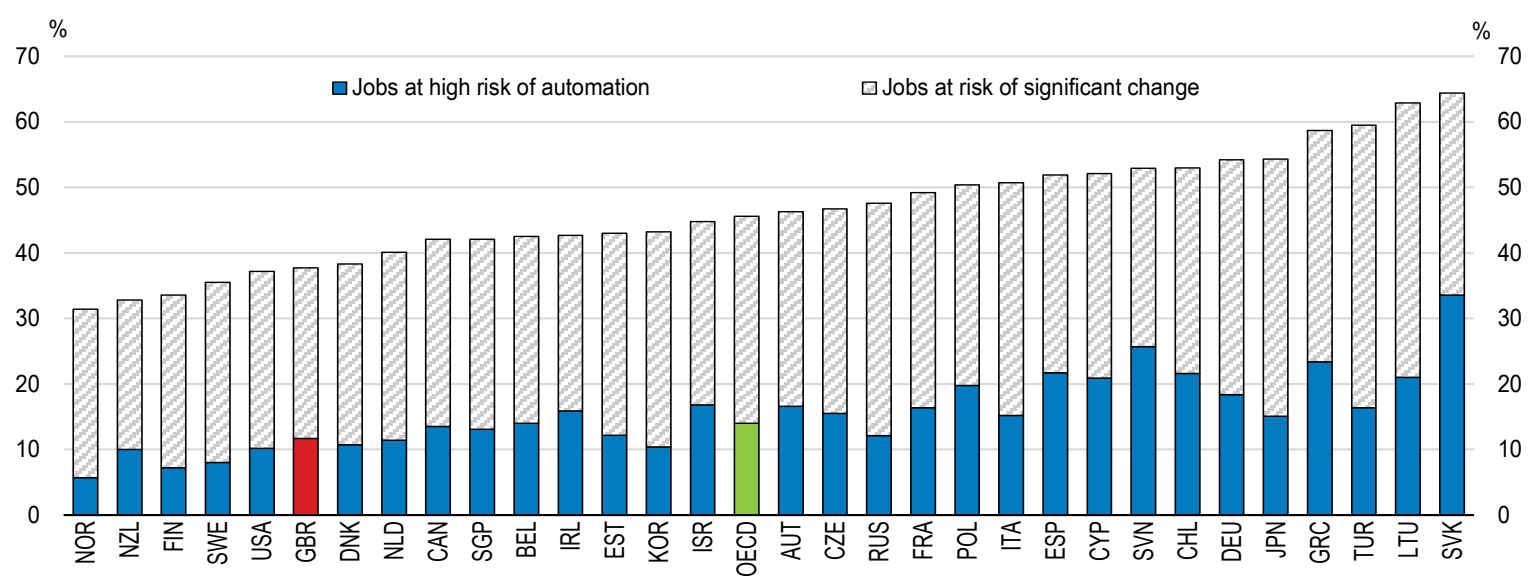

Note: Jobs are at high risk of automation if the likelihood of their job being automated is at least $70 \%$. Jobs are at risk of significant change if the likelihood is between 50 and $70 \%$.

Source: Nedelkoska, L. and G. Quintini (2018), "Automation, skills use and training", OECD Social, Employment and Migration Working Papers, No. 202, OECD Publishing, Paris. 
The hospitality and retail sectors represent an important example for how labour market dynamics for lowskilled individuals are being impacted by the COVID-19 crisis and shifts in modern working practices. These sectors collectively account for nearly a quarter of both total and private sector employment and for a large share of low-paid individuals. Employment growth in retail trade has been anaemic as consumer preferences continue to shift towards internet trading platforms and away from bricks and mortar stores and the hospitality sector has by far the highest share of workers with zero-hours contracts. Those patterns have accelerated since the lockdown during which a surge in e-commerce and consumption of digital products has been observed. Even though it is too early to know if recent trends are going to persist over time, it is unlikely that there will be a reversal of the pre-crisis move toward more online shopping.

Further education can play a useful role in helping people to retrain. It helps those who do not attend university after 18 years of age and adults in the workforce to up or re-skill with basic or intermediate skills that are vital in a changing labour market, alongside providing education for 16-19 year olds. While furthereducation institutions have experienced a fall in funding over the last decade, at the 2019 Spending Round the Government provided a GBP 400 million uplift to 16-19 year old funding, the largest increase for a decade. An independent panel recommended to reverse the decline in numbers of those getting post-18 education, with the cost being shared between taxpayers, employers and learners (Independent Panel, 2019). The focus should be in particular on strengthening technical education to redirect funding toward high-return courses, with more funding and a more coherent suite of technical and professional qualifications, together with a reform of the funding of further education colleges network. The Government allocated resources in the Adult Education Budget to fully-fund or co-funds some core skills, and fully fund basic digital skills. Advanced Learner Loans are also available to finance studies at a higher level. In the March 2020 Budget, the Government also announced GBP 1.5 billion over five years in capital spending to refurbish further education colleges, and plans to boost science, technology, engineering and maths teaching with GBP 270 million total capital spending for up to 20 new Institutes of Technology. In the Plan for Jobs, the Government provided new funding to support people to build the skills they need to get into work, with a substantial expansion of existing provision, providing funding to triple the number of traineeships and sector-based work academy placements, alongside further support for apprenticeship.

Following the COVID-19 crisis, the low participation in lifelong training in the United Kingdom compared to other high-income countries is a concern, particularly as it has been decreasing (Figure 30). Moreover, the United Kingdom has one of the highest gaps of training incidence between low-skilled individuals and workers of all skill levels (Figure 31). Some low-skilled workers face further constraints, in that their lack of basic skills can make it more difficult to meet the entry requirements of adult learning programmes (OECD, 2019g).

In the March 2020 Budget, the Government committed to a new GBP 2.5 billion National Skill Fund to improve adult skills, in part in response to the COVID-19 crisis. This is warranted though insufficient given the widespread job losses and need to retrain workers. OECD research estimates that around $1 \%$ to $4.5 \%$ of GDP in both direct and indirect training costs - the opportunity cost of attending the training -- would be needed alone to ensure the success of individuals to transition from occupations at high-risk of automation to those with a low risk (Andrieu et al., 2019). The upper range of the cost estimate would mean doubling the existing total training expenses which amounted to GBP 45.4 billion ( $2.2 \%$ of GDP) in 2015 (UKCES, 2016). The costs would be larger for high rather than low-skilled workers, as the former face larger opportunity costs. Although those opportunity costs are expected to fall in an environment of high unemployment, they are substantial and underline the need to allow individuals to continue working while attending their training. 
Figure 30. Participation in lifelong learning has declined

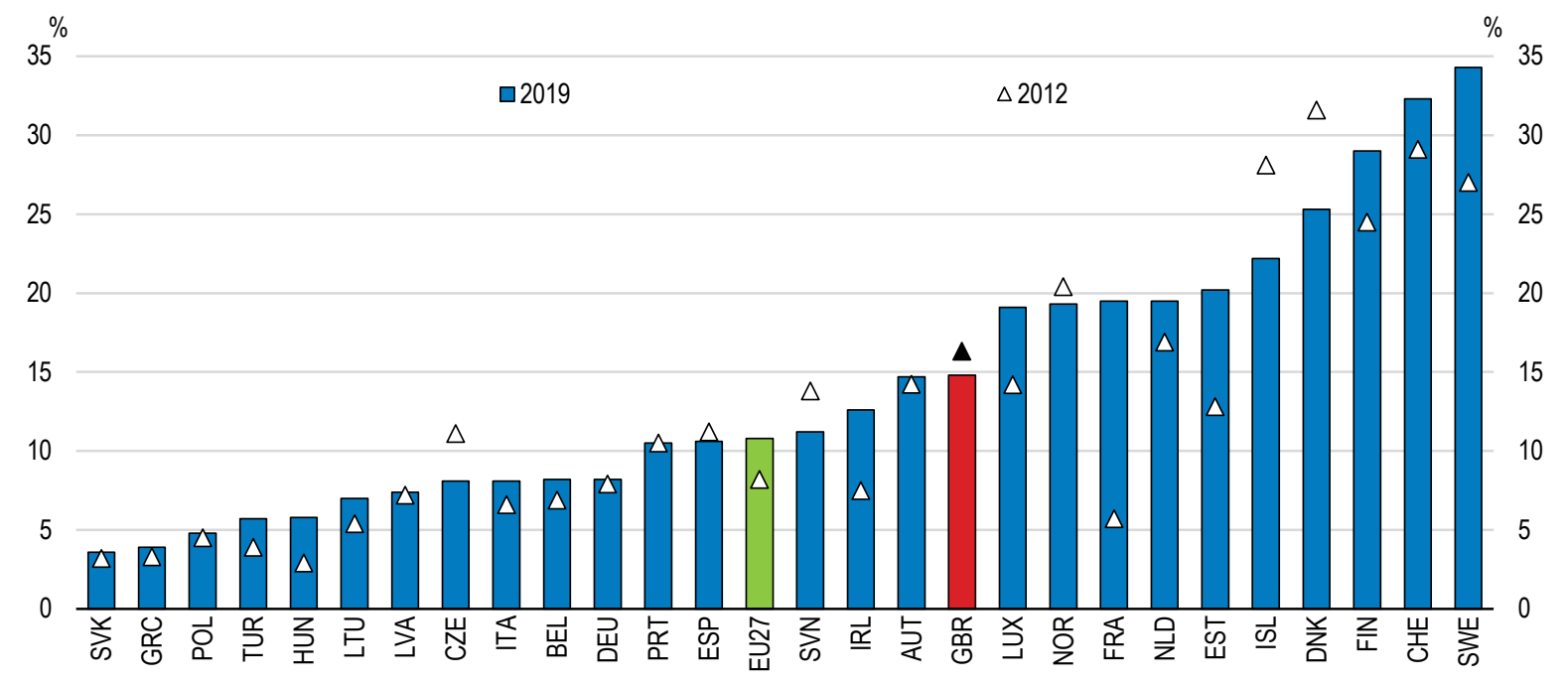

Note: The indicator measures the share of people aged 25 to 64 who stated that they received formal or non-formal education and training in the four weeks preceding the survey, over the total population of the same age group, excluding those who did not answer to the question. Adult learning covers formal and non-formal learning activities, both general and vocational, undertaken by adults after leaving initial education and training.

Source: Eurostat, based on the EU Labour Force Survey.

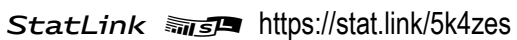

\section{Figure 31. Low-skilled workers receive less firm-based training}

Gap between training rates of low-skilled training workers ${ }^{1}, 2012$ or $2015^{2}$

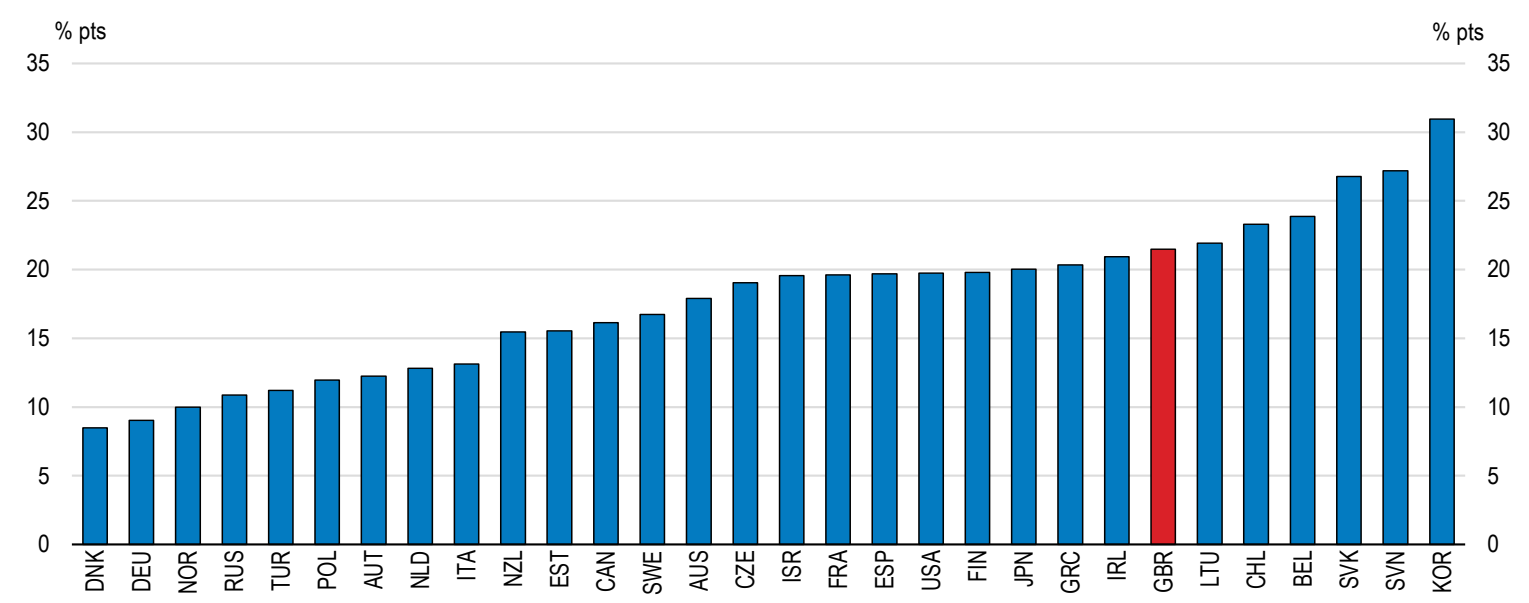

1. The percentages of trained people are calculated as the ratio of total employed persons displaying a given skill level and receiving training at least once in the year, over the number of a country's workers displaying a given skill level. Training refers to formal, on-the-job or both types. Low-skilled individuals refer to persons who have not completed any formal education or have attained 1997 ISCED classification level 1 to $3 C$ degrees (if $3 \mathrm{C}$ is lower than two years). Values are reweighted to be representative of the countries' populations. The total trained workforce is the proportion of workers who engaged in training at least once in the year.

2. Based on two rounds of the Survey of Adult Skills in 2012 and 2015.

Source: OECD (2019), Going Digital: Shaping Policies, Improving Lives.

StatLink :

With a more flexible and temporary workforce in the United Kingdom, firms may not be incentivised to invest in the skills and training of their staff, and lower-paid individuals in particular will find it difficult to pay 
for this training themselves. Differences in training participation between full-time permanent employees and own-account workers is the highest in the OECD (Figure 32). To this end, from 2020 onwards, adults who lack basic digital skills will be able to access specific skills training free of charge. The National Retraining Scheme, which aims at supporting workers' retraining, is being rolled out and is targeted to workers aged 24 and over, with a below-graduate level qualification and individuals who have lost their jobs due to automation and Artificial Intelligence.

\section{Figure 32. Own-account workers participate less in training}

Difference in training participation, full-time permanent employees minus own-account workers, 16-65 years-old, 2012 or 2015

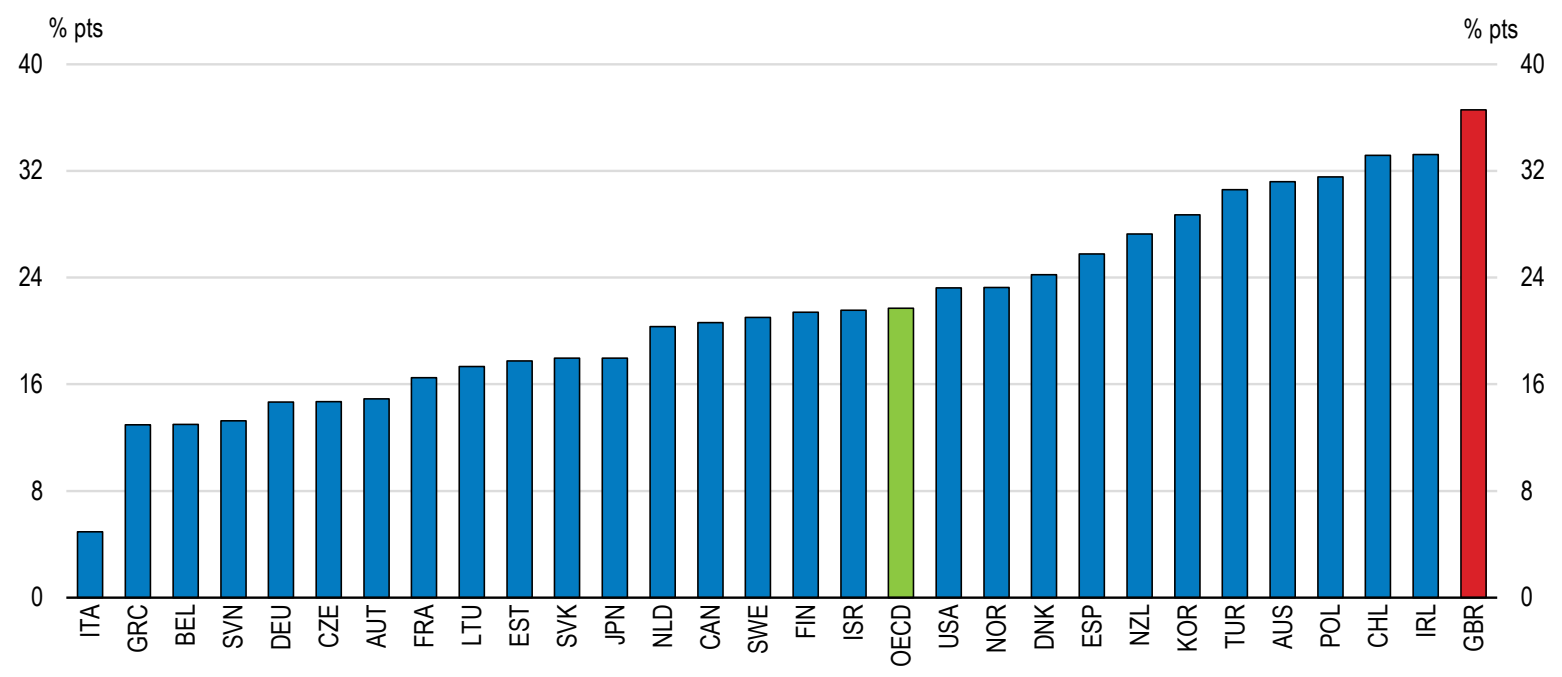

Note: Training participation is measured by the share of adults who participated in training over the previous 12 months. Source: OECD (2019), OECD Employment Outlook 2019: The Future of Work and Survey of Adult Skills (PIAAC).

StatLink הत्रा https://stat.link/cgdjw8

Introducing individually targeted programmes for low-wage and low-skilled workers would be an effective way to help service workers following the COVID-19 crisis and to encourage the participation in training of individuals in need of the training to adapt to workplace dynamics. Past UK and international experience can help to design the scheme (Box 6). To ensure that such a lifelong learning accounts system benefits the most vulnerable individuals, the scheme could focus on Universal Credit recipients (Taylor Review, 2017).

The new apprenticeship system in England, which focuses on a more rigorous quality assessment and longer programme lengths, is open to all levels and workers with low and middle-level qualifications have benefited from the scheme. At the same time, a sizeable portion of small businesses have indicated that the system remains cumbersome and difficult to engage with (Industrial Strategy Council, 2020). While the set-up of the scheme resulted in a relatively low take up of levy funds, there is a risk of exceeding the budget allocation, as employers are choosing higher-level and more expensive schemes (Industrial Strategy Council, 2020). There was a considerable drop in the number of total apprenticeship starts compared to the previous system, in particular in traditional sectors such as construction and retail (Resolution Foundation, 2019; Department of Education, 2020). Further reforms to the system should aim at ensuring that younger workers, individuals from disadvantaged backgrounds, and those with low skills are able to access high-quality apprenticeships to ensure that the system as a whole does not exacerbate existing biases in training and lifelong learning provision to higher skilled individuals (OECD, 2018b). 


\section{Box 6. Adult learning for displaced individuals and those with low skills}

Many OECD countries have implemented programmes with a goal of improving lifelong learning for disadvantaged individuals, especially for individuals with low skills or in other groups that tend to undertake low levels of training (like the self-employed). Below are some selected examples of how OECD countries are aiming at softening or eliminating the barriers to increased participation in adult learning, building on the 2019 OECD Employment Outlook.

- Belgium - The self-employed are eligible for training expense deductions, and a separate training subsidy exists that covers one third of training costs for vulnerable groups. In Flanders, Centres for Adult Education provide training through fully modular courses, including for a wide range of technical skills and languages.

- Estonia - A Degree Study Allowance is offered to employed and unemployed adults with insufficient or outdated skills, facilitated through the public employment services provider (PES). The monthly allowance to cover the costs is income dependent and only paid for skills that meet sectoral skills needs based on the assessment of the Qualifications Authority. The PES also implemented a Work and Study programme which included a training card/voucher system for employed persons at risk of unemployment and a training grant for employers to improve the skills of employees at risk of losing their jobs after the introduction of new technologies.

- Finland - The Change Training programme offers re-training options to dismissed workers during the nine months following the dismissal. The PES covers $80 \%$ of the training costs and firms cover the remaining $20 \%$. The Adult Education allowance provides income support during training for both employees and self-employed individuals when enrolled in a full-time training programme.

- France - Improvements in the recognition and certification of skills system (Validation des acquis de l'expérience - VAE) puts the obligation on firms to periodically inform employees about the VAE in the context of their mandated professional development assessment. The Individual learning account (Compte Personnel de formation) provides additional funding for individuals who are low-skilled.

- Luxembourg - The Digital Skills Bridge helps employees in companies facing major technological disruption to find new placement opportunities and to acquire new professional skills. Registered self-employed workers are offered training guidance and advice through professional associations. The Government provides wage compensation to self-employed workers taking education and training leave.

- Sweden - Job Security Councils provide specific transition services - including advice, training and business start-up support - to dismissed and soon to be dismissed workers. An education entry grant, in place since mid-2017, provides funds for low-qualified unemployed individuals to study at the primary or secondary levels.

\section{Upgrading management skills will improve the capability of firms to benefit from digitalisation}

Upgrading skills - both managerial and technical - would bring significant productivity dividends in the United Kingdom (Sorbe et al., 2019). The quality of management can play an important role in explaining productivity across different firms (Bloom et al., 2013) and in improving the ability of firms to adopt new technologies and to benefit from digitalisation (OECD, 2019g). Insufficient managerial skills can act as an obstacle in the ability of businesses to develop new business models, new organisational structures and new working methods (OECD, 2019c; Andrews, Nicoletti and Timiliotis, 2018). Furthermore, management 
and communication skills tend to earn a higher wage premium in digital work environments when compared to those in non-digital intensive industries (Grundke et al., 2018).

Management quality is of particular concern in the United Kingdom and has been singled out as one of the potential causal factors to the ongoing weakness in productivity growth (Haldane, 2017; Institute of Employment Studies, 2016a). Managers in the United Kingdom tend to have lower levels of formal education than in other countries, with the share of managers with at least a tertiary education well below the best performers (Figure 33). The issue seems to be concentrated in a long tail of poorly-managed firms (BIS, 2012).

In the United Kingdom, family-owned businesses account for around $70 \%$ of SMEs and nearly $80 \%$ of the retail/wholesale trade and hospitality sectors. The role that family connections play in management, in terms of ownership and family successions, can have important impacts on managerial quality and productivity growth. Managerial quality is lower on average in family-owned firms compared to other firms (Figure 34).

The inheritance tax scheme, which can in some cases benefit from a 100\% relief from the tax when passing down business assets, could be contributing to the prevalence of family-owned businesses with an indirect negative impact on overall managerial quality (LSE growth paper, 2017). The UK's Office of Tax and Simplification is reviewing the inheritance tax system to simplify tax filing and payments, but also to examine whether the current framework distorts business transfer decisions. If that is the case and given that ownership is often associated with management in family-owned businesses, it will be useful to eliminate or reduce these reliefs to lower incentives to maintain businesses within families.

\section{Figure 33. Management skills can be upgraded further}

Share of managers with tertiary education, 2017

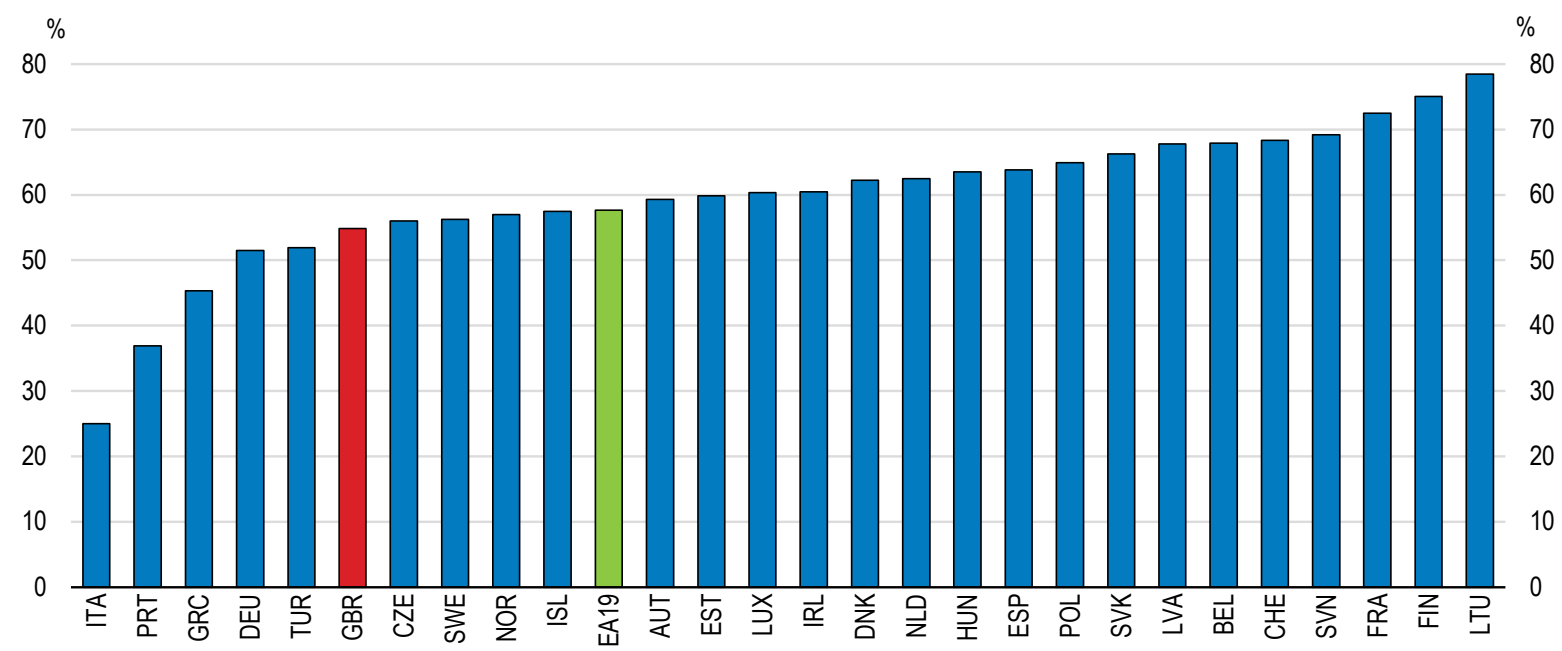

Note: Data refer to managers (group1) based on the International Standard Classification of Occupations 2008 (ISCO-08) and tertiary education (levels 5-8) based on the International Standard Classification of Education (ISCED 2011).

Source: Eurostat (2019), Employment and unemployment (Labour Force Survey) Statistics.

StatLink त्ञाIs https://stat.link/bjplfd

Encouraging management training would also help enhance management skills. There are numerous good-quality management schools and management training has improved through the increasing use of the apprenticeship programme to finance MBAs. However amongst the $68 \%$ of managers who received a training in SMEs, only 38\% received a training in leadership and management skills according to the 2018 
Small Business Survey. The Formação-Ação in Portugal is an example of training that focuses on improving management skills in SMEs.

\section{Figure 34. Managerial quality tends to be lower in family-owned firms}

Management score, by ownership type, scale from 0 to 1 (the most structured management practice), 2016

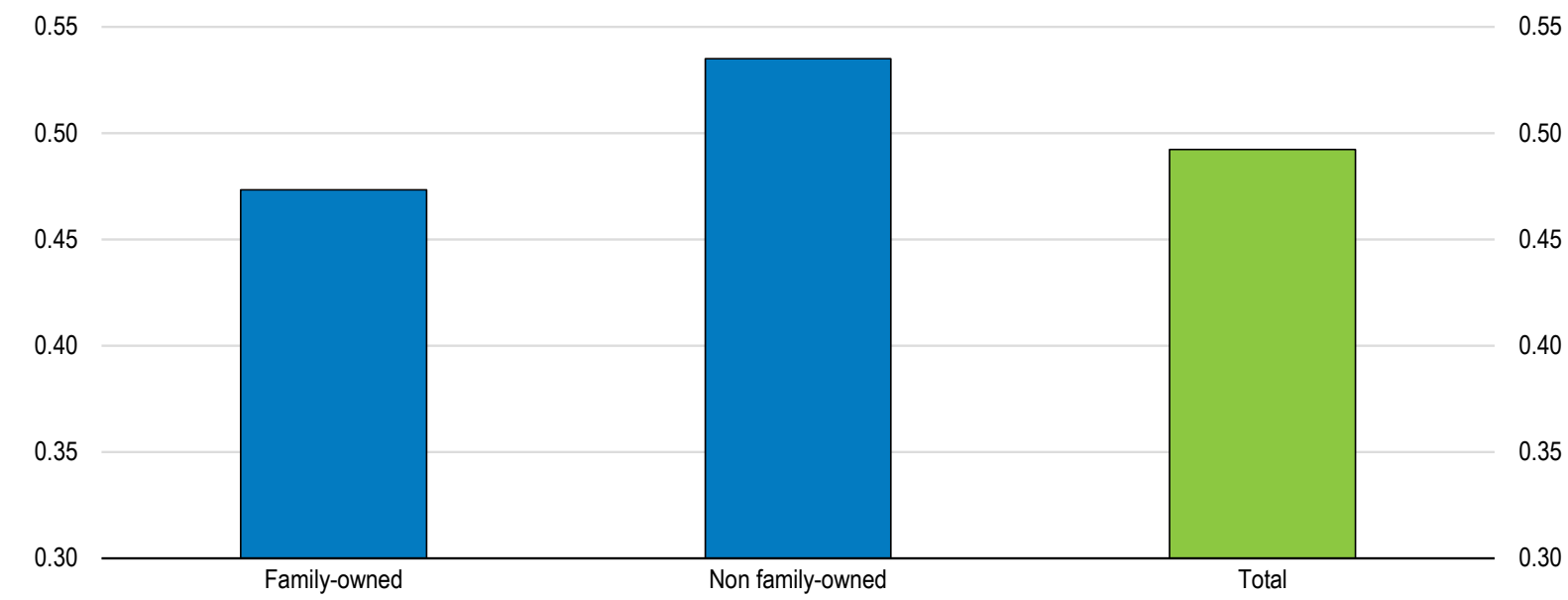

Note: Based on the Management and Expectations Survey (MES). The managerial quality is measured as the average management practice score of 12 categorical questions on quantitative and qualitative aspects of business' management practices. The sample covers businesses in production and services industries with at least 10 employees, excluding firms in agriculture, forestry and fishing, and financial and insurance activities, and results are weighted to reflect the population of firms.

Source: ONS (2019), Management practices and productivity in British production and services industries - initial results from the Management and Expectations Survey: 2016.

StatLink त्ञाज https://stat.link/mn5f6c

\section{Improving efficiency in the public sector}

\section{Productivity growth in the public sector has improved since the beginning of the decade}

While the health system has responded rapidly to the COVID-19 crisis, improving efficiency in the public sector, which accounts for $25.1 \%$ of value added in 2018 , is key at a time of increased pressure on services. Measuring efficiency in the public sector is fraught with difficulties and the ONS has been a leader in this area (Box 2.2). According to the ONS, productivity in the public sector grew since 2011 at faster rate than in the past. Those developments have coincided with spending cuts following the 2010 Spending Review (ONS, 2019b). Productivity growth increased in most public sectors with the exception of social care and social security administration. Healthcare and to a lesser extent education services contributed the most to productivity growth in recent years, reflecting their large weights in total government expenditure (Figure 35). Productivity growth in the public sector still remains modest compared to what can be observed in some other service sectors, but this may reflect the nature of the public services and measurement issues. ONS estimates point to stronger productivity growth when excluding sectors where productivity is very roughly measured. 
Figure 35. Health services contributed the most to productivity growth in the public sector in recent years

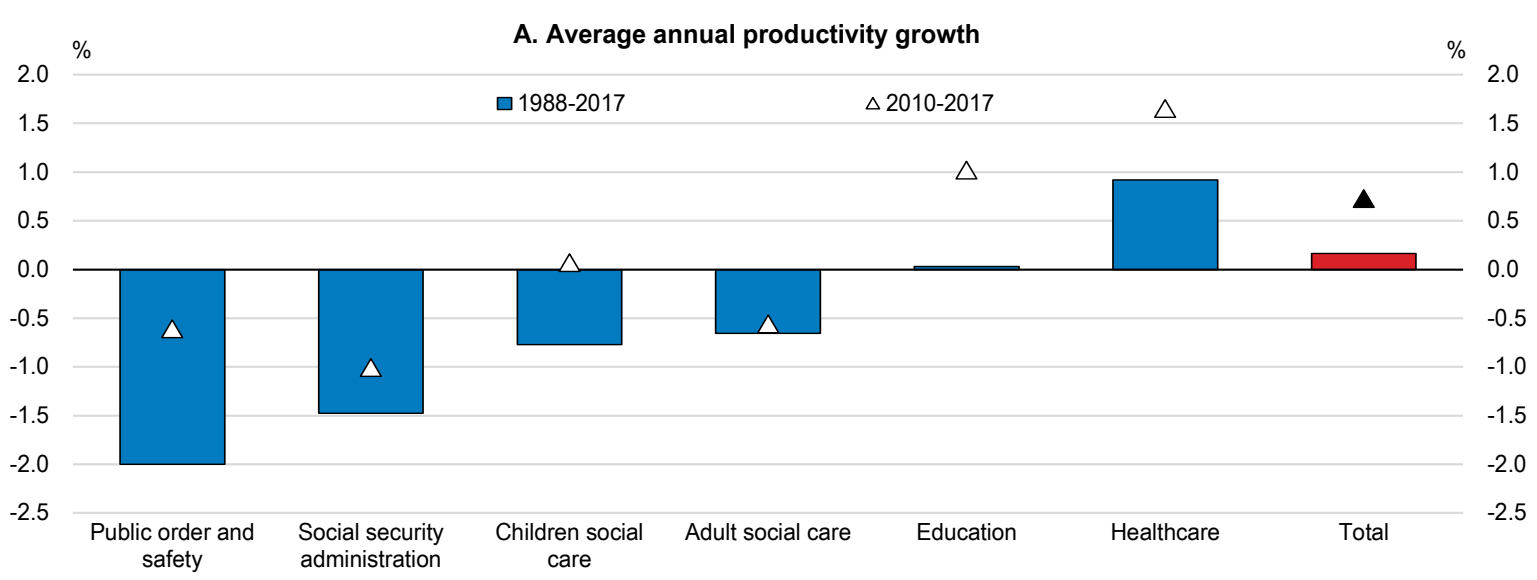

B. Growth rates and contributions to public service productivity growth ${ }^{1}$

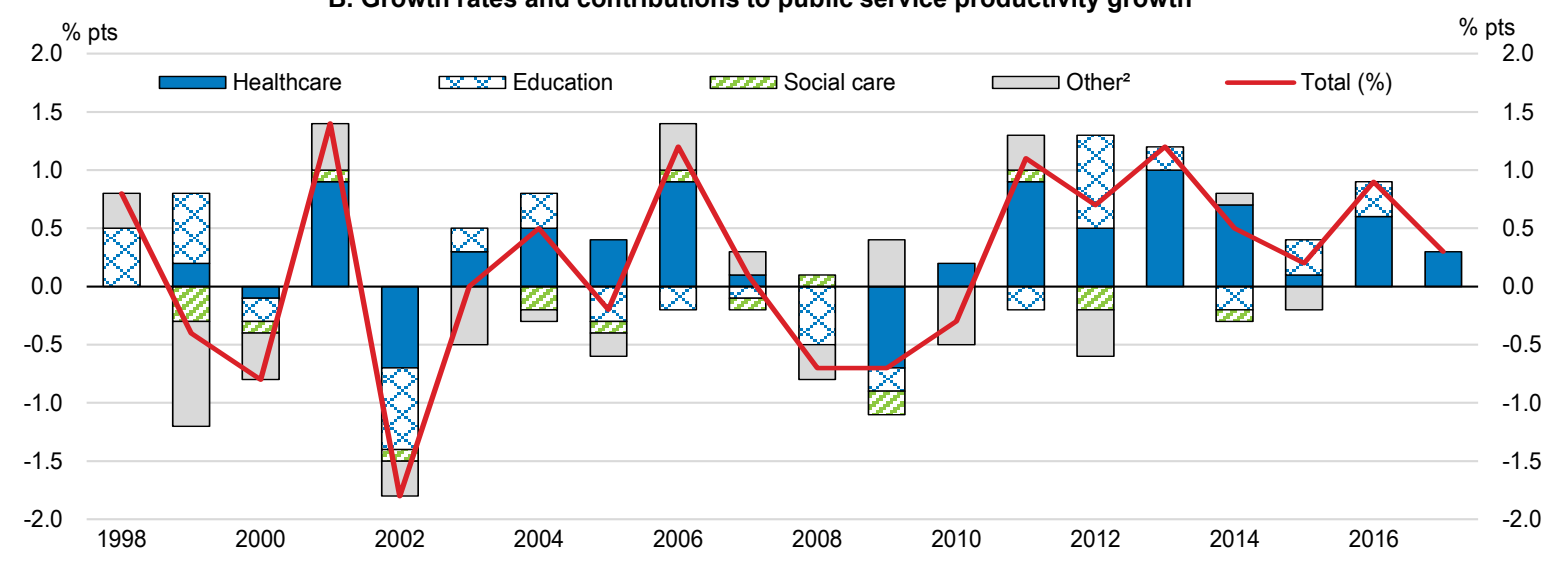

1. Contributions may not sum to total due to rounding.

2. Includes social security administration and public order and safety.

Source: ONS (2020), "Public service productivity: total, UK, 2017".

StatLink 제개 https://stat.link/k7pzil

\section{Further developing digital government}

The United Kingdom should seize the opportunity of the rapid digitalisation of the economy, which has played a critical role in the COVID-19 crisis, to further develop digital government. The OECD Open, Useful and Re-usable data (OURdata) Index show that, by 2017, the United Kingdom was doing better than most OECD countries in relation to the availability, accessibility, and re-use of open government data. However, results for 2019 indicate a decrease in the UK's score vis-à-vis other countries. The country has put in place an integrated online service through its one-stop platform GOV.UK, which will be updated to meet the requirements of the National Data Strategy. Nevertheless, the uptake of government services appears to be only average compared to other OECD countries (Figure 36).

The 2017 Government Transformation Strategy 2017-2020, and its 2018 update, focused on new technologies such as Artificial Intelligence and biometrics to support public service provision. Setting a long-term strategy to spur the digital transformation of the public sector is a step in the right direction. It can help to more fully integrate digital technologies in decision-making processes (OECD, 2019c). This 
also raises awareness on the fundamental behavioural shifts triggered by digitalisation to both public employees and private sector actors. The next step is to take concrete actions and implement the strategy.

The first priority is to improve the use of public procurement as a lever to raise the efficiency of public spending. There is no conclusive evidence that one model of ownership (i.e. public, private or mixed) is intrinsically more efficient than the others, irrespective of how efficiency is defined (UNDP Global Centre for Public Service Excellence, 2015). Instead the literature suggests that the efficiency of service provision depends on the type of services and other specific contextual factors (e.g. regulation, competition).

The COVID-19 crisis has underlined the capacity of the health system to swiftly adapt its process and react to the consequences of the pandemic. It has issued emergency procedures to respond to immediate needs. Beyond the crisis, procurement policies could play a decisive role in the government response to support the recovery (OECD, 2020e). The crisis has revealed the necessity to increase coordination and enhance flexibility, in the context of high uncertainties and fast changing environment. Lessons from the current crisis point to the need to re-think risks and contract management frameworks in future procedures (OECD, 2020e).

Procurement accounts for a third of public expenditure (OECD, 2017). The proportion of published procurement spending going to 25 strategic suppliers - companies that receive more than GBP 100 million in revenue a year from government contracts - has grown since 2012/13 (Institute for Government, 2018). Reasons behind this increase are unclear and it would be useful to review the competitive nature of the market and increase scrutiny of large outsourcing contracts.

Public procurement in the United Kingdom is currently governed by EU rules and this will change after the transition period. In the Political Declaration, the United Kingdom and European Union indicated they wanted to go beyond what they are committed to under the WTO Government Procurement Agreement. It will be important to maintain rules consistent with the principles of transparency, non-discrimination and equal treatment of the candidates. Making sure that procurement contracts encompass an environmental dimension will also help to achieve the country's environmental objectives.

\section{Figure 36. The uptake of digital government services is average}

Use of digital government services by individuals, \% of individuals aged 16-74, 2018 or latest year

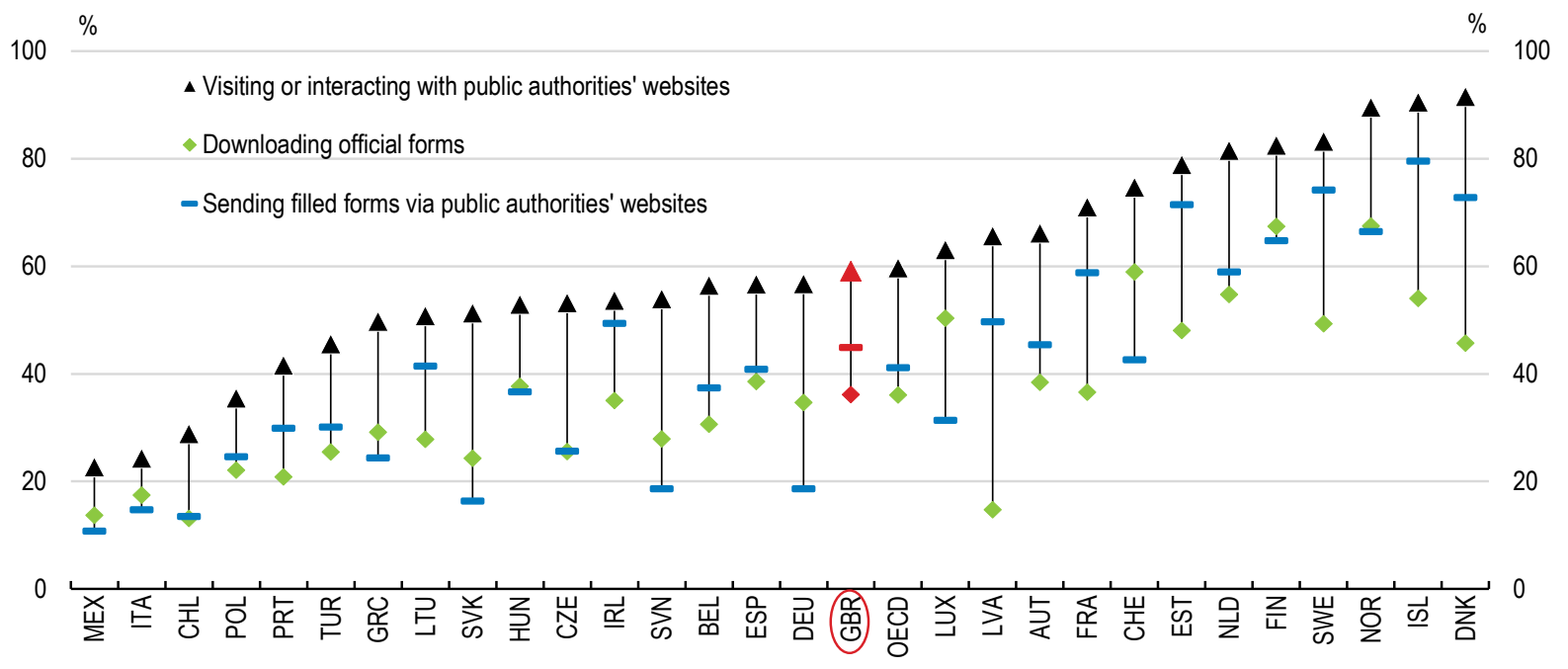

Source: OECD (2019), Going Digital: Shaping Policies, Improving Lives and OECD ICT Access and Usage by Households and Individuals Database (http://oe.cd/hhind). 


\section{8}

ECO/WKP(2020)37

The second priority is to foster innovation in the public sector, which is crucial for strengthening the government's capacity to respond to current and possible future challenges. The OECD draft Declaration on public sector innovation seeks to set out and gain agreement on some shared principles. Public sector innovation is a 'multi-faceted' phenomenon and can be about doing different things or doing things in different ways. As such the public sector can benefit from maintaining a portfolio of innovation activity and adopt a cross-ministry approach. This will allow to leverage on best practices across ministries to encourage public agents to innovate and set innovation at the core of the institution's objectives. An example of such an approach is the formation of the UK Policy Lab, which uses design, data and digital tools and acts as a testing ground for policy innovation across government, helping to drive change in many large projects and train civil servants in the use of experimental policy techniques. Given the multifaceted nature of public innovation and its changing nature over time, differing forms of support or enabling conditions to function well will be needed.

A third priority will be to improve public services' access to digital infrastructure. Public private partnerships could be useful. It is a way to benefit from the experience of private IT providers, while taking into account the specific objectives and ways of operating of the public sector. Such a partnership can also identify synergies. Steps in this direction have been taken with the GovTech Catalyst, which funds suppliers to solve public sector problems using innovative digital technologies. 


\begin{tabular}{|c|c|}
\hline MAIN POLICY FINDINGS & RECOMMENDATIONS (Key recommendations in bold) \\
\hline \multicolumn{2}{|c|}{ Ensure a favourable business environment } \\
\hline $\begin{array}{l}\text { The COVID-19 crisis has hit services trade. Productivity in the United } \\
\text { Kingdom relies on high trade integration with the European Union. } \\
\text { Services account for a large share of trade, but negotiations have } \\
\text { focused mostly on goods. }\end{array}$ & $\begin{array}{l}\text { Keep low barriers to trade and investment with the European Union } \\
\text { and others, particularly market access for the service sectors } \\
\text { including financial services. }\end{array}$ \\
\hline $\begin{array}{l}\text { The competition framework is well designed, and the United } \\
\text { Kingdom is currently one of the least restrictive countries in terms of } \\
\text { business regulations. The framework will need to be refined to adapt } \\
\text { to a fast changing environment. Stringent land-use regulations } \\
\text { prevent an efficient allocation of housing supply. }\end{array}$ & $\begin{array}{l}\text { Refine the competition framework to adapt it to the digital economy: } \\
\text { enable greater personal data mobility and systems with open } \\
\text { standards; adopt a broader approach to merger assessment including } \\
\text { an evaluation of the overall economic impact of mergers. } \\
\text { Ease-land use regulations to seek the right balance between } \\
\text { improving resource allocation and environmental and social concerns. }\end{array}$ \\
\hline $\begin{array}{l}\text { Raising productivity in services is key to support the recovery. } \\
\text { Productivity growth has underperformed compared to past business } \\
\text { cycles and to developments in other OECD countries. Low } \\
\text { investment and slow innovation rates are two factors behind weak } \\
\text { productivity performance. Adoption rates of new technologies lag } \\
\text { behind best performers. }\end{array}$ & $\begin{array}{l}\text { Prioritise digital infrastructure, particularly in deprived regions, in the } \\
\text { allocation of the planned increase in public investment. The } \\
\text { Government may invest directly in high-speed fixed networks or incentivise } \\
\text { private investment, including by competitive tendering, tax exemptions, low- } \\
\text { interest loans or lower spectrum fees. } \\
\text { Continue to boost direct funding to R\&D to raise innovation levels. }\end{array}$ \\
\hline $\begin{array}{l}\text { Young and small firms experienced financing constraints in the } \\
\text { aftermath of the virus outbreak. There is evidence of a gap in the } \\
\text { supply and use of long-term capital that is holding back firms from } \\
\text { growing to scale. }\end{array}$ & $\begin{array}{l}\text { Review the system of support to small firms in the light of the COVID-19 } \\
\text { crisis and to re-prioritise resources towards young innovative firms. } \\
\text { Continue to change existing investment rules to remove barriers for UK } \\
\text { pension funds to diversify their portfolios to increase the financing pool } \\
\text { available to young innovative firms, in light of the ongoing review. } \\
\text { Secure venture capital public funding over the long term and provide clarity } \\
\text { to investors in terms of how EU funding will be replaced. }\end{array}$ \\
\hline \multicolumn{2}{|c|}{ Improve skills and training } \\
\hline $\begin{array}{l}\text { The COVID-19 crisis will lead to widespread job losses, raising the } \\
\text { need to retain under-qualified workers, whose proportion is one of } \\
\text { the highest in OECD countries. Spending allocated to adult training } \\
\text { is low. Participation in lifelong learning has been declining in recent } \\
\text { years. Low-skilled workers receive less firm-based training. Despite } \\
\text { the introduction of a new apprenticeship programme, there has been } \\
\text { a considerable drop in the number of apprenticeship starts. }\end{array}$ & $\begin{array}{l}\text { Further increase public spending on training to develop digital skills of } \\
\text { low-skilled workers. } \\
\text { Better target the apprenticeship system to favour access of low-skilled } \\
\text { workers. Introduce individually targeted programmes for low-wage and low- } \\
\text { skilled workers to improve their lifelong learning opportunities. }\end{array}$ \\
\hline \multicolumn{2}{|c|}{ Enhance public sector efficiency } \\
\hline $\begin{array}{l}\text { The United Kingdom has set a strategy for further e-government } \\
\text { development. }\end{array}$ & $\begin{array}{l}\text { Take concrete actions, in particular regarding government procurement, to } \\
\text { implement the Government Digital Transformation Strategy and adopt a } \\
\text { portfolio of innovation activities and a cross-ministry approach. }\end{array}$ \\
\hline
\end{tabular}




\section{Bibliography}

Adalet McGowan, M., D. Andrews and V. Millot (2017), "The Walking Dead? Zombie Firms and Productivity Performance in OECD Countries", OECD Economics Department Working Papers, No. 1372, OECD Publishing, Paris.

Ahmad, N., J. Ribarsky and M. Reinsdorf (2017), "Can Potential Mismeasurement of the Digital Economy Explain the Post-Crisis Slowdown in GDP and Productivity Growth?", OECD Statistics Working Papers, No. 2017/09, OECD Publishing, Paris.

Appelt, S., et al. (2016), "R\&D Tax Incentives: Evidence on Design, Incidence and Impacts", OECD Science, Technology and Industry Policy Papers, No. 32, OECD Publishing, Paris.

Andrews, D., C. Criscuolo and P. Gal (2016), "The Best versus the Rest: The Global Productivity Slowdown, Divergence across Firms and the Role of Public Policy", OECD Productivity Working Papers, No. 5, OECD Publishing, Paris.

Andrews, D., G. Nicoletti and C. Timiliotis (2018), "Digital Technology Diffusion: A matter of Capabilities, Incentives or Both?", OECD Economics Department Working Papers, No. 1476, OECD Publishing, Paris.

Andrieu E., S. Jamet, L. Marcolin and M. Squicciarini (2019), "Occupational Transitions: The Cost of Moving to a "Safe Haven"" OECD Science, Technology and Industry Policy Papers, No. 61, OECD Publishing, Paris.

Anyadike-Danes, M. and M. Hart (2017), "Firm and Job Dynamics in the United Kingdom before, during and after the Global Financial Crisis: Getting in under the Hood", in Business Dynamics and Productivity, OECD Publishing, Paris.

Atkinson Review (2005), Final Report: Measurement of Government Output and Productivity for the National Accounts.

Bardalai A. (2019), Financial Services Productivity - a Regional Perspective, The CityUK blog.

Bailin Rivares, A., P. Gal, V. Millot and S. Sorbe, (2019), "Like it or Not? The Impact of Online Platforms on the Productivity of Incumbent Service," OECD Economics Department Working Papers, No. 1548, OECD Publishing, Paris.

Bajgar, M., G. Berlingieri, S. Calligaris, C. Criscuolo and J. Timmis (2019), "Industry Concentration in Europe and North America", OECD Productivity Working Papers, No. 18, OECD Publishing, Paris.

Barnett, A., A. Chiu, J. Franklin and M. Sebastia-Barriel (2014a), "The Productivity Puzzle: a Firm-Level Investigation into Employment Behaviour and Resource Allocation over the Crisis", Bank of England Working Paper, No. 495.

Barnett, A., S. Batten, A. Chiu, J. Franklin and M. Sebastian-Barriel (2014b), "The UK Productivity Puzzle", Bank of England Quarterly Bulletin, 2014 Q2.

Benato, A., S. Davies, F. Mariuzzo and P. Ormosi (2019), "Mergers and Innovation: Evidence from the Hard Disk Drive Market", Center for Competition Policy Working Paper, version 3.

BEIS (2018), Allocation of Funding for Research and Innovation 2017-21, August.

BIS (2012), "Leadership and Management in the UK: The Key to Sustainable Growth".

Bloom, N., M. Draca and J. Van Reenen (2016), "Trade Induced Technical Change? The Impact of Chinese Imports on Innovation, IT and Productivity", Review of Economic Studies 83, 87-117.

Bloom N. P. Bunn, S. Chen, P. Mizen, P. Smietanka and G. Thwaites (2019), The Impact of Brexit on UK Firms, NBER Working Paper No. 26218, September. 
Brooke M., O. Bush, R. Edwards, J. Ellis, B. Francis, R. Harimohan, K. Neiss and C. Siegert (2015), "Measuring the Macroeconomic Costs and Benefits of Higher UK bank Capital Requirements", Financial Stability Paper No. 35, December.

Bryson, A. and J. Forth (2015), "The UK's Productivity Puzzle”, IZA Discussion Paper No. 9097, June.

Byrne, D., J. Fernald and M. Reinsdorf, (2016), "Does the United States have a Productivity Slowdown or a Measurement Problem?", Brookings Paper on Economic Activity.

Calligaris, S., C. Criscuolo and L. Marcolin (2018), "Mark-ups in the Digital Era", OECD Science, Technology and Industry Working Papers, No. 2018/10, OECD Publishing, Paris.

Calvino, F. and C. Criscuolo (2019), "Business Dynamics and Digitalisation", OECD Science, Technology and Industry Policy Papers, $\mathrm{n}^{\circ}$ 62, OECD Publishing, Paris.

Center for Health Economics (2019), Productivity of the English National Health Service: 2016/17 update, CHE Research Paper 163.

CMA (2019), The CMA's Digital Market Strategy, June.

De Loecker, J., C. Fuss and J. Van Biesebroeck (2018), "Markup and Price Dynamics: Linking Micro to Macro," Working Paper Research, No. 357, National Bank of Belgium.

Department of Education (2020), Apprenticeship and Trainership: England 2020.

Digital Competition Expert Panel (2019), Unlocking Digital Competition.

Demmou, L., G. Franco and I. Stefanescu (2020), "Productivity and Finances: The Intangible Assets Channel - A Firm Level Analysis”, OECD Economics Department Working Papers, No. 1596, OECD Publishing, Paris.

Égert, B. and P. Gal (2017), "The Quantification of Structural Reforms in OECD Countries: A New Framework", OECD Journal: Economic Studies, Vol. 2016/1.

European Union and UK Government (2019), Revised Political Declaration, October.

Gal, P., et al. (2019), "Digitalisation and Productivity: In Search of the Holy Grail - Firm-Level Empirical Evidence from EU Countries", OECD Economics Department Working Papers, No. 1533, OECD Publishing, Paris.

Ghironi, F. and M. Melitz (2005), 'International Trade and Macroeconomic Dynamics with Heterogeneous Firms', Quarterly Journal of Economics, 120, 865-915.

Grassano, N. and M. Savona (2014), "Productivity in Services Twenty Years on. A Review of Conceptual and Measurement Issues and a Way Forward", SPRU Working Paper Series, SWPS 2014-01.

Griliches, Z. (1992), "The Search for R\&D Spillovers", Scandinavian Journal of Economics, 94, S29-47.

Grundke, R. et al. (2018), "Which Skills for the Digital Era? Returns to Skills Analysis", OECD Science, Technology and Industry Policy Papers, ${ }^{\circ}$ 2018/09, OECD Publishing, Paris.

Haldane, A. (2018), “The UK's Productivity Problem: Hub no Spokes”, Bank of England Speech.

Haldane, A. (2017), "Productivity Puzzles", Bank of England Speech.

Haskel, J. and S. Westlake (2017), Capitalism without Capital, Princeton University Press.

Haskel, J. and R. Sadun (2012), "Regulation and UK Retailing Productivity: Evidence from Microdata", Economica, 79: 425-448.

Hebous, S. and M. Ruf (2017), "Evaluating the Effects of ACE Systems on Multinational Debt Financing and Investment", Journal of Public Economics, Vol. 156, pp. 131-149. 
HM Government (2019), Regulations for the Fourth Revolution, June.

HM Revenue and Customs (2018), Research and Development Tax Credits Statistics, September 2018.

HMT (2018), Financing Growth on Innovative Firms: One-Year On, HM Treasury, Policy Paper.

HMT (2017) Financing Growth in Innovative Firms: Consultation Response, November.

Institute for Employment Studies (2016), Productivity in the Retail Sector: Challenges and Opportunities, Strategic Labour Market Intelligence Report.

Institute for Government (2018), Government Procurement: the Scale and Nature of Contracting in the UK, December.

IPO and British Business Bank (2018), Using Intellectual Property to Access Growth Funding.

Independent Panel (2019), Review of Post-18 Education and Funding.

Industrial Strategy Council (2020), Annual Report, February.

Kierzenkowski, R., G. Machlica and G. Fulop (2018), "The UK Productivity Puzzle through the Magnifying Glass: A Sectoral Perspective", OECD Economics Department Working Papers, No. 1496, OECD Publishing, Paris.

Kim, E.J., A. Mourougane and M. Baker (forthcoming), "What Drives Productivity in the United Kingdom and in Europe? Evidence from Sectoral and Firm-Level Data", OECD Economic Department Working Paper, OECD Publishing, Paris.

Langedijk, S., G. Nicodeme, A. Pagano and A. Rossi (2015), "Debt Bias in Corporate Income Taxation and the Costs of Banking Crises", CEPR Discussion Paper 10616.

LSE Growth Commission (2017), UK Growth a new Chapter, Centre for Economic Performance.

Mersch, Y. (2008), "Productivity in the Financial Services Sector", Opening remarks at the BCL-SUERF Conference on "Productivity in the Financial Services Sector", Luxembourg, 11-12 November.

Meloninna M., H. Miller and S. Tatomir (2018), "Business Investment, Cost of Capital and Uncertainty in the United Kingdom - Evidence from Firm-Level Analysis", Bank of England Staff Working Paper No. 717, March.

OECD (2020a), Economic Survey for the United Kingdom, OECD Publishing.

OECD (2020b), OECD Services Trade Restrictiveness Index: Policy Trends up to 2020.

OECD (2020c), "Productivity Gains from Teleworking in the Post COVID-19 Era : How Can Public Policies Make it Happen?", OECD Policy Brief, 7 September.

OECD (2020d), Services Trade in the United Kingdom and in the World Economy, forthcoming, OECD Publishing, Paris.

OECD (2020e), Stocktaking report on immediate public procurement and infrastructure responses to COVID-19.

OECD (2019a), OECD Compendium of Productivity Indicators 2019, OECD Publishing, Paris.

OECD (2019b), SME and Entrepreneurship Outlook, OECD Publishing, Paris.

OECD (2019c), Going Digital: Shaping Policies, Improving Lives, OECD Publishing, Paris.

OECD (2019d), "R\&D Tax Incentives UK note", OECD Publishing, Paris

OECD (2019e), Financing SMEs and Entrepreneurs 2019: An OECD Scoreboard, OECD Publishing, Paris. 
OECD (2019f) "Competition Concerns on Labour Markets", Background Note.

OECD (2019g), OECD Skills Outlook 2019: Thriving in a Digital World, OECD Publishing, Paris.

OECD (2018a), "Bridging the Rural Digital Divide", OECD Digital Economy Papers, No. 265, OECD Publishing, Paris.

OECD (2018b), "Enhanced SME Access to Diversified Financing Instruments", Discussion Paper, SME Ministerial Conference, OECD, Paris.

OECD (2018c), "Considering non Price Effects in Merger Control", Background Note by the Secretariat.

OECD (2018d), Apprenticeship in England, United Kingdom, OECD Reviews of Vocational Education and Training, OECD Publishing, Paris.

OECD (2017), Government at a Glance 2017, OECD Publishing, Paris.

OECD (2015), The Future of Productivity, OECD Publishing, Paris.

OECD (2013), 8th Meeting of the Advisory Expert Group on National Accounts, 29-31 May 2013.

ONS (2020), Technology intensity and homeworking in the UK, May.

ONS (2019a), Which Occupations are at Highest Risk of Being Automated?, 25 March,

ONS (2019b), Public Service Productivity: Total, UK, 2016.

ONS (2018a), Experimental Estimates of Investment in Intangible Assets in the UK: 2015, February.

ONS (2018b), Information and Communication Technology Intensity and Productivity, October,

ONS (2017), Understanding Firms in the Bottom $10 \%$ of the Labour Productivity Distribution in Great Britain: "the laggards", 2003 to 2015, October.

Page, M. (2018), "Support for Small Firms", House of Commons, Briefing Paper, No 7690, June.

Resolution Foundation (2019), "Apprenticeships System Favours Those Who Already Hold Skills", April.

Resolution Foundation (2018), "Is Everybody Concentrating? Recent Trends in Product and Labour Market Concentration in the UK", Torsten Bell and Dan Tomlinson, July.

Riley, R., A. Rincon-Aznar and L. Samek (2018), "Below the Aggregate: A Sectoral Account of the UK Productivity Puzzle", ESCoE Discussion Paper, 2018-06.

Riley, R, C. Rosazza Bondibene and G. Young (2014), "Productivity Dynamics in the Great Stagnation: Evidence from British Businesses", CFM Discussion Paper Series, 2014-7, Centre For Macroeconomics.

Sorbe, S., P. Gal and V. Millot (2018), "Can Productivity still Grow in Service-Based Economies?: Literature Overview and Preliminary Evidence from OECD countries", OECD Economics Department Working Papers, No. 1531, OECD Publishing, Paris.

Sorbe, S., et al. (2019), "Digital Dividend: Policies to Harness the Productivity Potential of Digital Technologies", OECD Economic Policy Papers, No. 26, OECD Publishing, Paris.

Syverson, C. (2017), "Challenges to Mismeasurement Explanations for the US Productivity Slowdown", Journal of Economic Perspectives, 31 (2): 165-86.

Taylor Review (2017), Good Work: the Taylor Review of Modern Working Practices, July,

Triplett, J.E. and B. Bosworth, (2003), "Productivity Measurement Issues in Services Industries:

"Baumol's disease" has been Cured", Economic Policy Review, (Sept), 23-33.

UKCES (2016), Investment in Training Survey 2015, Technical Report, Evidence Report 99, May. 
54 | ECO/WKP(2020)37

UNDP Global Centre for Public Service Excellence (2015), "Is the Private Sector more Efficient? A Cautionary Tale".

Ward, A., M. Zinni et P. Marianna (2018), "International Productivity Gaps: Are Labour Input Measures Comparable?", OECD Statistics Working Papers, No. 2018/12, OECD Publishing, Paris..

Wölfl, A. (2005), "The Service Economy in OECD Countries: OECD/Centre d'études prospectives et d'informations internationales (CEPII)", OECD Science, Technology and Industry Working Papers, No. 2005/03, OECD Publishing, Paris.

ZEW (2016), "The Effects of Tax Reforms to Address the Debt-Equity Bias on the Cost of Capital and on Effective Tax Rates", Taxation Papers, No. 65, Centre for European Economic Research, European Commission. 